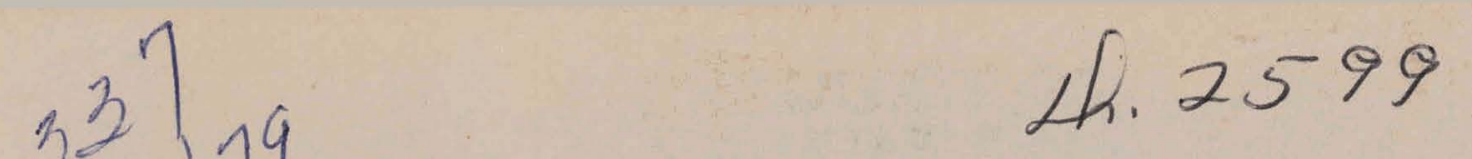

RHO-BWI-ST-1

\title{
Geophysical Logging and Hydrologic Testing of Deep Basalt Flows in the Rattlesnake Hills Well Number One
}

R. E. Gephart

P. A. Eddy

R. A. Deju

January 1979

Prepared for the United States

Department of Energy

Under Contract EY-77-C-06-1030

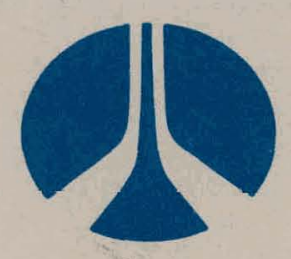

Rockwell International

Rockwell Hanford Operations

Energy Systems Group

Richland, WA 99352 


\section{DISCLAIMER}

This report was prepared as an account of work sponsored by an agency of the United States Government. Neither the United States Government nor any agency Thereof, nor any of their employees, makes any warranty, express or implied, or assumes any legal liability or responsibility for the accuracy, completeness, or usefulness of any information, apparatus, product, or process disclosed, or represents that its use would not infringe privately owned rights. Reference herein to any specific commercial product, process, or service by trade name, trademark, manufacturer, or otherwise does not necessarily constitute or imply its endorsement, recommendation, or favoring by the United States Government or any agency thereof. The views and opinions of authors expressed herein do not necessarily state or reflect those of the United States Government or any agency thereof. 


\section{DISCLAIMER}

Portions of this document may be illegible in electronic image products. Images are produced from the best available original document. 


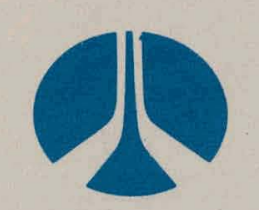

\title{
Rockwell International \\ Rockwell Hanford Operations \\ Energy Systems Group \\ Richland, WA 99352
}

\begin{abstract}
NOTICE
This Report was prepared as an account of work sponsored by the United States Government. Neither the United States nor the United States Department of Energy, nor any of their Employees, nor any of their Contractors, Subcontractors, or their Employees, makes any warranty, express or implied, or assumes any legal liability or responsibility for the accuracy, completeness, or usefulness of any in, formation, apparatus, product or process disclosed, or represents that its use would not infringe privately owned rights.
\end{abstract}

AVAILABLE FHUM I HE

NATIONAL TECHNICAL INFORMATION SERVICE

SPRINGFIELD, VA. 22161

PRICE: MICROFICHE: $\$ 3.00$

PAPER COPY: $\frac{\phi 9.50}{7,25}$ 


\author{
R. E. Gephart \\ Basait Hydrology Unit \\ Research Department \\ R. A. Deju \\ Program Director \\ Basalt Waste Isolation Program \\ Rockwell International \\ Rockwell Hanford Operations \\ Energy Systems Group. \\ Richland, Washington 99352
}

and

P. A. Eddy

Occupational and Environmental Safety Department

Pacific Northwest Laboratory

Richland, Washington $9935^{\circ} \mathrm{Z}$ 


\section{A B S T R ACT}

Geophysical logging and hydrologic testing were conducted in the Rattlesnake Hills Well Number One located along the western boundary of the Hanford Site in south-central Washington. Three-dimensional velocity, Seisviewer and caliper logging were completed across 2,000 feet of basalt rock within the Wanapum and Grande Ronde formations. Drillstem testing focused along a 250-foot interval of the Grande Ronde Formation.

Individual high- (22,7-2.9 grams por aubio centimete1") and lowdensity ( 2.3-2.6 groms per cubic centimeter) basalt zones within the Wanapum Formation are generally less than 50 feet thick. Within the estimated thickness of the Grande Ronde Formation, 85 percent of the low-density zones are less than 50 feet thick, compared to 55 percent of those of higher density. The Grande Ronde Formation has 13 high-density zones varying in thickness from 51 to 230 feet. Logging data suggest the thicknesses of low-density zones are independent of the thicknesses of the associated and underlying higher density columar basalts.

Eleven drillstem tests were conducted across selected intervals within the lirande Ronde Formation. Hydraulic conductivity values calculated for the low-density basalt zones ranged between $1.7 \times 10^{-7}$ and $3.8 \times 10^{-y}$ centimeters per second; those for high-density zones were between $1.1 \times 10^{-8}$ and.4.? $\times 10^{-9}$ centimeters per second. 
TABLE OF CONTENTS

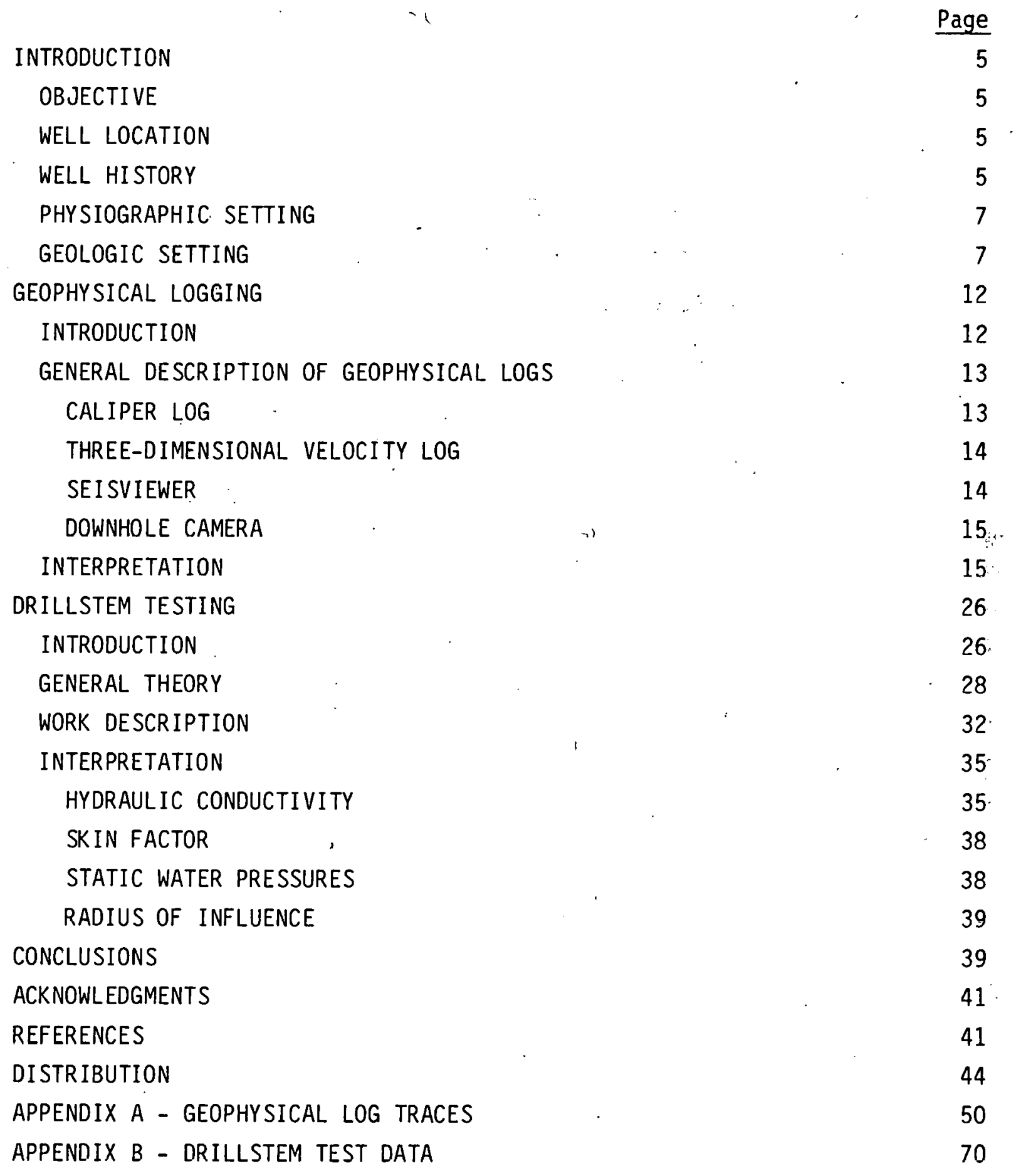


FIGURE 1

FIGURE 2

FIGURE 3

FIGURE 4

FIGURE 5

FIGURE 6

FIGURE 7

FIGURE 8

FIGURE 9

FIGURE 10

FIGURE 11

FIGURE 12

FIGURE 13
MAP OF HANFORD SITE AND SURROUNDING AREA SHOWING LOCATION OF TEST WELL

OUTLINE OF THE COLUMBIA RIVER BASALT GROUP

8

STRATIGRAPHY OF THE PASCO BASIN

9

SCHEMATIC OF WELL RSH-1

11

THICKNESS OF LOW-DENSITY ZONES WITHIN THE COLUMBIA RIVER BASALT GROUP PENETRATED BY WELL RSH-1

THICKNESS OF HIGH-DENSITY ZONES WITHIN THE COLUMBIA RIVER BASALT GROUP PENETRATED BY WELL RSH-1

HISTOGRAM SHOWING THE FREQUENCY OF LOW-DENSITY ZONE THICKNESSES WITHIN THE GRANDE RONDE FORMATION

HISTOGRAM SHOWING THE FREQUENCY OF HIGH-DENSITY ZONE THICKNESSES WITHIN THE GRANDE RONDE FORMATION COLUMBIA RIVER BASALT GROUP

GEOPHYSICAL LOG TRACES ACROSS
$2 ; 860$ FEET BELOW GROUND LEVEL

\section{LIST OF TABLES}

TABLE I

DEPTHS TO SPECIFIC BASALT INTERVALS LATER HYDROLOGICALLY TESTED

TABLE II

LISTING OF ALL DRILLSTEM TESTS CONDUCTED

TABLE III

VALUES OF HYDRAULIC CONDUCTIVITY AND SKIN FACTOR

36

TABLE IV 
INTRODUCTION

\section{OBJECTIVE}

Geophysical logging and hydrologic testing of the Rattlesnake Hills Well Number One (RSH-1) were conducted to study the geohydrologic characteristics of selected portions of the Grande Ronde Formation of the Columbia River Basalt Group. Well RSH-1 is one of several boreholes in and around the Hanford Site from which downhole data have been collected on the Columbia River Basalt Group.

\section{WELL LOCATION}

Well RSH-1 is located west of the Hanford Site about 15 miles north of the town of Prosser, Washington and 12 miles northeast of Sunnyside; Washington (Figure 1). The exact location is 300 feet north and 300 feet west of the southeast corner of Section 15, Township 11 North, Range 24 East of the Willamette Meridian. The land surface elevation is 2,889 feet above mean sea level. Travel to RSH-1 is by road from the south via the towns of Prosser and Grandview. Because the well is located on private property, access was arranged through a lease agreement with the owner, Mr. H. G. Anderson.

\section{WELL HISTORY}

Well RSH-1 was drilled in 1957 and 1958 for the Standard $0 i 1$ Company of California by Miracle and Wooster Drilling Company of Vernal, Utah. The well is 10,655 feet deep and was drilled to accept 18-1/2-inch casing for the first 22 feet, and 13-3/8-inch casing to 603 feet (a) 1 further depth references use ground level as the common datum plane). A 9-7/8-inch open hole was drilled from 603 feet to 8,418 feet and a 9-inch open hole from 8,418 feet to 10,655 feet. In April 1958, a cement plug was installed from 540 feet to 690 feet and the well was abandoned. In May 1967, Battelle-Northwest contracted Taylor Drilling Company of Chehalis, Washington to clean the well. The original plug was drilled out and drilling fluid was recirculated to 9,157 feet. The well was then geophysically logged, side-hole samples were taken by Schlumberger Well Services Corporation of West Sacramento, California, and 7 drillstem tests were conducted by Cook Testers of Long Beach, California. The well was then replugged between 500 and 658 feet. The results of this work were documented. (1) 


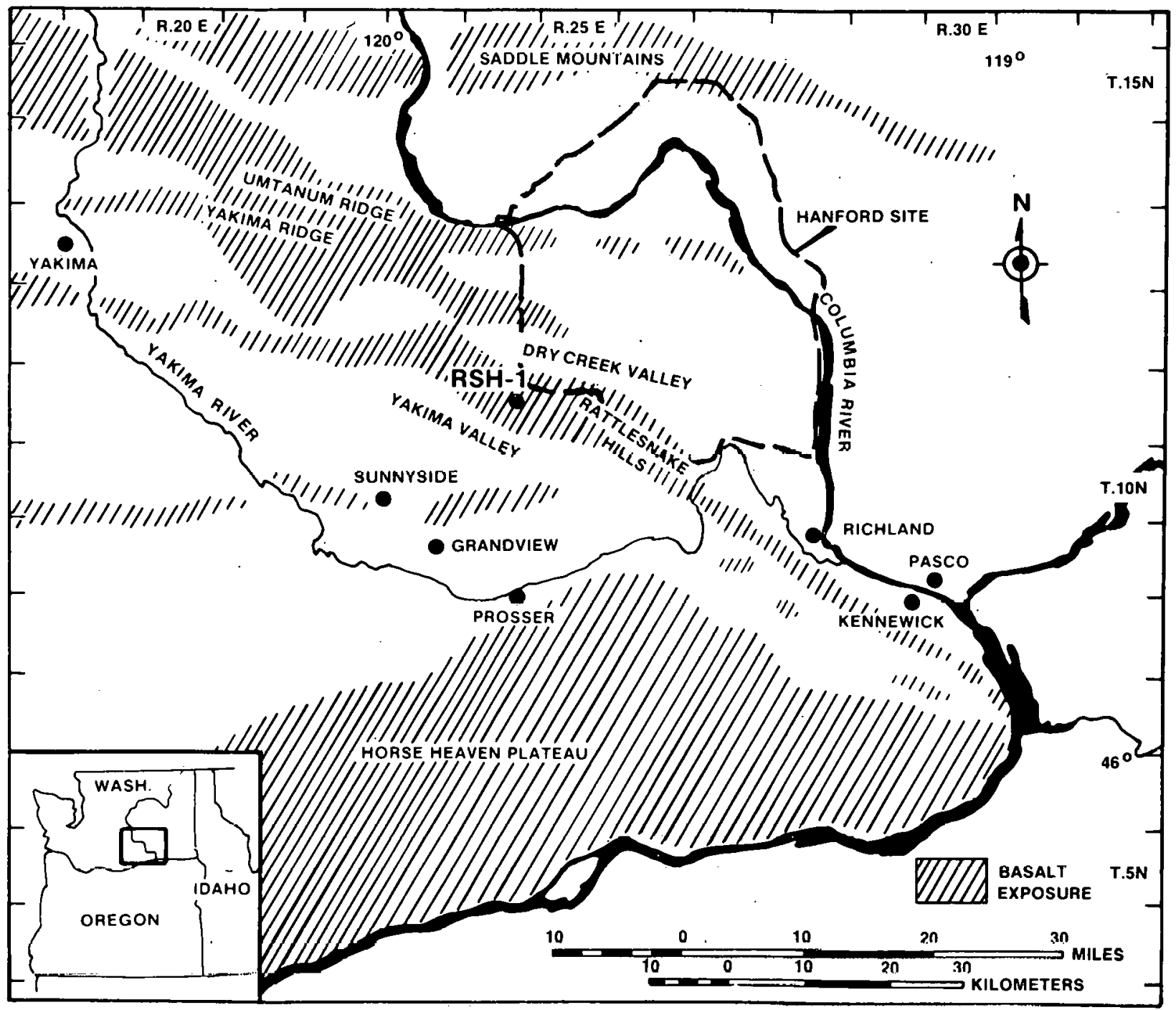

V7812-1.1

FIGURE 1

MAP OF HANFORD SITE AND SURROUNDING AREA SHOWING LOCATION OF TEST WELL 


\section{PHYSIOGRAPHIC SETTING}

The well is located near the anticlinal axis of the Rattlesnake Hills, which is an east-west-trending basalt ridge rising 3,000 feet above the valley floor. This ridge separates the Yakima Valley from the Dry Creek Valley. The ridge extends eastward from the Cascade Mountains to the Yakima River south of Yakima, Washington as Ahtanum Ridge. Farther eastward, it is called Rattlesnake Hills before passing into a series of doubly plunging anticlines. The total.length of the ridge is about 90 miles. The north flank is relatively steep; however, the south flank in which RSH-1 is located has a gentler slope.

\section{GEOLOGIC SETTING}

The Columbia River Basalt Group forms a layered rock mass covering approximately 60,000 square miles in parts of Washington, Oregon and Idaho to an average thickness of 1,600 feet (Figure 2). (') This accumulation of basalt resulted from the repeated eruption of molten rock. from middle Miocene, approximately 16 million years before present, through early Miocene, approximately 8 million years before present. (3-6) An estimated 99 percent of the basalts in the Columbia River Basalt Group were emplaced during a 3-million-year volcanic pulse occurring 16 to 13 million years before present. (7)

The Pasco Basin is one of several structural basins underlain by the Columbia River Basalt Group (Figure 2). However, the Pasco Basin is unique in that it contains a great accumulation of basalt having a minimum thickness of about 5,000 feet. ${ }^{(8-10)}$ We 11 RSH-1 is the deepest exploratory hole yet completed in the Pasco Basin. The basal.t apparently overlies a series of older volcanic rocks of Eocene to 01 igocene age. $(1,11)$

- The stratigraphic nomenclature of the Columbia River Basalt Group has recently been revised (Figure 3 ). In this revision, the group has been subdivided into three formations: the Saddle Mountains; the Wanapum; and the Grande Ronde which collectively constitute the Yakima Basalt Subgroup. Previously, these formations were known as the Upper, Middle and Lower Yakima basalts, respectively. These formations are, in turn, divided into various members and flows.

The subsurface stratigraphy of the Pasco Bas in is reasonably well understood. It has been developed by correlating basalt strata between surface outcrops and core holes using petrographic, geochemical and 


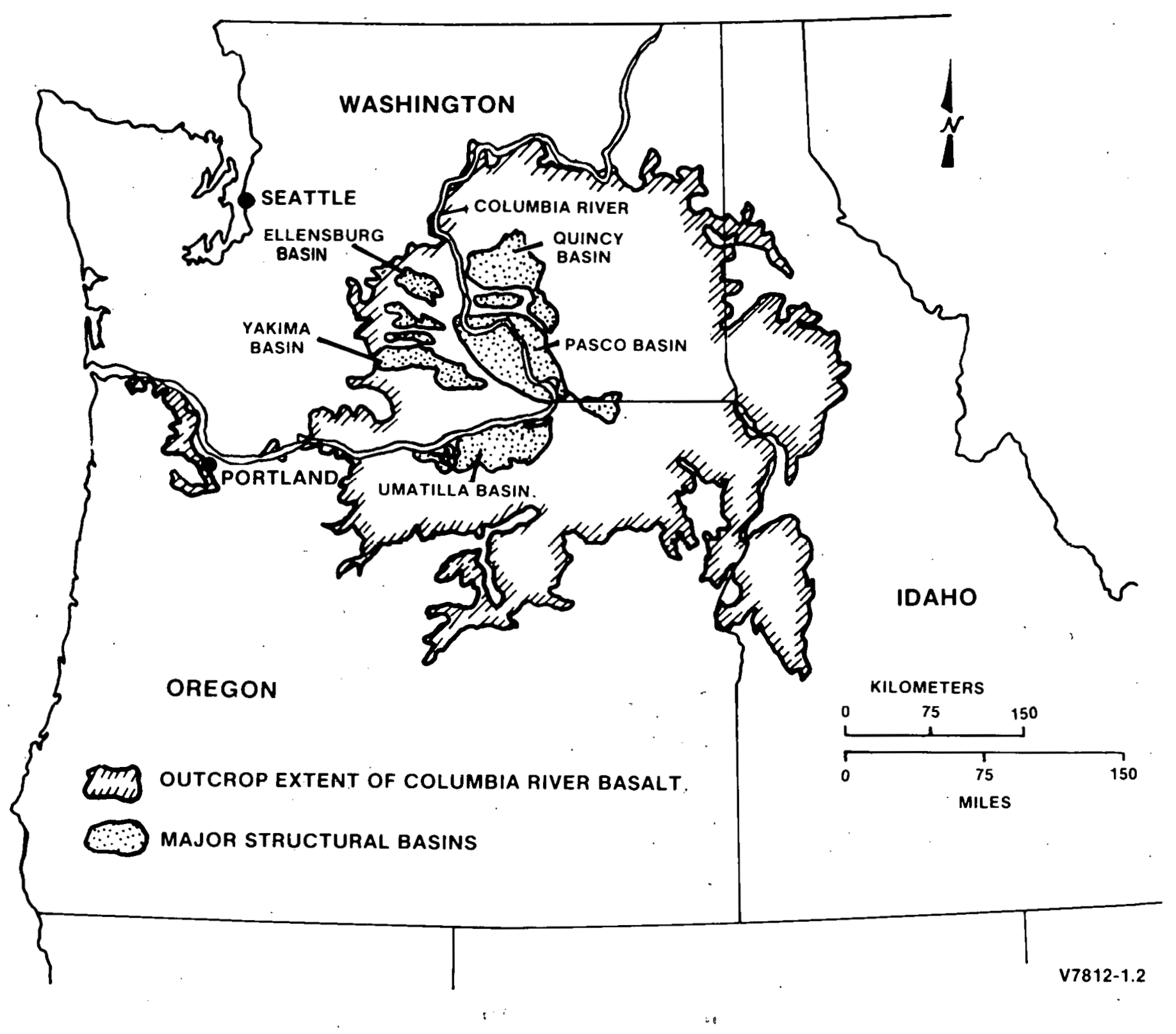

FIGURE 2

OUTLINE OF THE COLUMBIA RIVER BASALT GROUP 


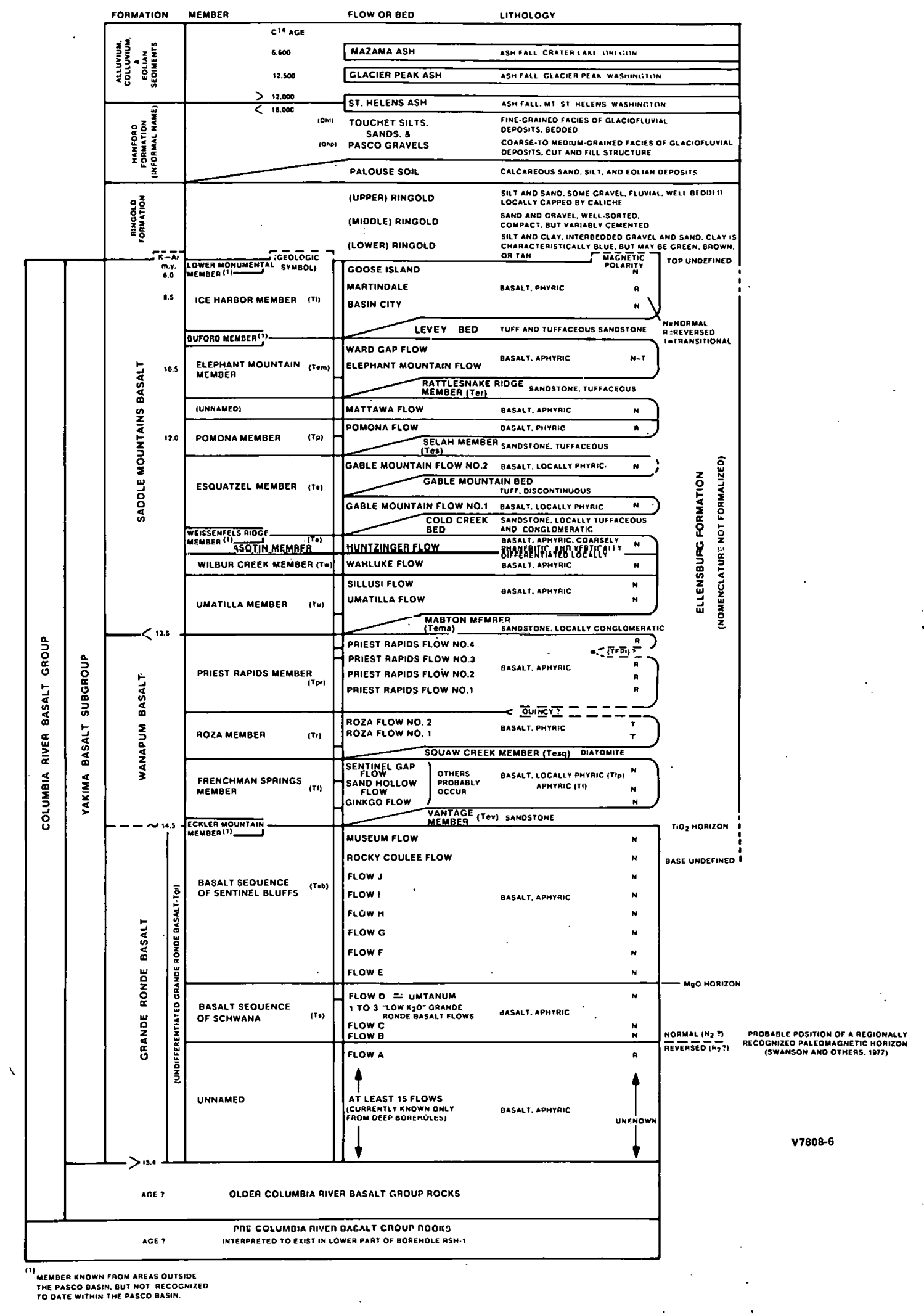

FIGURE 3

STRATIGRAPHY OF THE PASCO BASIN 
geophysical data. Well RSH-1 was drilled through the Columbia River Basalt Group and into older rocks which were described as andesitic basalt. (1) The Saddle Mountains Formation forms the upper 475 feet of basalt section penetrated by RSH-1. The Wanapum Formation lies between 475 and 1,670 feet and is separated from the Grande Ronde Formation by a thin (less than 20 feet) section of Vantage Sandstone. The Grande Ronde Formation extends from a depth of 1,690 feet to approximately 5,000 feet (Figure 4). The exact depth of this lower boundary is still a subject of study.

Interpretations of deep tectonic structures within and beneath the Columbia River Basalt Group have been made using geologic, seismic, gravity, aeromagnetic and resistivity studies. (12-19) The Columbia River Basalt Group thins toward the edges of the basin, resting unconformably on Mesozoic granitic rocks of the Okanogan Highlands to the north, pre-Cambrian to Mesozoic rocks in the Rocky Mountains to the east and mainly on folded Tertiary formations in the Blue Mountains and Cascade Mountains to the south and west. $(19,20)$ West-to-northwesttrending anticlinal ridges, such as the Rattlesnake Hills, developed above the floor of the aggrading basin during the waning stages of the basalt outpourings. (19) Synclinal basins formed between these anticlines. The Yakima and Dry Creek valleys are two of these synclines.

Columnar joints are the most common intraflow structures with in individual basalt flows. These formed from the cooling and shrinking of the original molten rock mass. Although the jointing shows considerable variability, both within and between flows, a typical flow usually has:

(1) A lower zone (the colonnade), generally 25 to 50 percent of the thickness of the entire flow and consisting of nearly symmetrical columnar joints that define hexagonal columns oriented perpendicular to the flow top;

(2) An upper zone (the entablature), generally 50 to 75 percent of the thickness of the flow and consisting of a more irregular jointing pattern where columnar joints, if present, are less distinct than in the colonnade; and

(3) A vesicular and rubbly flow top making up 10 to 30 percent of the flow unit. 
BOREHOLE INFORMATION

3

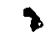

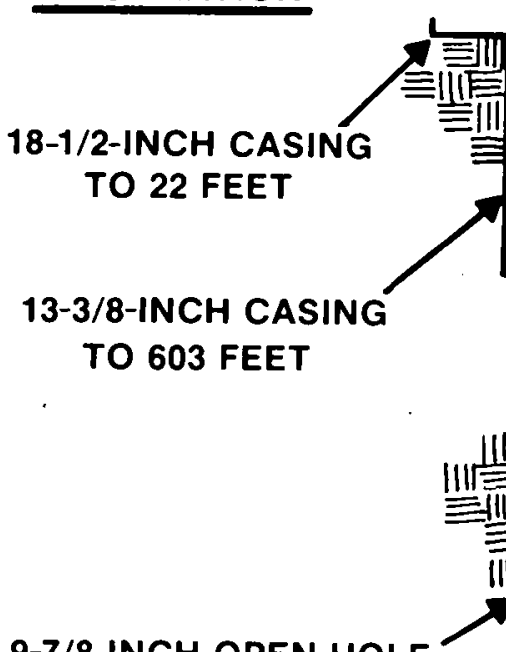
TO 8,418 FEET AND A 9-INCH OPEN HOLE TU IUIAL DEPTH

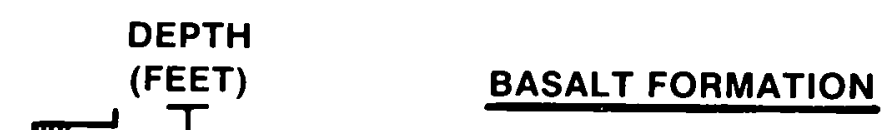

SADDLE MOUNTAINS

WANAPUM

(475)

GRANDE RONDE

V7812-1.8

PRE-GRANDE RONDE BASALT ROCKS

10,655 TOTAL DEPTH

$$
\text { V7812-1.8 }
$$

FIGURE 4

SCHEMATIC OF WELL RSH- 1 
Most flows also have a thin broken zone a few inches thick at the base. Some flow tops, particularly in the Saddle Mountains Formation, are capped by a thin sedimentary layer. Cooling joints are frequently filled with secondary minerals such as zeolites, amorphous iron-rich silicates and ferro-magnesium clays. (21)

Whole rock chemical analyses are needed to properly identify most stratigraphic locations and basalt flows. Downhole geophysical information alone is not sufficient. Since individual flow identification is not available for all the basalts penetrated by RSH-1, more general phrases than interflow or columnar basalt are used within this report. "Low-density zone, basalt or section" are used to refer to those intervals having low bulk densities ( 2.3 to 2.6 grams per cubic centimeter), long acoustic transit times and frequent borehole breakouts. These zones normally correspond to flow tops or interflows. In like manner, the phrase "high-density zone, basalt or section" or "denser basalts" is used to denote those intervals having high bulk densities ( 2.7 to 2.9 grams per cubic centimeter), short acoustic transit times and few, if any, borehole breakouts. Such intervals normally represent the colonnade and entablature portion of a basalt flow. The above density ranges have been determined for Columbia River Basalt using a downhole gravity meter survey. (22)

\section{GEOPHYSICAL LOGGING}

\section{INTRODUCTION}

Beginning April 13, 1977, the Birdwell Division of Raytheon Company, Tulsa, Oklahoma, conducted caliper, three-dimensional velocity and Seisviewer geophysical logging through the interval 1,000 feet to 2,860 feet below ground level. Logging was completed April 21, 1977. This work supplemented information obtained from earlier logging by other researchers. (1) Reproductions of these new logs are contained in Appendix . A.

In addition to the above three logs, a downhole camera was used to take oriented photographs of the borehole; however, poor photographs were obtained because of the water's turbidity. The results were of no interpretive value and are not included in this report. 
Variations in log responses reflect minor changes in borehole width and in the rock's fracturing pattern. The three logs mentioned above can provide information as to:

(1) Individual basalt flow thicknesses;

(2) Variations in the thicknesses of high- and low-density basalt zones;

(3) Areas of drilling mud cake buildup; and

(4) Borehole size changes.

These data are important in the interpretation of the response of the rock to fluid injection and in minimizing or eliminating water leakage around the inflatable packers used during drillstem testing.

The geophysical log responses reflect only those rock characteristics within the immediate vicinity of the borehole. These features may or may not be representative of the entire rock mass. However, since similar $\log$ reponses have been observed in other boreholes on the Hanford Site, it is assumed that these responses are generally representative of the formations penetrated.

GENERAL DESCRIPTION OF GEOPHYSICAL LOGS

Caliper Log

The caliper log gives a trace of the diameter and geometry of the borehole. This trace delineates breakouts, particularly in high-porosity zones where vesicular and rubbly rock exist, areas of possible mud cake buildup and other information such as roundness and smoothness of the borehole walls. This log assists in identifying those downhole intervals of smooth gauge hole in which packers may be set with a degree of confidence against leakage.

The caliper device used was a Birdwell Model CA6. This tool has six arms which operate in pairs. Three traces which represent the arms opposite each other are shown on the caliper log contained in Appendix A. Increased borehole diameters are shown as a trace flexure toward the right side. The fourth trace is a computed average of the three paired traces. The arms are capable of detecting one-quarter-of-an-inch variation in the borehole size. The arms extend and retract as they "feel" the face of the borehole and an electrical signal is transmitted to the surface where it is converted to a trace on the chart paper. 


\section{Three-Dimensional Velocity Log}

The three-dimensional velocity log was used to detect discontinuities within the basalt flows. These changes may result from variations in the intensity of jointing or in the occurrence of vesicles. This $\log$ is sometimes capable of detecting jointing variations within the dense columnar portion of a basalt flow. Such fine detail is not normally revealed using other geophysical tools. The tool consists of a series of acoustic signal transmitters and receivers which measure the transit time for specific acoustic waves to travel through the surrounding rock mass.

For use in RSH-1, the transmitting and receiving transducers were run using both 3-foot and 6-foot spacings. The 6-foot spacing run is contained in Appendix A. A signal was then pulsed at the rate of 20 cycles per second. The pressure waves received were converted into electrical signals and transmitted to the surface recording equipment.

The acoustic signals received consisted of a series of alternating voltages which varied with time. These voltages are converted to a light signal of varying intensity. This light is photographed as a horizontal line. The black and dark gray lines represent high positive voltages, the white tones high negative voltages and the lighter. gray tones intermediate values. (23) Successively exposed lines are stacked one atop the other, as shown on the three-dimensional velocity log in Appendix A. Because the lines have a measurable thickness and successive signals are recorded approximately every inch of borehole depth, the light and dark strips produce continuous longitudinal stripes. Variations in the porosity or fracture intensity of a rock formation are shown as rapid shifts in the acoustic travel times. Most of the leftward shifts shown on the three-dimensional velocity log result from long acoustic transit times across low-density (high-porosity) vesicular and rubble zones. Those downhole intervals showing evenly spaced dark and light bands represent the denser portions (entablature and colonnade) of a basalt flow.

\section{Seisviewer}

This geophysical tool produces an acoustic picture of the borehole wall useful for identifying and viewing joints, vugs, washouts and areas of mud cake buildup. The unit consists of a scanner-transducer and a 
flux gate magnetometer. A transducer in a rotating scanner emits a pulsed acoustic signal which travels through the borehole fluid and reflects back to a receiving transducer. The resultant image is transmitted to the surface where it is photographed from an oscilloscope display. The image is formed from a series of horizontal lines composed of closely spaced dots of varying intensity. The amount of energy reflected back is a function of the physical characteristics of the borehole wall. Irregularities reduce the strength of the signals displayed. The weak (low-amplitude) signals appear as dark areas and the strong (high-amplitude) signals are represented by a light-colored area. Gray spots are intermediate values. Because of the high density of dots making up the final image, the Seisviewer log can delineate very small features such as individual joints and vesicles.

The magnetometer in the tool permits the acoustic signal to start only when the transducer is pointed toward magnetic north (remanent magnetism in the basalt may interfere with tool orientation). This allows the entire borehole wall to be scanned, resulting in a direct and descriptive reproduction of the borehole as if it were sliced along a single line and opened flat.

Reproductions of oriented and non-oriented Seisviewer logs are contained in Appendix A.

\section{Downhole Camera}

The borehole camera contained a 16-millimeter film magazine and a high-intensity light source. Pictures were taken using a wide-angle lens pointed down the well. A magnetic compass mounted below the lens oriented each picture.

High-resolution photography is not possible unless the borehole is full of very clear water. The photographs taken in RSH-1 were of poor quality because the borehole fluid was discolored with suspended matter.

\section{INTERPRETATION}

Geophysical logs were examined specifically for:

(1) Identifying any variability in low- and high-density zone thicknesses;

(2) Locating specific intervals for setting inflatable packers; and

(3) Detecting any hole deterioration that had occurred since RSH-1 was logged 10 years earlier. 
In addition, the logs supplied supplemental data not acquired in a previous study. (1)

Ninety-two basalt flows and 89 interflow zones lying between the depths of 1,000 feet and 10,000 feet were identified from studies reported in Reference 1. The researchers hypothesized that the Columbia River Basalt Group terminated at about the 5,000-foot depth in RSH-1; below this depth, andesitic rocks were said to exist.

The gamma-gamma $\log ^{(1)}$ was re-examined to identify the major lowand high-density zones present within the Columbia River Basalt Group. This $\log$ is well suited for delineating lower density flow tops from the higher density basalt columns found in the entablature and colonnade portion of a flow. The specific intent of the re-examination was to determine if any discernible variation existed in the thicknesses of these individual density zones. The zero or base-line measurement point for the $\log$ was the top of the 13-1/2-foot boom used to lower the geophysical equipment into the hole. Since all geophysical logs conducted for this study and reported in Appendix $A$ used ground level as the zero datum, comparable depths will differ by 13-1/2 feet between the two logging suites.

Figures 5 and 6 are plots of the thickness of low- and high-density zones, respectively, as a function of depth through the Columbia River Basalt Group exposed in RSH-1. Geophysical log responses were available opposite the Wanapum and Grande Ronde formations. The Saddle Mountains Formation was not logged. To eliminate the influence of hole breakouts and of small nondescript logging responses, on ly intraflow zones greater than 10 feet thick were plotted.

Within the 1,070 feet of Wanapum Formation logged, the low- and high-density basalt zones are generally less than 40 feet thick. The notable exceptions are 2 thick dense sections lying 740 to 870 and 1,440 to 1,590 feet below ground level, respectively (Figure 6). Both Figures 5 and 6 show only small variations in the thickness of low- and highdensity zones within the Wanapum Formation.

The remaining $\pm 3,300$ feet of the Columbia River Basalt Group lie with in the Grande Ronde Formation. Here, a much wider distribution of high-density zone thicknesses occurs compared to those of lower density. These distributions are shown in Figures 5 and 6 and as histograms in 


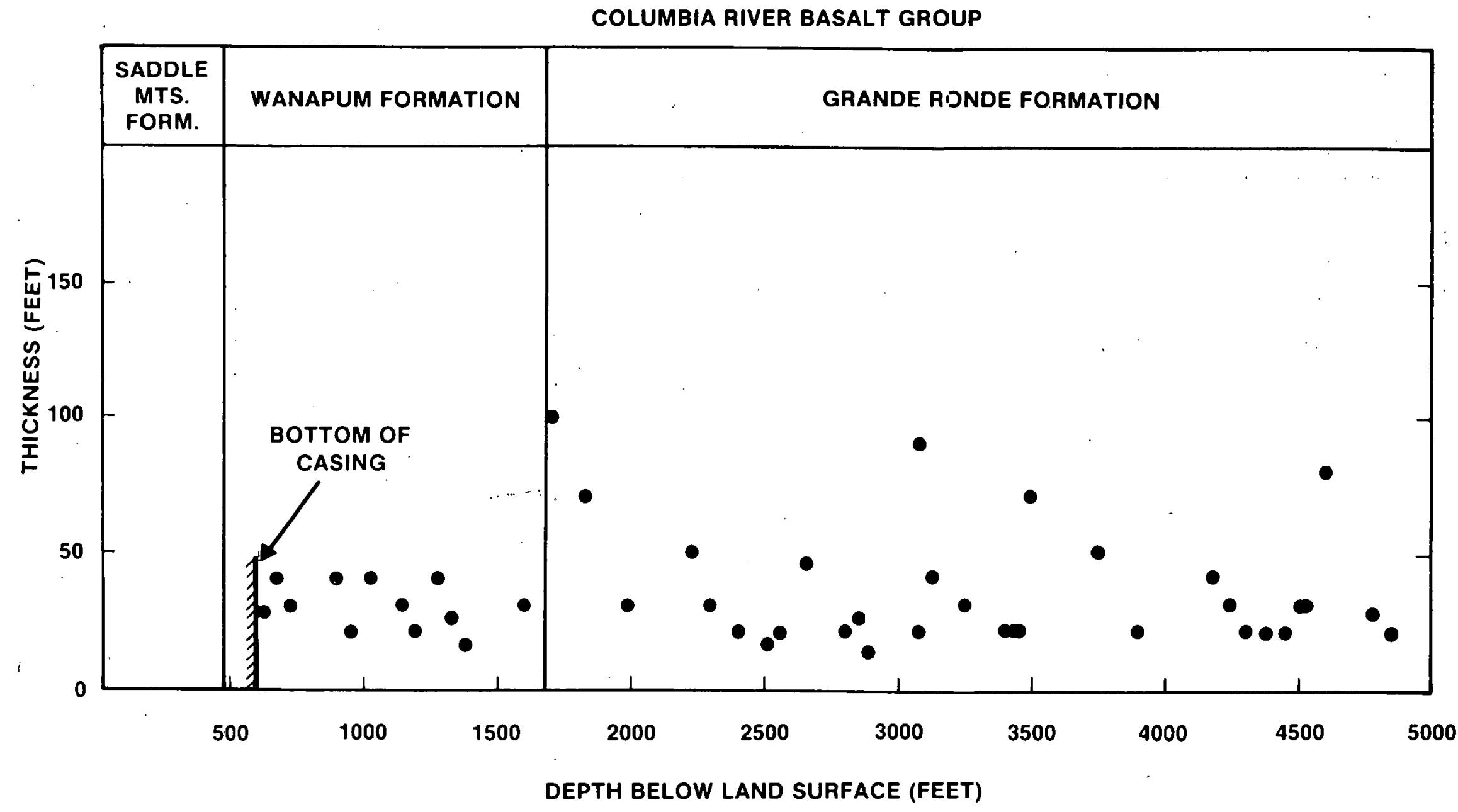

V7812-1.3

FIGURE $5: \therefore$

종
1
0
0
1
$\vdots$
$\vdots$
1

THICKNESS OF LOW-DENSITY ZONES WITHIN THE COLUMBIA RIVER BASALT GROUP PENETRATED BY WELL RSH-1 
COLUMBIA RIVER BASALT GROUP

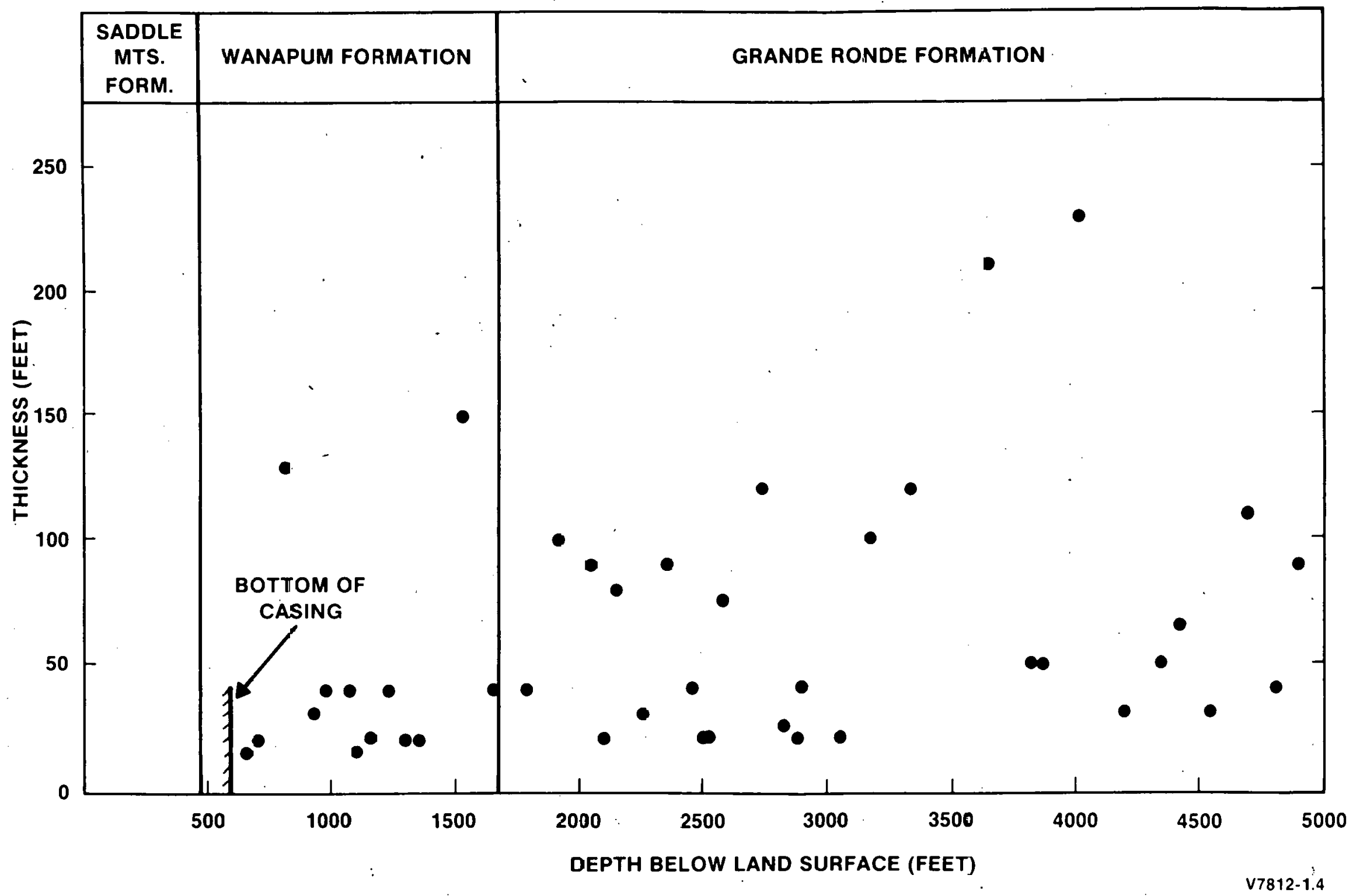

FIGURE 6

THICKNESS OF HIGH-DENSITY ZONES WITHIN THE COLUMBIA RIVER BASALT GROUP PENETRATED BY WELL RSH- 1 
Figures 7 and 8 . These last' two figures give the distribution of lowand high-density zone thicknesses as divided into 25-foot thick slabs. The first slab begins at a thickness of 11 feet because, as noted earlier, all intervals less than 10 feet thick were omitted from consideration.

Figure 7 reveals that 85 percent of the Grande Ronde low-density zones ( 28 of 33 points) are less than 50 feet thick. This compares to only 55 percent of equivalently thick dense basalt in Figure 8 . The remaining 15 percent of the low-density zones in Figure 7 are 51 to 100 feet thick. The remaining 45 percent of the high-density basalt, however, varies in thickness from 51 to 230 feet. Of particular significance are 5 dense sections greater than 100 feet thick (Figure 8 ). These 1 ie between the depths of $2,675-2,795,3,270-3,390,3,535-3,740$, $3,910-4,140$ and 4,650-4,760 feet (Figure 6). The uppermost of these 5 intervals corresponds to a section called the Umtanum basalt unit. Drillstem tests were later performed across this unit.

Only one low-density zone making up part of the Grande Ronde Formation is 100 or more feet thick. This zone includes the Vantage Sandstone of the Ellensburg Formation and forms the contact between the Wanapum and Grande Ronde formations. It is 1,670 to 1,770 feet below ground level. Below this, 4 other low-density zones are 51 to 99 feet thick.

Figures 5 and 6 reveal no discernible variation or specific trends in the thickening or thinning of either the low- or high-density zones with increased depth through the Grande Ronde Formation. What is evident, however, is a much wider distribution in the thicknesses of the denser basalts compared to those of low density; this is quite obvious in Figures 7 and 8.

Periodic thickness changes of the low- and high-density zones appear in Figures 5 and 6 . Figure 9 was drafted to more closely examine this phenomenon. Each 200-foot interval of the gamma-gamma log(1) was divided into its contributing amount of low- and high-density basalt. The results were then plotted as a function of depth (of course, the two traces are mirror images); notice the rhythmic pattern to the thicknesses of the denser basalts. For example, the maximum thicknesses of the denser basalts are centered at the depths of $900,1,500,2,100,2,700$ 


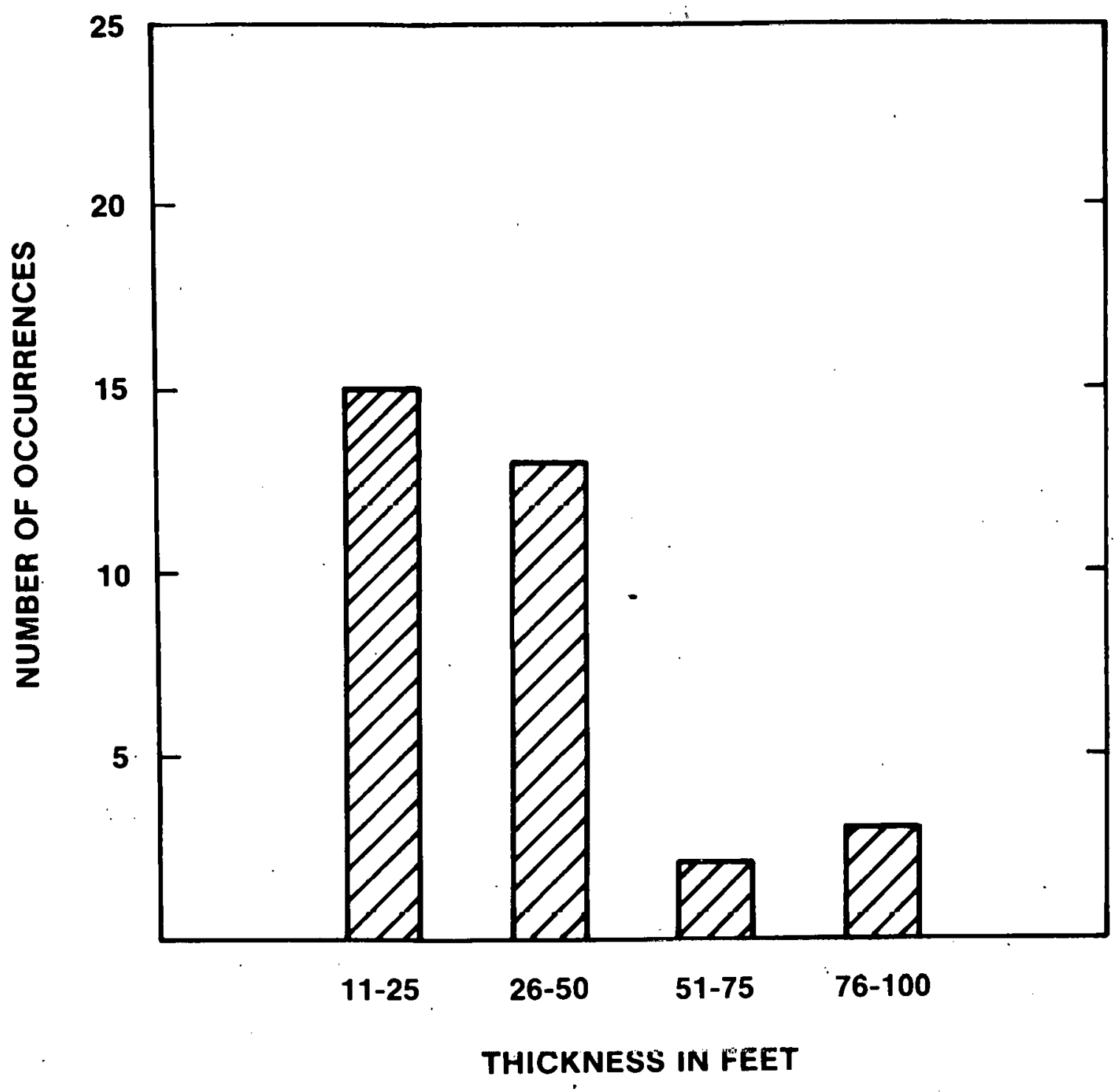

V7812-1.7

\section{FIGURE 7}

HISTOGRAM SHOWING THE FREQUENCY OF LOW-DENSITY ZONE THICKNESSES WITHIN THE GRANDE RONDE FORMATION 


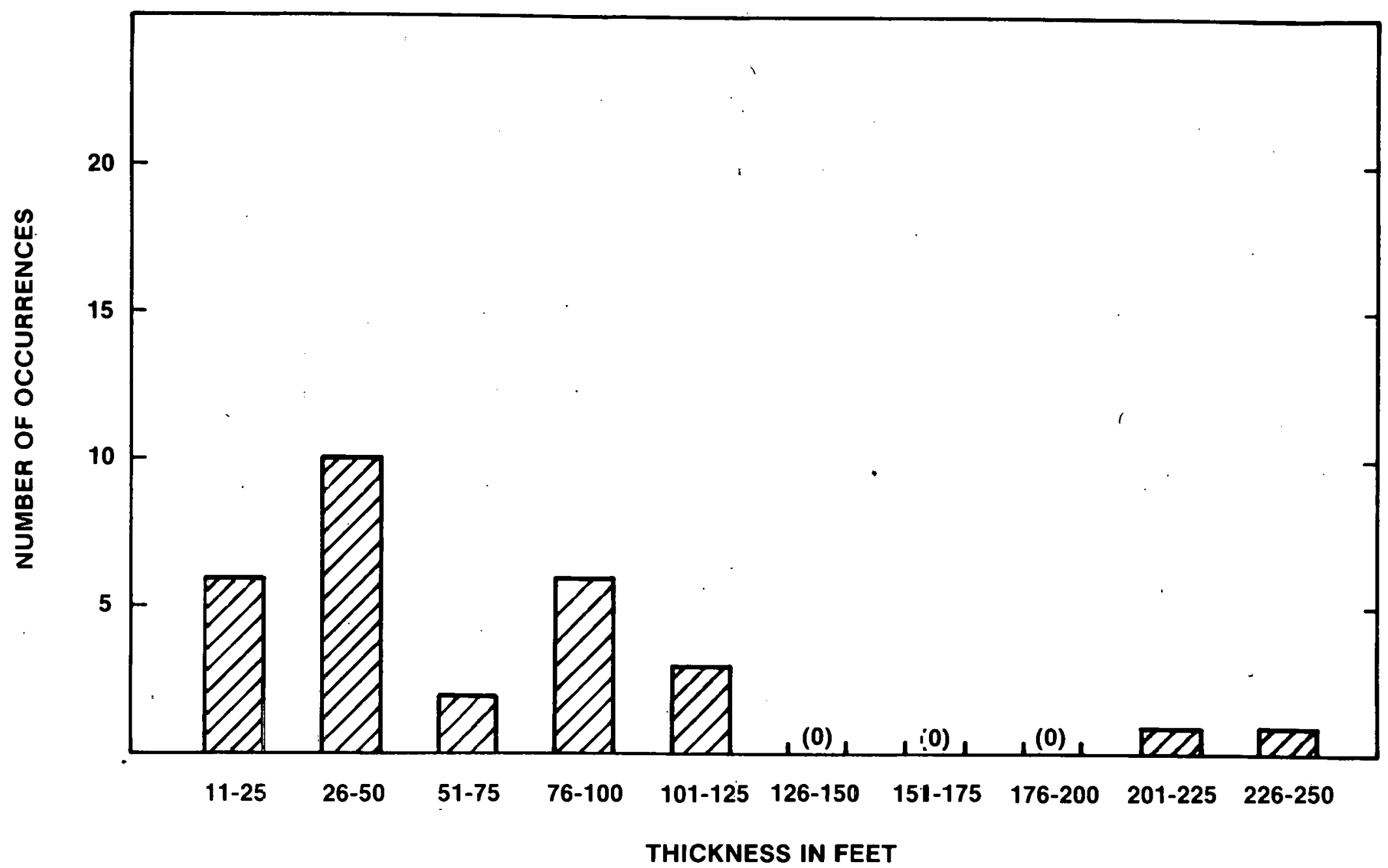

FIGURE 8

V7812-1.6

HISTOGRAM SHOWING THE FREQUENCY OF HIGH-DENSITY ZONE

THICKNESSES WITHIN THE GRANDE RONDE FORMATION 


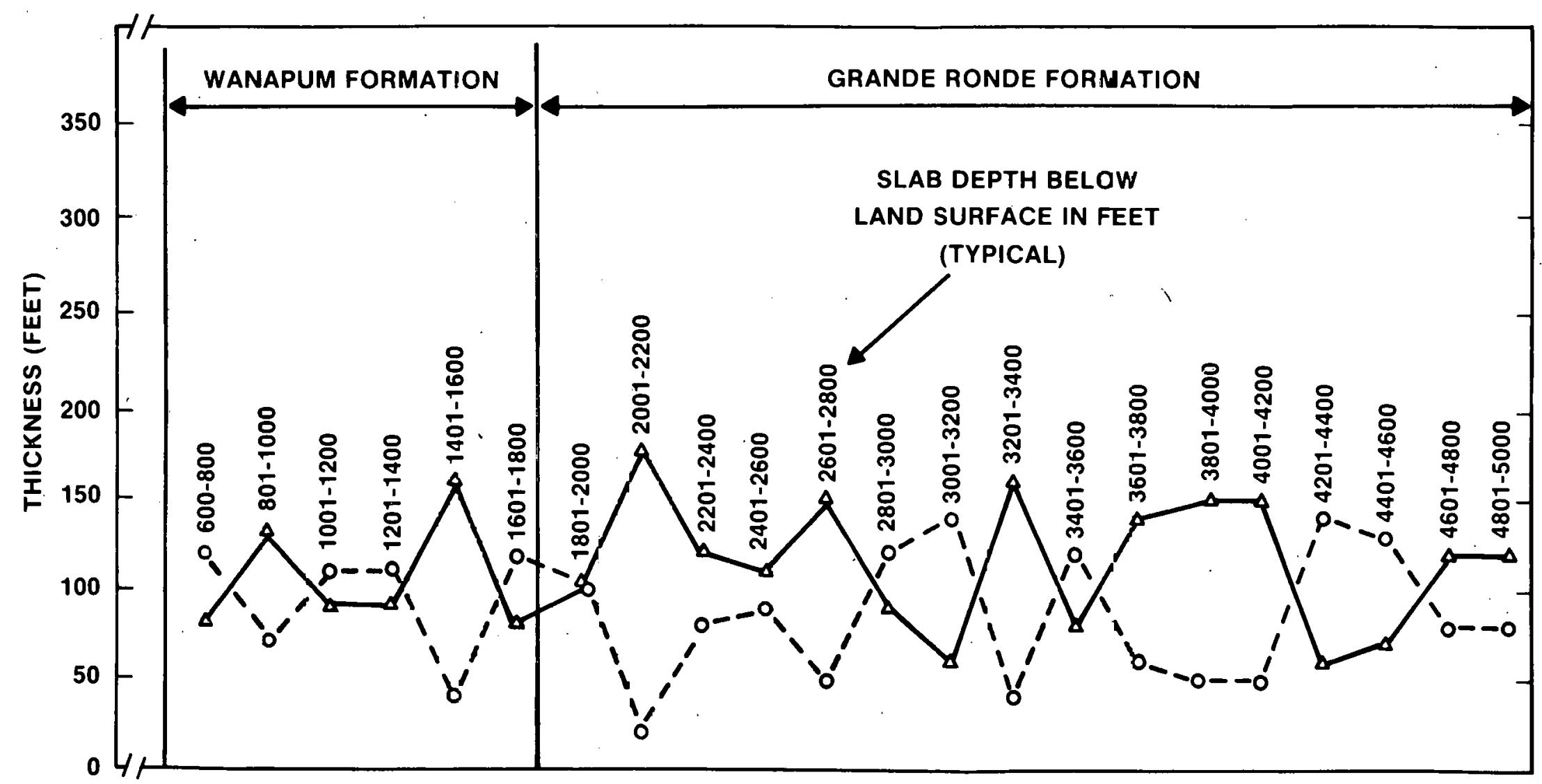

- LOW DENSITY

$\triangle H I G H$ DENSITY

v7812-1.5

FIGURE 9

VARIATION OF ZONE DENSITY THICKNESSES WITHIN THE COLUMBIA RIVER BASALT GROUP 
$3,300,3,900$ and 4,700 feet. Except for the last footage, each of these peaks is separated by about 600 vertical feet; thinner slabs would show some pattern variation. Thus, an apparent episodic physical thickening and thinning of flows occurred at the RSH-1 site... It was reported that below the depth of 5,000 feet individual basalt flows and interflow zones thickened and their geophysical log responses became more erratic. (1) This evidence suggests that the basalt or basaltic-like rock below 5,000 feet has had a distinct petrogenetic origin compared to the upper rock section now assigned to the Columbia River. Basalt Group.

The second task of downhole geophysics was to identify specific horizons for later hydrologic testing. The search centered on the Grande Ronde Formation above the cement plug lying at 2,860 feet.

The Seisviewer and three-dimensional velocity logs were run across the 1,000- to 2,860-foot depths. The caliper log trace was taken from ground level to the 2,860-foot depth (reproductions of these logs are contained in Appendix A; refer to Figure 4 when identifying specific formations). These logs indicate RSH-1 penetrates about 25 basalt flows between the depths of 600 and 2,860 feet. Individual flow thicknesses varied from a few tens of feet to 250 feet. The exact number of flows drilled cannot be identified solely upon geophysical log responses; trace element chemistry must be performed on actual rock samples.

The low-density zones consisting of vesicular or rubbly basalt are characterized by high porosities, long acoustic transit times and frequent borehole breakouts. The high-density sections of columnar basalt have low porosities, short sonic transit times and generally smooth borehole walls.

The Umtanum unit lying between 2,615 and 2,780 feet is the thickest single basalt flow within the Grande Roride Formation above the aforementioned cement plug. Figure 10 shows the three-dimensional velocity and caliper logs across this zone. These traces are extracted from the geophysical logs contained in Appendix A. Table I gives the depths to the specific basalt zones shown in Figure 10 which were later hydrologically tested.

As shown in Figure 10, low-density zones are characterized by long acoustic transit times and 1 - to 2 -inch rock breakouts. Two of the zones 


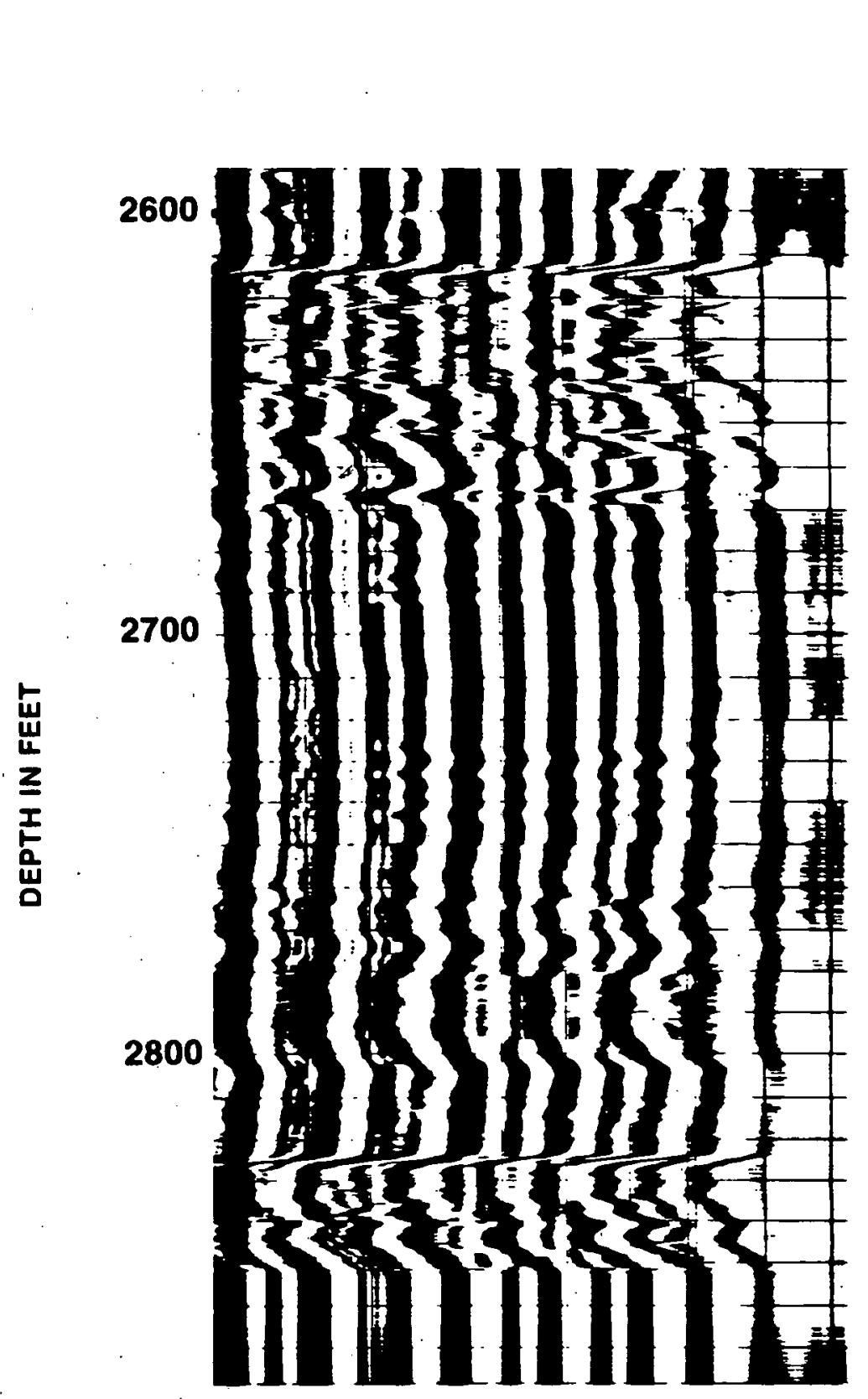

THREE-DIMENSIONAL VELOCITY LOG
AVERAGE

HOLE DIAMETER (INCHES)

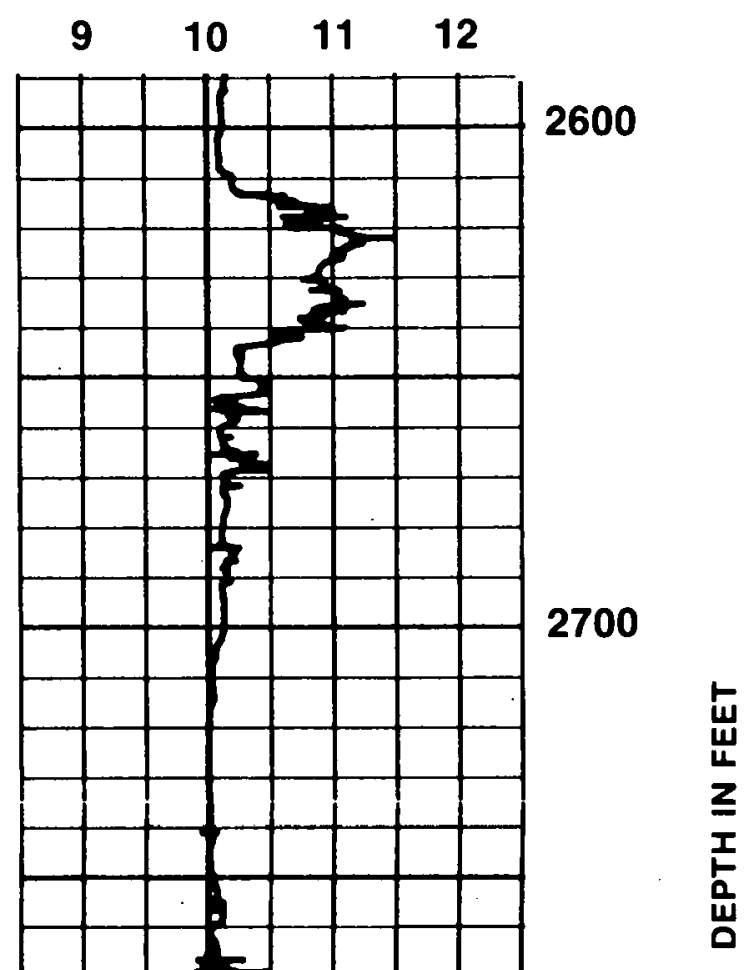

FIGURE 10

GEOPHYSICAL LOG TRACES ACROSS THE INTERVAL

2,600 TO 2,860 FEET BELOW GROUND LEVEL 


\section{TABLE I}

\section{DEPTHS TO SPECIFIC BASALT INTERVALS LATER HYDROLOGICALLY TESTED}

\begin{tabular}{|c|c|}
\hline $\begin{array}{l}\text { DEPTH BELOW } \\
\text { GROUND LEVEL } \\
\text { (FEET) } \\
\end{array}$ & BASALT \\
\hline $2,615-2,665$ & Low* \\
\hline $2,665-2,780$ & 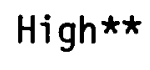 \\
\hline $2,780-2,800$ & Low \\
\hline $2,800-2,825$ & High \\
\hline $2,825-2,850$ & Low \\
\hline P,860-Cement Plug & High \\
\hline
\end{tabular}

*Low-density ( 2.3-2.6 grams per cubic centimeter). **High-density ( 22.7-2.9 grams per cubic centimeter). 
give interesting velocity responses. The vesicularity of the zone between 2,615 and 2,665 feet appears to decrease with depth as the basalt columns are approached. This feature is typically seen in basalt core samples. At 2,640 feet, the acoustic transit time decreases rapidly until denser basalt is reached at 2,665 feet. Less noticeable is the low-density zone lying between 2,780-2,800 feet. Only a slight increase in the acoustic transit time is evident, compared to the above 2 sections; this indicates a zone marked by less vesicularity and higher bulk density. The evenly spaced light and dark strips across the remaining portions of Figure 10 show areas of uniform acoustic transit times. These are characteristic of the dense columnar sections of a basalt flow.

The caliper log in Figure 10 indicates a clean borehole with no apparent mud cake buildup. A comparison between this caliper log and one run 10 years earlier(1) shows no apparent hole degradation.

\section{DRILLSTEM TESTING}

\section{INTRODUCTION}

A drillstem test is an analysis technique for evaluating the pressure response of a rock stratum to fluid injection or withdrawal. The results yield information about the transmissivity, permeability and other properties of the formation. The test begins by lowering a package of "tools" into the borehole at the end of a tubing string. The tools consist of packers, pressure recorders, spacing pipe and mechanical locking devices (Figure 11). The packer is made of expandable rubber which is inflated to seal off and isolate the specific formation zones tested. By opening and closing various tool ports, the formation's fluid pressure is relieved by allowing fluid to flow into the drill pipe. For an injection test, the port openings allow fluid pressure to be applied against the formation. The recorders show the initial pressure buildup and then its decay into the formation. Withdrawal tests result in pressure release from the formation. For additional information covering drillstem testing equipment and procedures, see Reference 24.

During the drillstem test, pressure records are normally obtained from three pressure recorders in the borehole. Each recorder monitors a separate borehole interval. 


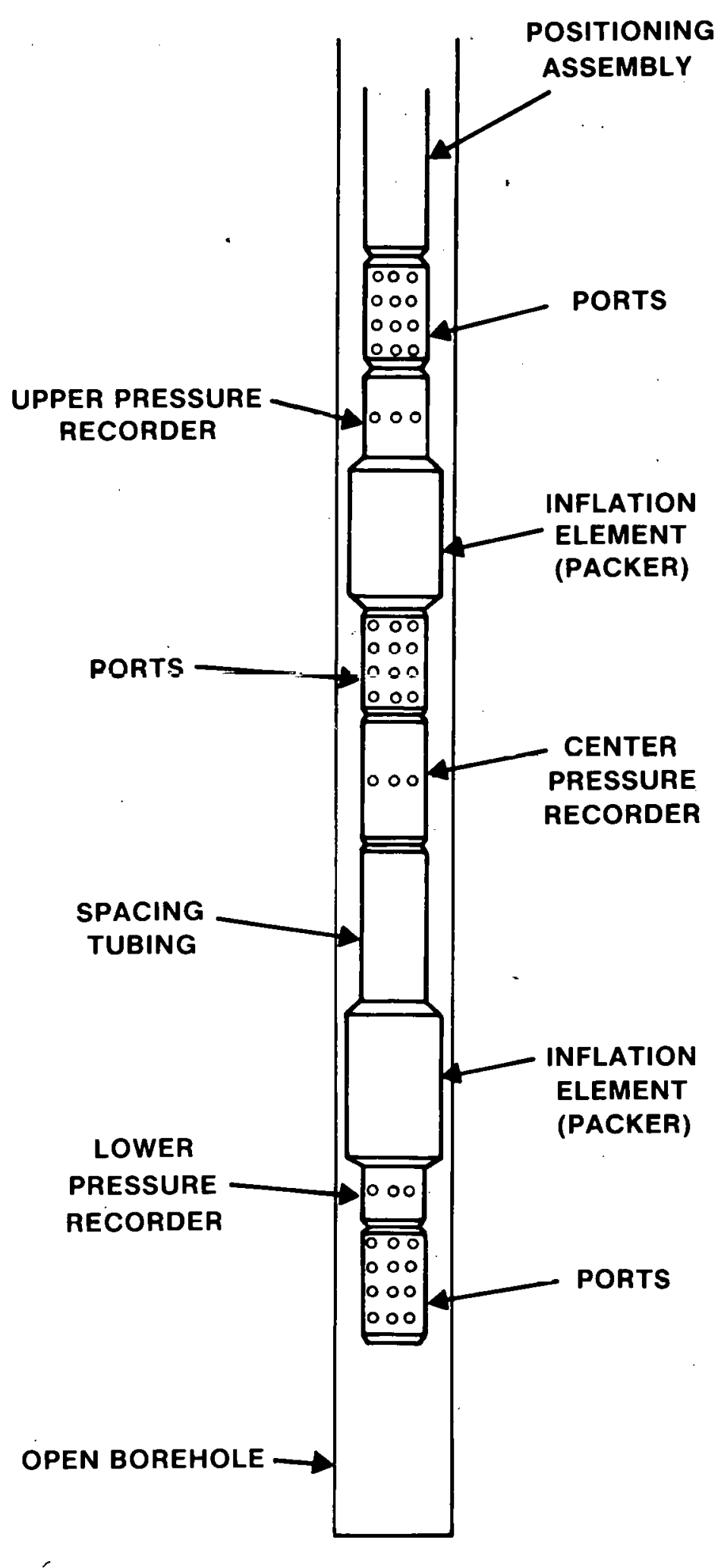

v7812-1.10

\section{FIGURE 11}


Figure 12 shows a typical pressure response recorded for a drillstem test during a single flow period. This response typifies the sequence of operations from tool installation to retrieval. Pressure increases from bottom to top and time increases from left to right. Beginning at point $A$, the pressure increases as the equipment is lowered into the borehole. The vibrations from $A$ to $B$ (and also $F$ to $G$ ) represent movements of the recorder's stylus as the tools are lowered and indicate the stylus is free and responding to pressure changes. The horizontal line at $B$ gives the initial fluid pressure when the packer assembly is positioned opposite the desired rock formation. At $C$, the packers have been set and the test valve opened. Pressure drops as the fluid pressure within the tool equalizes with the formation pressure. Line C-D gives the initial flow period. At $D$, the test valve is closed and the formation pressure is allowed to freely build up to its hydrostatic pressure. Line D-E is the shut-in period for the test. This pressure buildup provides data about the hydrologic properties of the rocks tested. The drill pipe is raised and rotated at $E$, unloading the hydrostatic pressure that had developed across the packed-off formation. The final hydrostatic pressure is read at $F$ and, from $F$ to $G$, the tools are being raised from the borehole.

GENERAL THEORY

The calculation of formation characteristics from drillstem test data is based upon the simplified equations for liquid systems. (25) The following assumptions are made concerning the formations tested and their entrained fluids:

(1) The flow obeys Darcy's law and its pattern is radial in influence;

(2) The reservoir is homogeneous, isotropic, horizontal, uniformly thick and has infinite areal extent;

(3) The production or injection rate is constant; and

(4) The compressibility and absolute viscosity of the entrained fluid are reasonably constant over the working range of pressures and temperatures.

Any variation from these assumptions will cause a deviation from an otherwise straight-line plot of the borehole pressure versus the time 


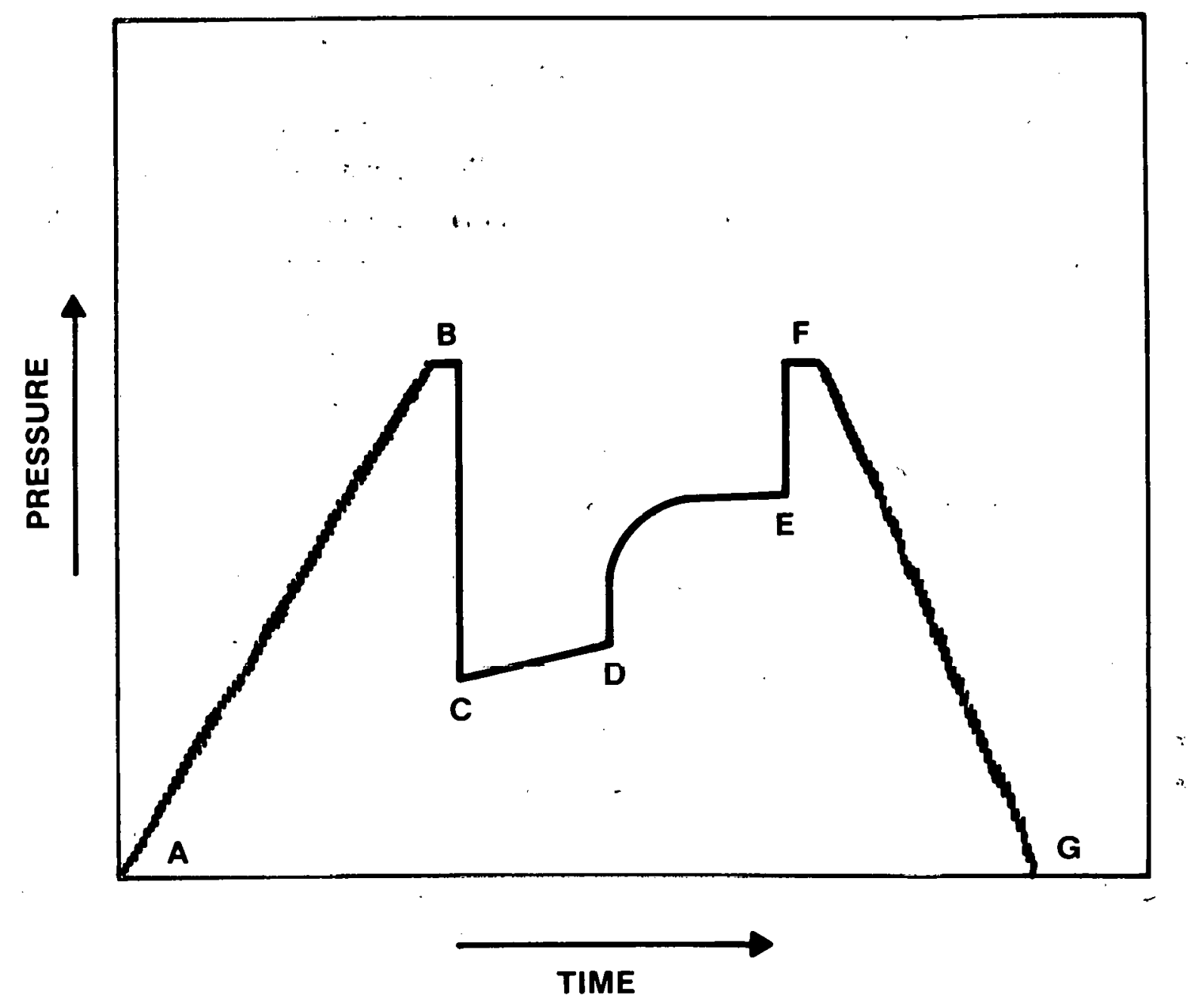

V7812-1.9

FIGURE 12

DRILLSTEM PRESSURE RESPONSE FOR SINGLE FLOW PERIOD 
ratio $(t+\Delta t) \% \Delta t$ as plotted on semi-logarithmic paper ( $t$ equals time of production or injection rate and $\Delta t$ is the shut-in period).

A number of papers have been written discussing the interpretation of pressure buildup and decay curves. These pressure curves are read in time segments $(t)$ and at their corresponding borehole pressures. These data are then plotted on semi-logarithmic paper in pounds per square inch versus the log of $(t+\Delta t) / \Delta t .(26)$ The slope $(m)$ of the buildup. curve is found as the difference of pressure over one $\log$ cycle. Basically, the data interpretation consists of calculating the fluid production rate by computing the number of oil field barrels per day production using the pressure changes that take place during drill pipe fill-up.

The transmissivity (kh) is an index of the effective formation permeability and is calculated from the equation:(25)

$$
\mathrm{kh}=162.6 \frac{\mathrm{Q}}{\mathrm{m}}
$$

where

$k=$ permeability (millidarcy)

$h=$ formation thickness (feet)

$Q=$ production rate (barrels per day)

$m=$ slope across one cycle of pressure buildup curve.

The 162.6 converts oil field units (barrels per day) into units of millidarcy feet. Permeability $(k)$ in millidarcies can then be calculated using $k=k h / h$. Hydraulic conductivity $(K)$ is next determined by the equation:

$$
K=\frac{k \rho g}{\mu}
$$

where

$k=$ permeability (square centimeters)

$\rho=$ density of water (grams per cubic centimeter)

$g=$ acceleration of gravity (centimeters per square second)

$\mu=$ fluid viscosity (grams per centimeter second). 
Other hydrologic properties can be calculated from the pressure buildup curves. Among these is the approximate radius of influence, which is a reasonable indication of the distance from the borehole that the formation was stressed during the test. Generally, the greater the formation's permeability and the lower its effective porosity, the larger will be the radius of influence. This approximation is derived from the permeability and the total time the well has flowed or been shut-in. A flow barrier within this radius will be reflected as a change in slope of the pressure response curve.

Several equations are available for estimating a test's radius of influence $\left(r_{j}\right) \cdot(27-30)$ The equation used in this report is modified after Reference 27 and is:

$$
r_{i}=\sqrt{\frac{4 k t B}{\theta \mu}}
$$

where

$k=$ permeability (square centimeters)

$\mathrm{t}=$ test duration (seconds)

$\theta=$ porosity (dimensionless)

$\mu=$ fluid viscosity ( 1 centipoise)

$B=$ bulk modulus of elasticity for water $\left(6.9 \times 10^{4} \mathrm{gram} /\right.$ centimetersecond square).

The skin factor is also calculated from pressure buildup curves. This factor is an index for examining the pressure effect of a zone of different permeability immediately adjacent to the borehole. This alteration of near-field permeability (the skin) commonly results from pluggage of rock pore space by drilling fluids. Pressure tests conducted across such a zone would show artificially lower or higher permeability values depending upon the permeability of the host rock.

The skin factor has been quantitatively defined as: ${ }^{(31)}$

$$
s=\frac{\Delta P(s k i n)}{Q \mu / 2 \pi k h}
$$


where

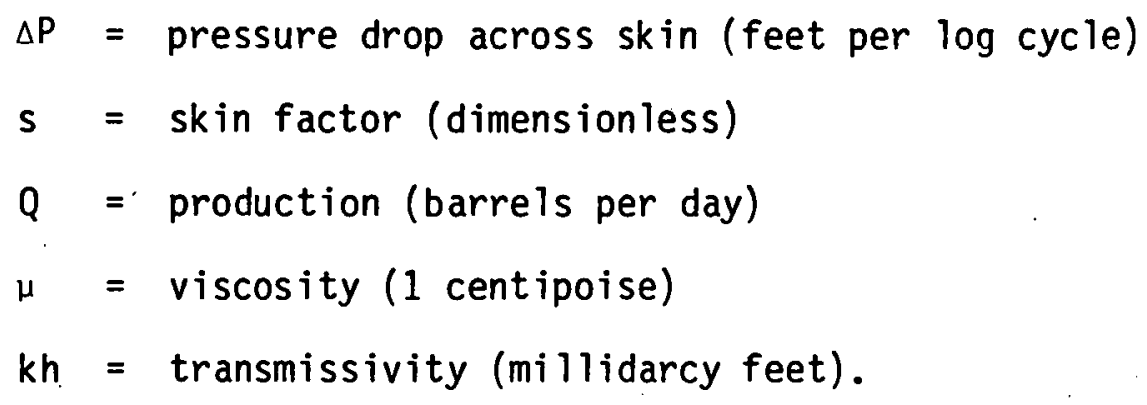

To calculate $s$, it is necessary to measure the well pressure both before and after the test. The radius $\left(r_{s}\right)$, the skin zone around the well and the permeability $\left(k_{s}\right)$ in this zone are related to the skin factor as shown by the following equation: (32)

$$
s=\left(\frac{k}{k_{s}}-1\right) \ln \frac{r_{s}}{r_{w}}
$$

where

$r_{s}=$ radius of skin (feet)

$r_{W}=$ well radius (feet).

If the permeability in the skin zone $\left(k_{s}\right)$ is less than the rest of the rock formation, $s$ will be positive. If the permeabilities are equal $\left(k=k_{s}\right)$, the skin factor is zero. Finally, if the skin permeability is greater than that in the formation, s will be neqative.

Data evaluation begins by visually examining the pressure changes shown on the recorder charts. The charts are examined first to assure the packers have properly sealed and then to verify the pressure changes during testing. Typical pressure chart configurations for successful single-flow period drillstem tests and several common types of failures are found in Reference 33. Pressure charts were carefully inspected after each test to verify proper tool operation and general rock/fluid responses. The pressure variation shown on the recorder charts depends upon the productivity of the formations tested. For the ranges of lowpermeability tested, the recorder charts showed relatively small pressure changes.

\section{WORK DESCRIPTION}

Table II outlines the number and type of drillstem tests performed, 


\section{TABLE II}

LISTING OF ALL DRILLSTEM TESTS CONDUCTED

\begin{tabular}{|c|c|c|c|c|c|}
\hline $\begin{array}{l}\text { TEST } \\
\text { PHASE } \\
\end{array}$ & TEST & DATES(s) & TYPE & DEPTH (FEET) & BASALT DENSITY \\
\hline \multirow[t]{5}{*}{1} & $1-1$ & $4 / 27$. & Production & $2,780-2,820$ & Low* \\
\hline & $1-2$ & $4 / 27-28$ & Production & $2,825-2,860$ & Low \\
\hline & $1-3$ & $4 / 29-5 / 2$ & Production & $2,700-2,770$ & High $\star \star$ \\
\hline & $1-4$ & $5 / 2$ & Production & $2,770-2,860$ & Two low-density zones \\
\hline & $1-5$ & $.5 / 4$ & Production & $2,610-2,690$ & Low \\
\hline & $1-6$ & $5 / 5-5 / 9$ & Injection & $2,740-2,770$ & High \\
\hline & $1-7$ & $5 / 10-5 / 11$ & Production & $1,650-1,780$ & Low \\
\hline & $1-8$ & $5 / 11$ & Production & $1,780-2,860$ & $\begin{array}{l}\text { Numerous low- and } \\
\text { high-density zones }\end{array}$ \\
\hline \multirow[t]{3}{*}{2} & $2-1$ & $9 / 30-10 / 2$ & Injection & $2,780-2,820$ & Low \\
\hline & $2-2$ & $10 / 3-10 / 5$ & Injection & $2,717-2,739$ & High \\
\hline & $2-3$ & $10 / 6-10 / 8$ & Injection & $2,622-2,676$ & Low \\
\hline
\end{tabular}

\footnotetext{
*Low-density ( 2.3-2.6 grams per cubic centimeter). **High-density ( 2.7-2.9 grams per cubic centimeter).
} 
testing schedule and depths, plus the physical character of the basalts tested. Testing was completed in two phases; the first in April and May 1977, and the second between September and October of the same year. Emphasis was placed on determining the hydraulic conductivities for selected low- and high-density basalt zones. Additional information was also acquired on borehole skin effects and the radius of influence of the test. All the original drillstem testing data are given in Appendix $B$. As shown in Table II, eight tests were carried out during Phase 1. of these, four tests $(1-1,1-2,1-3$, and 1-6) produced a measurable pressure response later used for hydrologic analysis. Three of the remaining four tests showed only slight or no pressure change; they were:

Test 1-5 Maximum pressure change over testing time was only 20 pounds per square inch; the rock formation was too tight for adequate interpretation of pressure curve;

Test 1-7 A production test to observe if any pressure responses would occur above and below the interflow separating the Wanapum and Grande Ronde formations; no pressure changes were noted over the test period;

Test 1-8 Production test was to monitor any pressure response occurring above the 1,763-foot depth (mostly Wanapum Formation) resulting from swabbing a 1,070-foot interval of Grande Ronde Formation; no pressure change noted in Wanapum Formation.

The tools did not seat properly during Test 1-4; no usable information was obtainable.

Three injection tests (2-1, 2-2 and 2-3) were conducted during Phase 2; each supplied excellent information. The specific zones were selected from information gained from the Phase 1 testing.

As noted in Table II, both production and injection tests were conducted during the two work phases. For production testing, the borehole was stressed by pumping or swabbing out water, and the downhole pressure changes were monitored as hydrostatic conditions returned. Injection testing was performed by subjecting the formation to pressures greater than hydrostatic. This was accomplished by injecting water through the drill pipe and into the portion of the formation isolated by packers. The fluid pressure response of the rock was monitored as it returned to hydrostatic conditions.

All tests conducted in RSH-1 were run for times ranging from a few hours to .48 hours. The longer intervals furnished more data points 
on which to base interpretations. Even over the longer periods, some tests did not reach static conditions making it necessary to extrapolate fluid pressures back to the static levels.

An electric water level indicator was used during several tests to provide additional assurance that the downhole pressure recorders were giving reliable data. This water level indicator was used to monitor the declining fluid level in the drill pipe. The data comparisons were close between these measurements and those from the pressure recorders. The electric tape measurements are contained in Appendix B immediately following the pressure recorder data. These two sources of information provided for a narrow spread of calculated permeability values.

\section{INTERPRETATION}

\section{Hydraulic Conductivity}

Calculations of hydraulic conductivity and skin factor are listed in Table III for seven drillstem tests completed within the Grande Ronde Formation. The downhole position of each test is shown in Figure 13 opposite a three-dimensional velocity log trace. Four tests were conducted across vesicular and rubbly low-density zones (Tests 1-1, 1-2, 2-1 and 2-3), while the remaining three straddled sections of denser columnar basalt. Two tests (1-1 and 2-1) were completed across the same rock interval, but the first was a production test and the second an injection test. Packer spacing for all tests varied between 22 and 70 feet.

The techniques used to calculate hydraulic conductivity and the skin factor were discussed earlier. An excellent review of these techniques is detailed in Reference 26.

Hydraulic conductivities of the low- and high-density zones differed by only 2 orders of magnitude, although, as will be noted below, some of this variation may result from using two different testing techniques. Values across the low-density zones ranged from $1.7 \times 10^{-7}$ to $3.8 \times$ $10^{-9}$ centimeters per second and those for the denser columnar basalts between $1.1 \times 10^{-8}$ and $4.7 \times 10^{-9}$ centimeters per second. Except for Test 1-1, there was no discernible difference between the hydraulic conductivities of the low- and high-density zones. This similarity appears to indicate that the individual vesicles and fractures within the low-density zones are not interconnected. When stressed, the basalt 
VALUES OF HYDRAULIC CONDUCTIVITY AND SKIN FACTOR

\begin{tabular}{|c|c|c|c|c|c|c|}
\hline $\begin{array}{l}\text { TEST } \\
\text { PHASE } \\
\end{array}$ & $\begin{array}{c}\text { TEST } \\
\text { NUMBER } \\
\end{array}$ & TEST TYPE & $\begin{array}{l}\text { TEST INTERVAL } \\
\text { (FEET) } \\
\end{array}$ & $\begin{array}{l}\text { BASALT } \\
\text { DENSITY } \\
\end{array}$ & $\begin{array}{l}\text { HYDRAULIC CONDUCTIVITY } \\
\text { (CENTIMETERS PER SECOND) }\end{array}$ & $\begin{array}{l}\text { SKIN } \\
\text { FACTOR } \\
\end{array}$ \\
\hline \multirow[t]{4}{*}{1} & $1-1$ & Production & $2,780-2,820$ & Low* & $1.7 \times 10^{-7 \star \star \star}$ & -4 \\
\hline & $1-2$ & Production & $2,825-2,860$ & Low & $3.0 \times 10^{-8}-3.5 \times 10^{-8}$ & -4 \\
\hline & $1-3$ & Prcduction & $2,700-2,770$ & High $\star \star$ & $4.7 \times 10^{-9}-6.1 \times 10^{-9}$ & -3 \\
\hline & $1-6$ & Injection & $2,740-2,770$ & High & $1.1 \times 10^{-8}-1.4 \times 10^{-8}$ & -1 \\
\hline \multirow[t]{3}{*}{2} & $2-1$ & Injection & $\varepsilon, 780-2,820$ & Low & $7.7 \times 10^{-9}-8.9 \times 10^{-9}$ & -2 \\
\hline & $2-2$ & Injection & $2,717-2,739$ & High & $1.5 \times 10^{-8 \star \star \star}$ & -3 \\
\hline & $2-3$ & Injection & $2,622-2,676$ & Low & $3.8 \times 10^{-9}-5.8 \times 10^{-9}$ & -2 \\
\hline
\end{tabular}

*Low-density ( 2.3-i்.6 grans per cubic centimeter). **High-density ( 2.7-2.9 gräms per cubic centimeter).

$\star \star \star$ Identical values were calculated using recorder and electric water level incicator measurements. 
TEST NUMBER

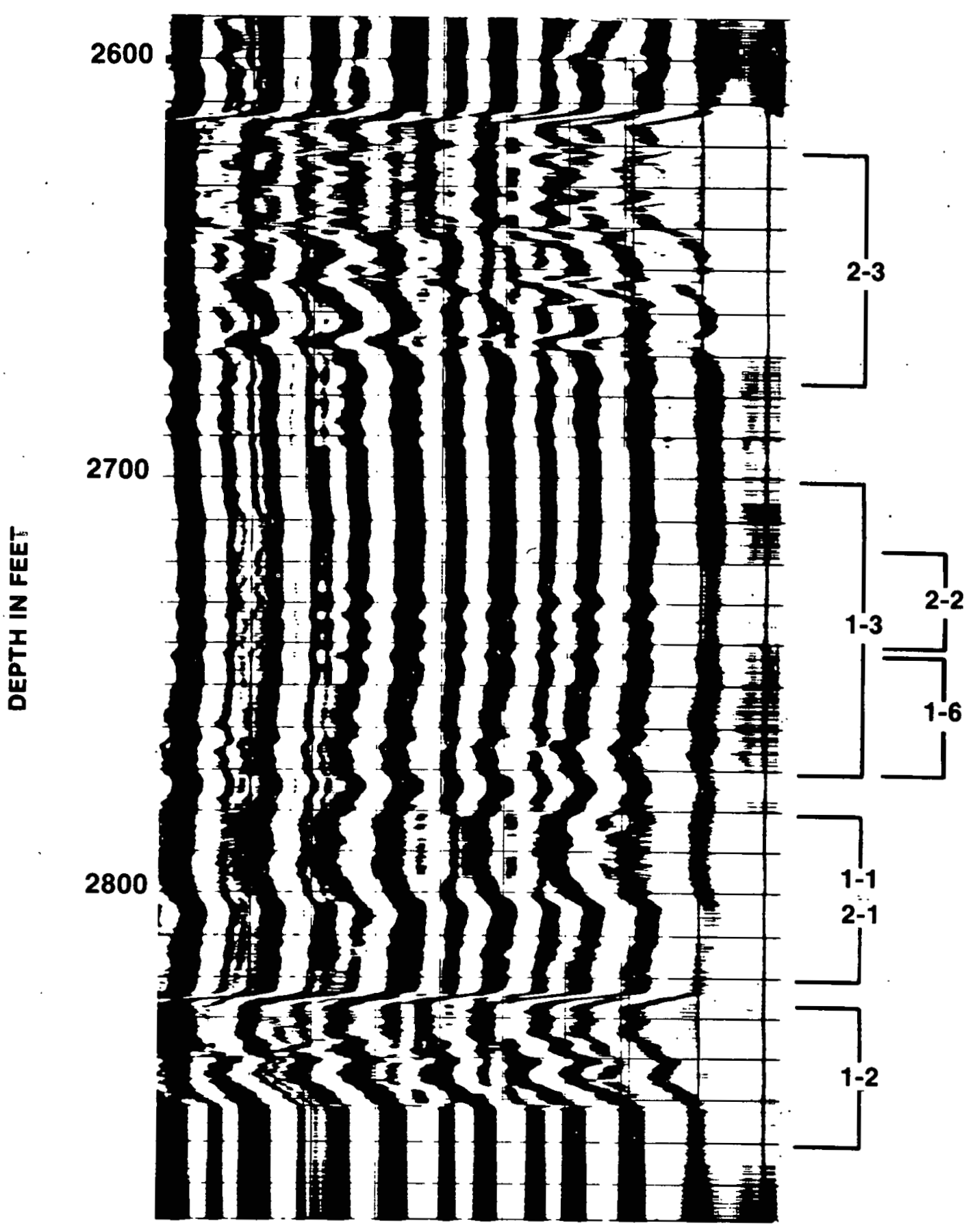

FIGURE 13

DOWNHOLE POSITION OF SEVEN DRILLSTEM TESTS 
responded as a tight rock mass similar to the response of a zone of high-density columnar basalt.

Tests 1-1 and 2-1 were conducted across the same downhole interval; the only difference between the two being the first was a production test and the second an injection test. The calculated hydraulic conductivities differ by over one order of magnitude. This same range of difference is observed in comparing the results of production tests $(1-3$ to 2-2 and 1-6). This spread of data appears inherent when comparing results using the two testing methods.

Five drillstem tests were earlier performed ${ }^{(1)}$ across selected low-density zones within the Columbia River Basalt Group. The reported hydraulic conductivities were $1.7 \times 10^{-5}, 7.7 \times 10^{-6}, 1.9 \times 10^{-7}$ (two tests) and $9.7 \times 10^{-8}$ centimeters per second. The highest of these values was qualified as a poor test. (1) The $9.7 \times 10^{-8}$ centimeters per second value was calculated for the basalt section straddled between the depths of 2,614 to 2,690 feet. This crossed the same interval evaluated in Test 2-3 (Table III). Both values agree within one order of magnitude and indicate a very tight rock mass.

\section{Skin Factor}

The negative values reported in Table III reveal that the basalts immediately adjacent to the borehole are slightly more permeable than the overall rock stratum. Because of the negative skin, less of a pressure drop $(\Delta P)$ is obtained across the test zone proportional to the rate of fluid production or injection (Q). In tests where the radius of influence is small, a large negative skin $(\geq 7)$ reveals that the permeability measured is probably greater than the undisturbed rock permeability. However, the skin values reported in Table III show:

(1) There was no interfering mud cake across the test horizons which would have produced a positive skin; and

(2) The reported hydraulic conductivity values are probably characteristic and conservative for the rocks tested.

\section{Static Water Pressures}

Except for a single cement plug, RSH-1 has been hydraulically open to ground water cross-flow since its completion in 1958. During this time, average or composite water pressures have been establishing themselves in the well. Those interflows contributing water (of higher pressure) would 
presently show lower pressures than originally found before drilling. The opposite would be true for the interflows accepting ground water from zones of higher potential. For this reason, it was not possible to obtain meaningful static water pressures during the short-term drillstem tests.

\section{Radius of Inf luence}

The equation ${ }^{(28)}$ used to interpret the radius of influence for the seven drillstem tests given in Table III is explained in the section entitled "General Theory;" results are listed in Table IV. In each instance, the radius of influence was calculated as less than one centimeter from the borehole. It is the authors' opinion that these values are minimum estimates and that the actual radius of influence probably extends on the order of 100 centimeters from the borehole. Because of the variability in rock properties over short distances, these results should be considered as only an order of magnitude estimate. Generally, the smaller the radius of influence, the lower will be the permeability and effective porosity of the rock. The small values given in Table IV indicate that the basalts were hydraulically tight permitting only limited rock volumes to be stressed. It can then be assumed the test results are characteristic of the basalt rock within the immediate vicinity of the borehole.

\section{CONCLUSIONS}

Several conclusions can be drawn from the geophysical logging and hydrologic testing of Well RSH-1.

(1) In comparison with the Wanapum Formation, the Grande Ronde Formation contains a greater percentage of thick high-density basalt zones. Ninety-two percent of the denser basalts with in the Wanapum are less than 50 feet thick, compared to 55 percent in the Grande Ronde.

(2) Low-density zone thicknesses are not dependent upon the thicknesses of the underlying denser basalts. This suggests that the thickness of a basalt interflow bears no direct relation to the thickness of the associated columnar basalt.

(3) Calculations of hydraulic conductivity for both low- and high-density basalts give very small values. Values in the lower density zones ranged between $1.7 \times 10^{-7}$ and $3.8 \times 10^{-9}$ centimeters per second. Values for the denser basalts were between $1.1 \times 10^{-8}$ and $4.7 \times 10^{-9}$ centimeters per second. 
TABLE IV

VALUES FOR RADIUS OF INFLUENCE

\begin{tabular}{|c|c|c|c|c|}
\hline $\begin{array}{l}\text { TEST } \\
\text { PHASE } \\
\end{array}$ & $\begin{array}{c}\text { TEST } \\
\text { NUMBER } \\
\end{array}$ & $\begin{array}{c}\text { PERMEABLITY } \\
\text { (SQUARE } \\
\text { CENTIMETERS)* } \\
\end{array}$ & $\begin{array}{c}\text { TIME } \\
\text { (SECONDS) } \\
\end{array}$ & $\begin{array}{c}\text { RADIUS OF } \\
\text { INFLUENCE } \\
\text { (CENTIMETERS)** }\end{array}$ \\
\hline \multirow[t]{4}{*}{1} & $1-1$ & $1.7 \times 10^{-12}$ & $8.4 \times 10^{3}$ & 0.6 \\
\hline & $1-2$ & $3.3 \times 10^{-13}$ & $5.46 \times 10^{4}$ & 0.7 \\
\hline & $1-3$ & $5.5 \times 10^{-14}$ & $1.86 \times 10^{5}$ & 0.5 \\
\hline & $1-6$ & $1.3 \times 10-1.3$ & $1.41 \times 10^{5}$ & 0.7 \\
\hline \multirow[t]{3}{*}{2} & $2-1$ & $8.5 \times 10-14$ & $1.30 \times 10^{5}$ & 0.6 \\
\hline & $?-?$ & $1.5 \times 10-13$ & $1.48 \times 1,0^{5}$ & 0.8 \\
\hline & $2-3$ & $4.9 \times 10-14$ & $1.48 \times 10^{5}$ & 0.4 \\
\hline
\end{tabular}

*Average permeability from Table III:

$\star \star 1$ percent porosity assumed. 
(4) Skin factors revealed the drillstem tests were conducted across clean rock zones having no detectable mud cake buildup.

(5) The radius of influence for each drillstem test was at a maximum of a few feet from the borehole.

(6) Because of low quantities of water found in the basalt, injection testing proved more reliable than production testing.

\section{ACKNOWLEDGMENTS}

The authors acknowledge the cooperation of Drs. L. S. Leonhart and C. W. Myers and Messrs. R. L. Biggerstaff and D. J. Brown who reviewed this report. Appreciation goes to Mr. S. C. Anama of Lynes Inc., who conducted the drillstem tests with the report's co-author, Mr. P. A. Eddy. Special recognition is given to $\mathrm{Mr}$. Eddy for his permeability calculations contained in this report.

\section{REFERENCES}

1. J. R. Raymond and D. D. Tillson, Evaluation of a Thick Basalt Sequence in South-Central Washington, BNWL-776, Battelle, Pacific Northwest Laboratories, Richland, Washington (1968).

2. A. C. Waters, "Volcanic Rocks and the Tectonic Cycle," Geological Society of America Special Paper 62, 703-722 (1955).

3. J. Gray and L. R. Kittleman, "Geochronometry of the Columbia River Basalt and Associated Floras of Eastern Washington and Western Idaho," American Journal of Science, 265 (4), 257-291 (1967).

4. J. F. Evernden and G. T. James, "Potassium Argon Dates and the Tertiary Floras of North America," American Journal of Science, 262 (8), 945-974 (1964).

5. D. A. Holmgren, "K/Ar Dates and Paleomagnetics of the Type Yakima Basalt, Central Washington," in Proceedings of the Second Columbia River Basalt Symposium, Cheney, Washington, March 1969, Eastern Washington State College Press, Cheney, Washington (1970).

6. N. D. Watkins, "Paleomagnetism of the Columbia Plateau," Journal of Geophysical Research, 70 (6), 1379-1406 (1965).

7. D. A. Swanson and T. L. Wright, "Bedrock Geology of the Northern Columbia Plateau and Adjacent Areas," in The Channeled Scabland, V. R. Baker and D. Nummendal, editors, National Aeronautics and Space Administration, Washington, D. C. (June 1978). 
8. C. W. Myers, Yakima Basalt Flows Near Vantage and from Core Holes in the Pasco Basin, Washington, Ph. D. Dissertation, University of California at Santa Cruz, Santa Cruz, California (1973).

9. C. W. Myers and D. J. Brown, "Stratigraphy of the Yakima Basalt in the Pasco Basin, Washington," Geological Society of America (Cordilleran Section), $\underline{5}$ (1), 80 (1973).

10. D. J. Brown and R. K. Ledgerwood, "Stratigraphy and Structure of Yakima Basalt in Pasco Basin, Washington," Geologic Field Trips in Northern Oregon and Southern Washington, Oregon Department of GeoTogy and Minera I Industries Bulletin, 77, 171-181 (1973).

11. K. R. Newman, "Palynology of Interflow Sediments from the Standard Oil Company of California Rattlesnake Hills No. 1 Well, Benton County, Washington," in Proceedings of the Second Columbia River Basalt Symposium, Cheney, Washington, March 1969, Eastern Washington State College Press, Cheney, Washington (1970).

12. D. P. Hi 11, "Crustal and Upper Mantle Structure of the Columbia River Plateau from Long Range Seismic Refraction Measurements, "Geological Society of America Bulletin 83, 1639-1648 (1972).

13. J. H. Skehan, A Continental-Oceanic Crustal Boundary in the Pacific Northwest, AFCRL-65-904, Air Force Cambridge Research Laboratories, Office of Aerospace Research, Bedford, Massachusetts (1965).

14. E. Raisz, "The 01 ympic-Wall lowa Lineament," American Journal of Science, 243-A, 479 (1945).

15. T. Cantwe 11, P. Nelson, J. Webb, and A. S. Orange, "Deep Resistivity Measurements in the Pacific Northwest," Journal of Geophysical Research, 70 (8), 1931-1937 (1965).

16. S. L. Robbins, R. J. Burt, and D. 0. Gregg, "Gravity and Aeromagnetic Study of Part of the Yakima River Basin, Washington," U. S. Geological Survey Professional Paper 726-E (1975).

17. D. E. Peterson and R. E. Brown, Gravity Anomalies and Geologic Structures of the Central Part of the Columbia River Basalt Plateau, BNWL-SA-812, Battelle, Pacific Northwest Laboratories, Richland, Washington (1966).

18. W. H. Taubeneck, "An Evaluation of Tectonic Rotation in the Pacific Northwest," Journal of Geophysical Research, 71 (8), 2113-2120 (1966), and 72, 1415-1421 (1967).

19. A. C. Waters, "Basalt Magma Types and Their Tectonic Association: Pacific Northwest of the United States, "American Geophysical Union Geophysical Monographs, $\underline{6}, 158-170$ (1962).

20. A. B. Griggs, "The Columbia River Basalt Group in the Spokane Quadrangle, Washington, Idaho, and Montana," U. S. Geological Survey Bulletin, 1413, 39 (1976). 
21. R. A. Deju, P. A. Eddy, M. W. Grutzeck, and C. W. Myers, Environmental Factors Needed to Establish the Geotechnical Feasibility of Storing Radioactive Waste in Columbia River Basalt, RHO-ST-8, RockwelT Hanford Operations, RichTand, Washington (September 1977).

22. Exploration Data Consultants, Inc., Fenix and Scisson, Inc., Borehole Gravity Meter Survey Report, June 15-17, 1978, October 17-19, 1978, Lakewood, Colorado

23. H. Guyod and L. E. Shane, Geophysical Well Logging, Hubert Guyod and Company, Houston, Texas (1969).

24. H. K. Van Poolen, "Status of Drill-Stem Testing Techniques and Analysis," Journal of Petroleum Technology, 333-339 (1961).

25. D. R. Horner, "Pressure Buildup in Wells," in Proceedings of the Third World Petroleum Congress, E. J. Brill, Editor, Leiden Publishing, II, 503 (1951).

26. C. S. Matthews and D. G. Russe11, "Pressure Buildup and Flow Test in Wells", Monograph Volume 1 of Society of Petroleum Engineers, Storm Printing Corporation, Dallas, Texas (1967).

27. J. H. Moran, and E. E. Finklea, "Analys is of Pressure Build-up Data. Obtained by the Wire Line Formation Tester, "Paper SPE 177; in Proceedings of the 36 th Annual Fall Meeting Society of Petroleum Engineers, Dallas, Texas, (October 1961).

28. P. J. Jones, "Draw Down Exploration, Reservoir Limit, Well and Formation Evaluation, "Permian Basin 0il Recovery Conference of American Institute of Mining Engineers, Midland, Texas (ApriT 1957).

29. W. Hurst, 0. K. Hanie, and R. N. Walker, "Some Problems in Pressure Build-up," Paper SPE 145, in Proceedings of the 36th Annual Fall Meeting, Society of Petroleum Engineers, Dallas, Texas (October 1961), also "New Concept Extends Pressure Build-up Analysis," Petroleum Engineering, 34 (9), 41 (August 1962).

30. L. F. Maier, "Recent Developments in the Interpretation and Application of DST Data," Journal of Petroleum Technology, XIV (11), (November 1962).

31. A. F. Everdingen, "The Skin Effect and Its Influence on the Productive Capacity of a Well," Transactions of the American Institute of Mining Engineers, 198, 171-176 (1953).

32. M. F. Hawkins Jr., "A Note on the Skin Factor," Transactions of the American Institute of Mining Engineers, 207, 356-357 (1956).

33. W. Marshall Black, "A Review of Drill-Stem Testing Techniques and Analysis," Journal of Petroleum Technology, 21-30 (June 1956). 


\title{
DISTRIBUTION
}

\author{
Number of \\ Copies \\ 1 \\ J. F. T. AGAPITO \\ 1 \\ AMOCO \\ G. Servos \\ 1 \\ H. G. ANDERSON \\ 1 \\ ATOMICS INTERNATIONAL \\ H. C. Weiseneck \\ 4 \\ BATTELLE-OFFICE OF NUCLEAR WASTE ISOLATION \\ J. M. Batch \\ R. E. Heineman \\ M. Kahnemuyi \\ P. F. Patchick \\ BOEING COMPUTER SERVICES RICHLAND, INC. \\ R. W. Nelson \\ 1 \\ BROOK.HAVEN NATIONAL LABORATORY \\ P. W. Levy \\ 1 \\ BROWN UNIVERSITY \\ B. Giletti \\ 1 \\ CALIFORNIA ENERGY RESOURCES CONSERVATION \\ AND DEVELOPMENT COMMISSION \\ W. Irving \\ 2 \\ CENTRAL WASHINGTON UNIVERSITY \\ Department of Geology \\ Library \\ 1 COLORADO SCHOOL OF MINES \\ F. D. Wang \\ 1 DARTMOUTH COLLEGE \\ J. Lyons
}


Distribution (continued)

Number of

Copies

2

EASTERN WASHINGTON UNIVERSITY

Department of Geology

Library

1

FOUNDATION SCIENCES, INC.

D. J. Dodds

1 THE GEOLOGICAL SOCIETY OF AMERICA, INC.

J. C. Frye

1 GEOSCIENCE RESEARCH CONSULTANTS

J. G. Bond

1

HARVARD UNIVERSITY

R. Siever

2

IDAHO BUREAU OF MINES AND GEOLOGY

M. M. Miller

Library

1

KANSAS STATE GEOLOGICAL SURVEY

W. W. Hambleton

2

LAWRENCE BERKELEY LABORATORY

L. V. Benson

P. A. Witherspoon

1

LAWRENCE LIVERMORE LABORATORIES

L. Ramspott

1

LOS ALAMOS SCIENTIFIC LABORATORY

M. L. Wheeler

1 LYNES, INC.

S. C. Anama

1 OREGON STATE DEPARTMENT OF GEOLOGY AND MINERAL INDUSTRIES

J. D. Beaulieu 


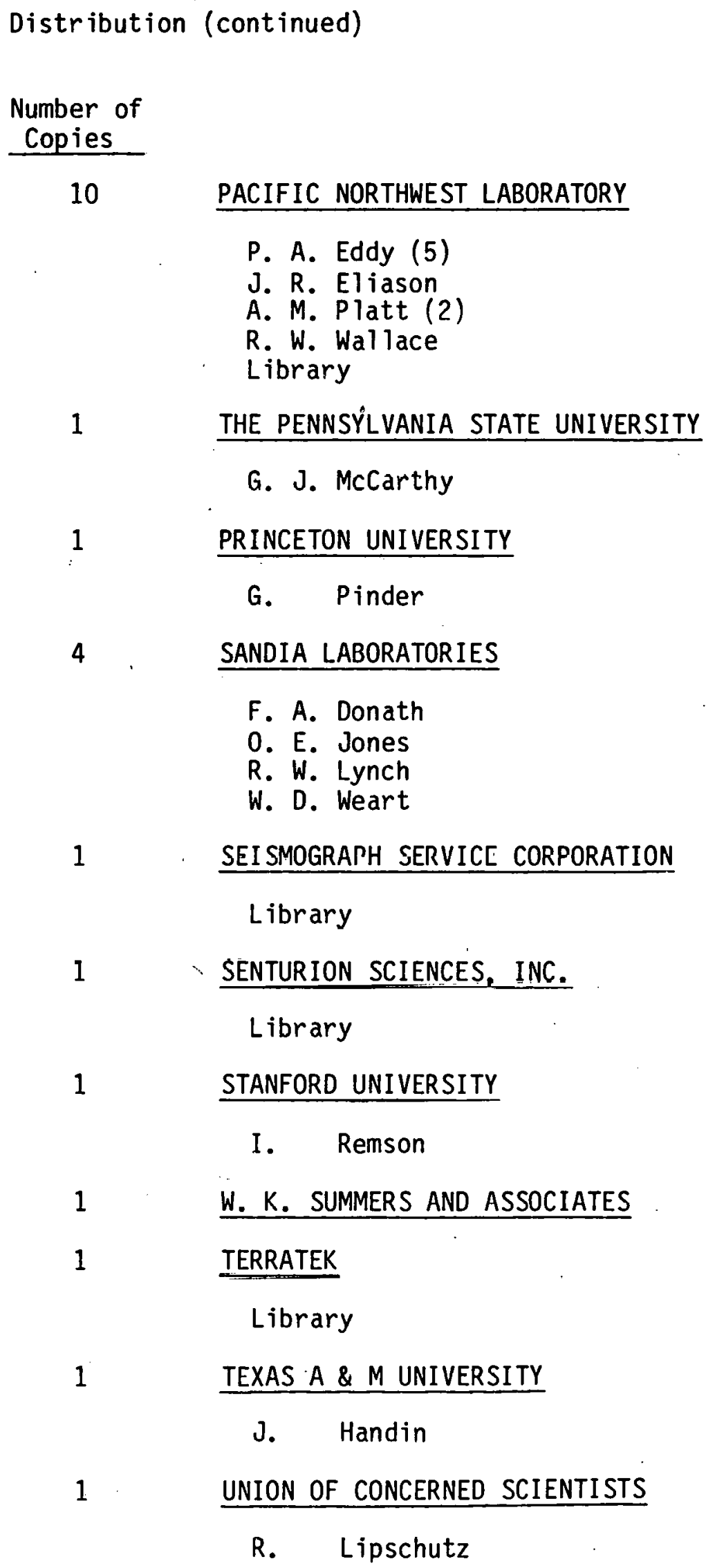

1 SEISMOGRAPH SERVICE CORPORATION

Library

1 SENTURION SCIENCES, INC.

Library

1 STANFORD UNIVERSITY

I. Remson

1 W. K. SUMMERS AND ASSOCIATES

1 TERRATEK

Library

1 TEXAS A \& M UNIVERSITY

J. Handin

1 UNION OF CONCERNED SCIENTISTS

R. Lipschutz 


\section{Distribution (continued)}

\section{Number of \\ Copies}

1

?

1

1

1

10

2

1

15
UNITED NUCLEAR INDUSTRIES, INC.

G. 0. Amy

U. S. ARMY CORPS OF ENGINEERS

Wall la Walla District Geologist

Walla Walla District Librarian

U. S. BUREAU OF MINES

J. W. Corwine

U. S. BUREAU OF RECLAMATION

D. Newmann

U. S. DEPARTMENT OF ENERGY-ALBUQUERQUE OPERATIONS OFFICE

D. T. Schue ler

U. S. DEPARTMENT OF ENERGY-COLUMBUS PROGRAM OFFICE

J. Neff

U. S. DEPARTMENT OF ENERGY-HEADQUARTERS

R. H. Campbell

D. B. LeClaire

C. R. Cooley

M. W. Frei

C. H. George

C. A. Heath

S. Meyers

R. G. Romatowski

R. Stein

D. L. Vieth

U. S. DEPARTMENT OF ENERGY-NEVADA OPERATIONS OFFICE

D. G. Jackson

R. M. Nélson

U. S. DEPARTMENT OF ENERGY-OAK RIDGE OPERATIONS OFFICE

C. A. Keller

U. S. DEPARTMENT OF ENERGY-RICHLAND OPERATIONS OFFICE
J. W. Anttonen
P. G. Harris
T. A. Bauman
A. G. Lassila
J. C. Cummings
J. A. Fernandez
R. B. Goranson (2)
D. J. Squires (4)
F. R. Standerfer
M. W. Tiernan
P. S. Van Loan 
Distribution (continued)

Number of Copies

U. S. DEPARTMENT OF ENERGY-SAN FRANCISCO OPERATIONS OFFICE

J. S. Muhlestein

U. S. DEPARTMENT OF ENERGY-TECHNICAL INFORMATION CENTER

3

U. S. ENVIRONMENTAL PROTECTION AGENCY
R. Kaufman
G. L. Meyers
J. Sceva

6

U. S. GEOLOGICAL SURVEY
C. Collier.
G. D. DeBuchananne
R. Schneider
$P$. R. Stevens
D. A. Swanson
W. S. Twenhofel

3

U. S. NUCLEAR REGULATORY COMMISSION

J. 0. Bunting, Jr.

J. C. Malaro

E. P. Regnier

2

UNIVERSITY OF IDAHO

Department of Geology Library

2

UNIVERSITY OF MINNESOTA

C. A. Fairhurst

C. M. St. John

2

UNIVERSITY OF OREGON

G. Goles

Library

2

UNIVERSITY OF WASHINGTON

Department of Geology Library

1 VANDERBILT UNIVERSITY

F. L. Parker 
Distribution (continued)

Number of

Copies

WASHINGTON PUBLIC POWER SUPPLY SYSTEM, INC.

D. D. Tillson

2

WASHINGTON STATE DEPARTMENT OF ECOLOGY

P. M. Grimstad

Library

2

WASHINGTON STATE DEPARTMENT OF NATURAL RESOURCES

V. E. Livingston

Library

1

WASHINGTON STATE ENERGY FACILITY SITE EVALUATION COUNCIL

N. D. Lewis

2

WASHINGTON STATE UNIVERSITY

Department of Geology

Library

1 A. C. WATERS

1

WESTINGHOUSE ADVANCED ENERGY SYSTEMS

T. Hak 1

1

WESTINGHOUSE HANFORD COMPANY

A. G. Blasewitz

1

WOODWARD-CLYDE CONSULTANTS

Library

97

ROCKWELL HANFORD OPERATIONS
H. Babad
J. E. Kinzer
D. J. Cockeram
E. J. Kosiancic
R. A. Deju
P. J. Fritch
J. H. Roecker
R. E. Gephart (5)
R. J. Gimera
L. Wi The Imi
R. D. Hammond
Basalt Waste Isolation Program Library (75)
Document Control (4)
W. F. Heine
Records Retention Centers (2) 
APPENDIX A

GEOPHYSICAL LOG TRACES 


\begin{tabular}{|l|l|l|l|l|}
\hline \multicolumn{1}{|l|}{} & \\
\hline & & \\
\hline
\end{tabular}

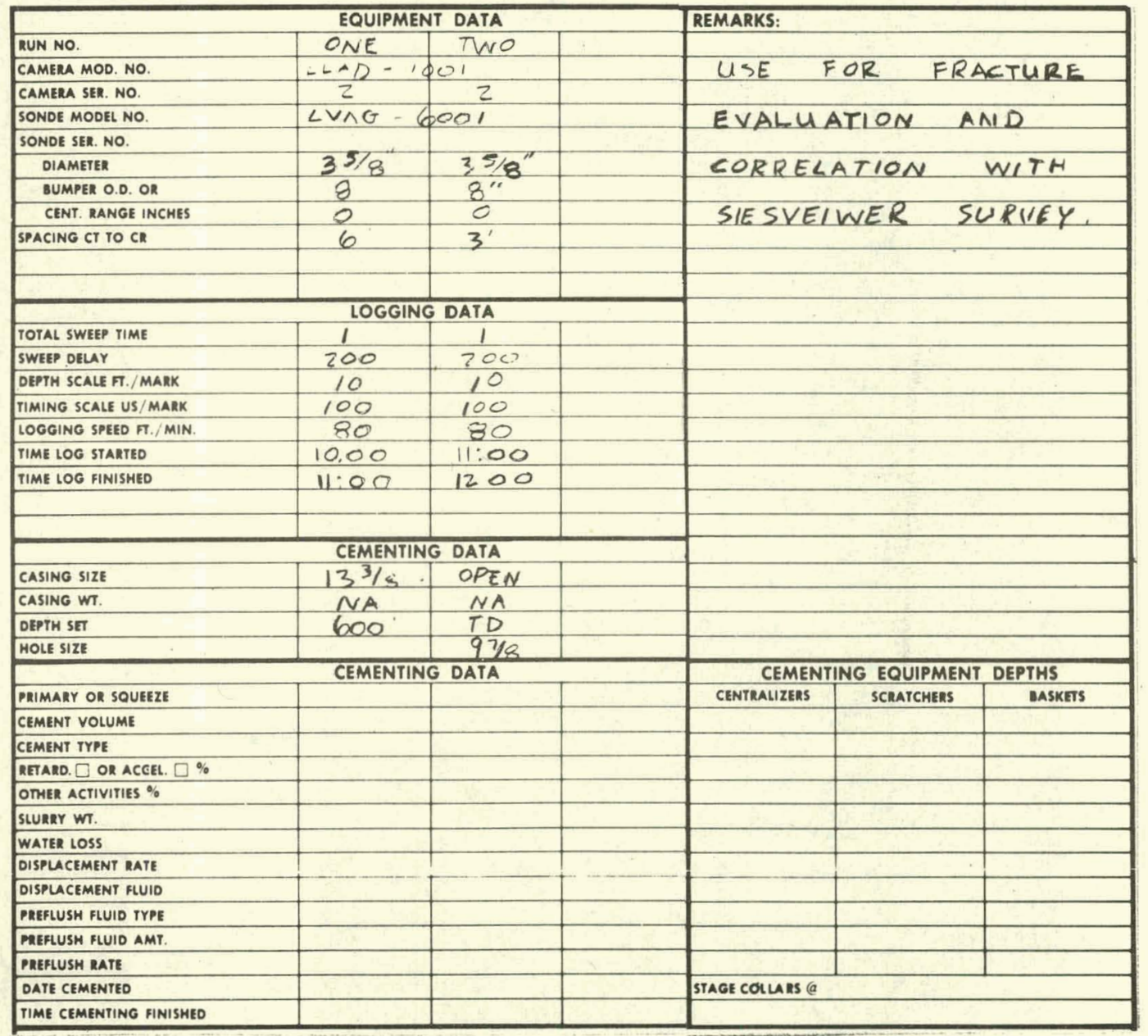

all depths in feet below ground level 

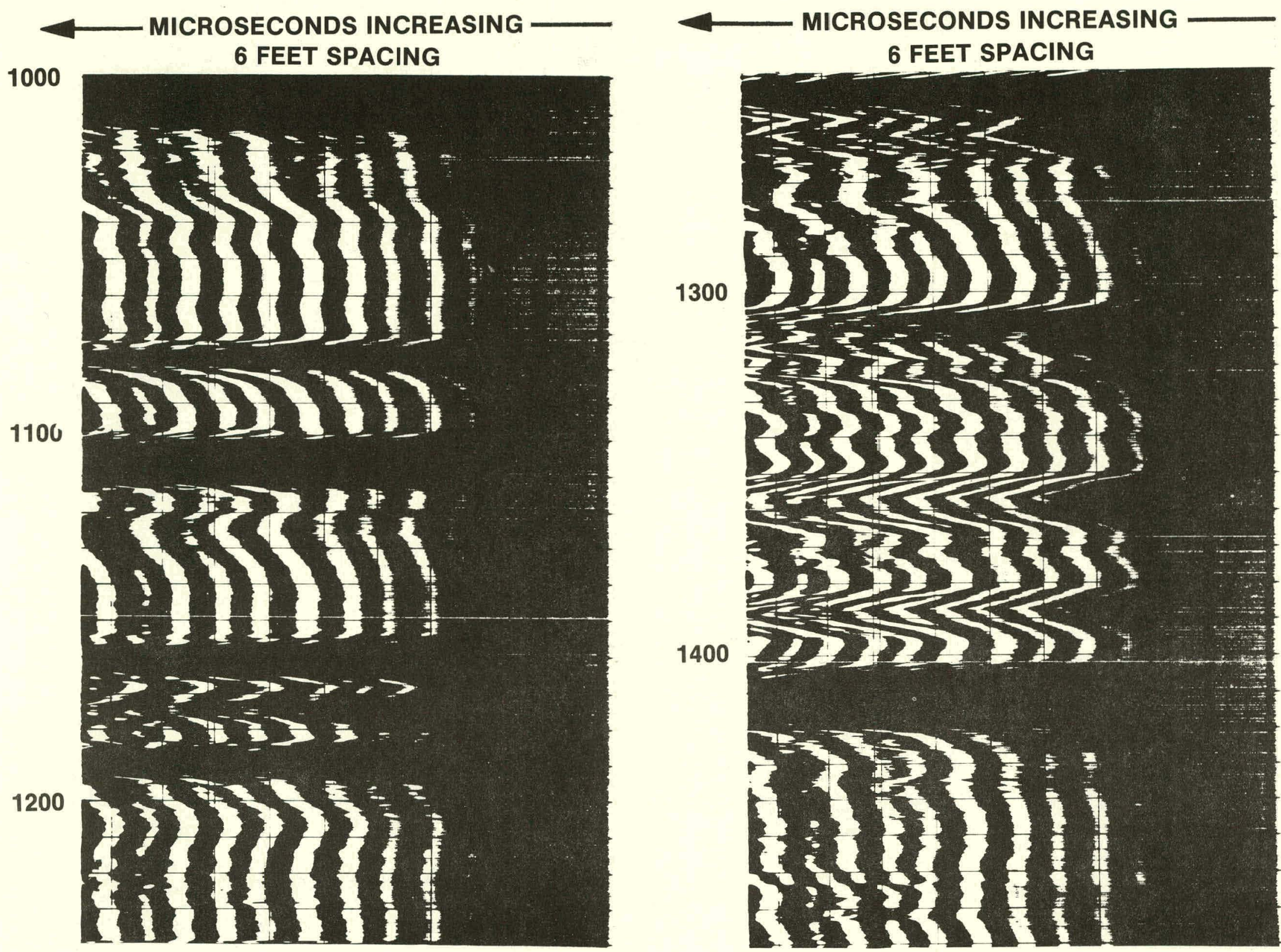

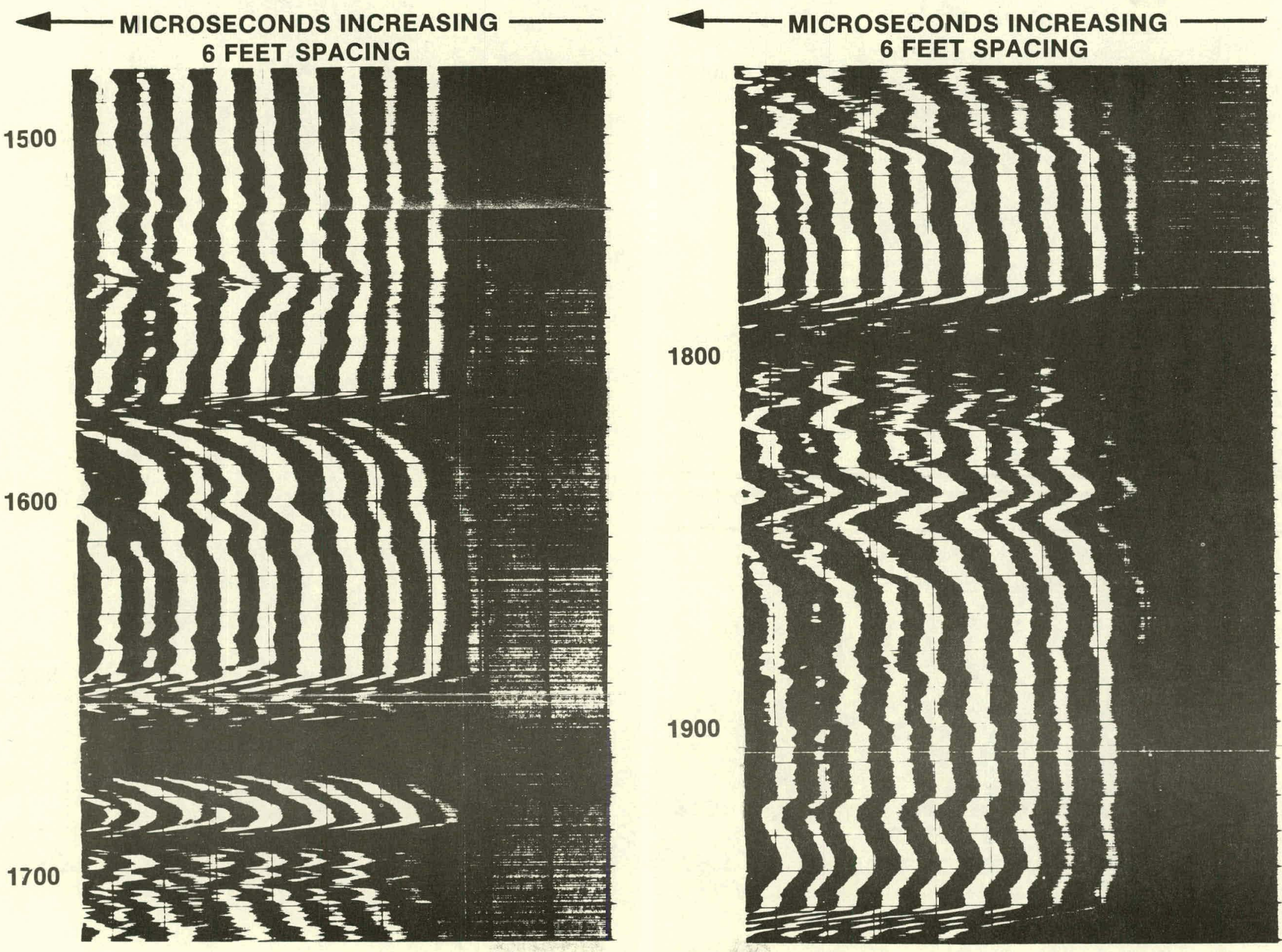

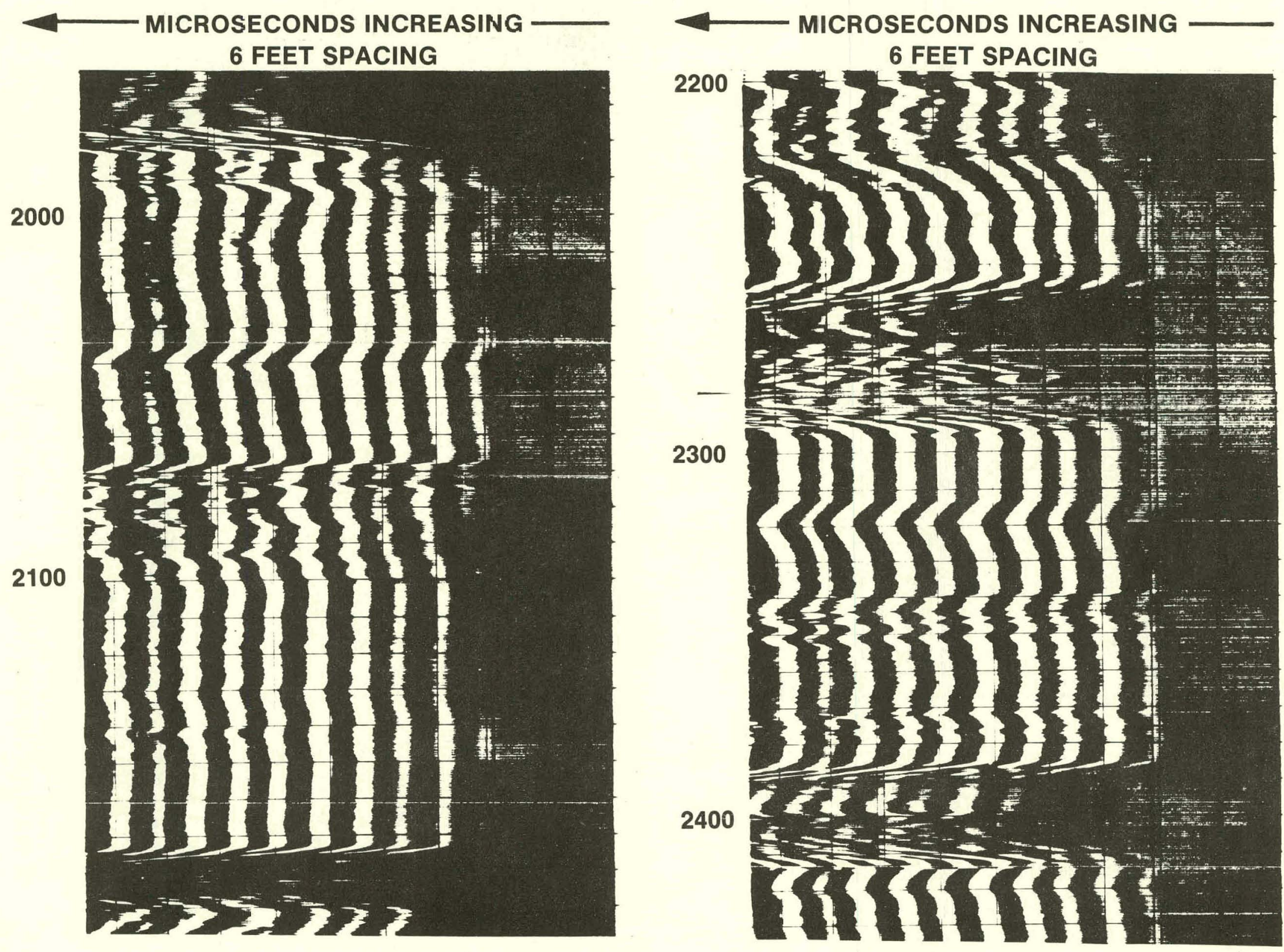

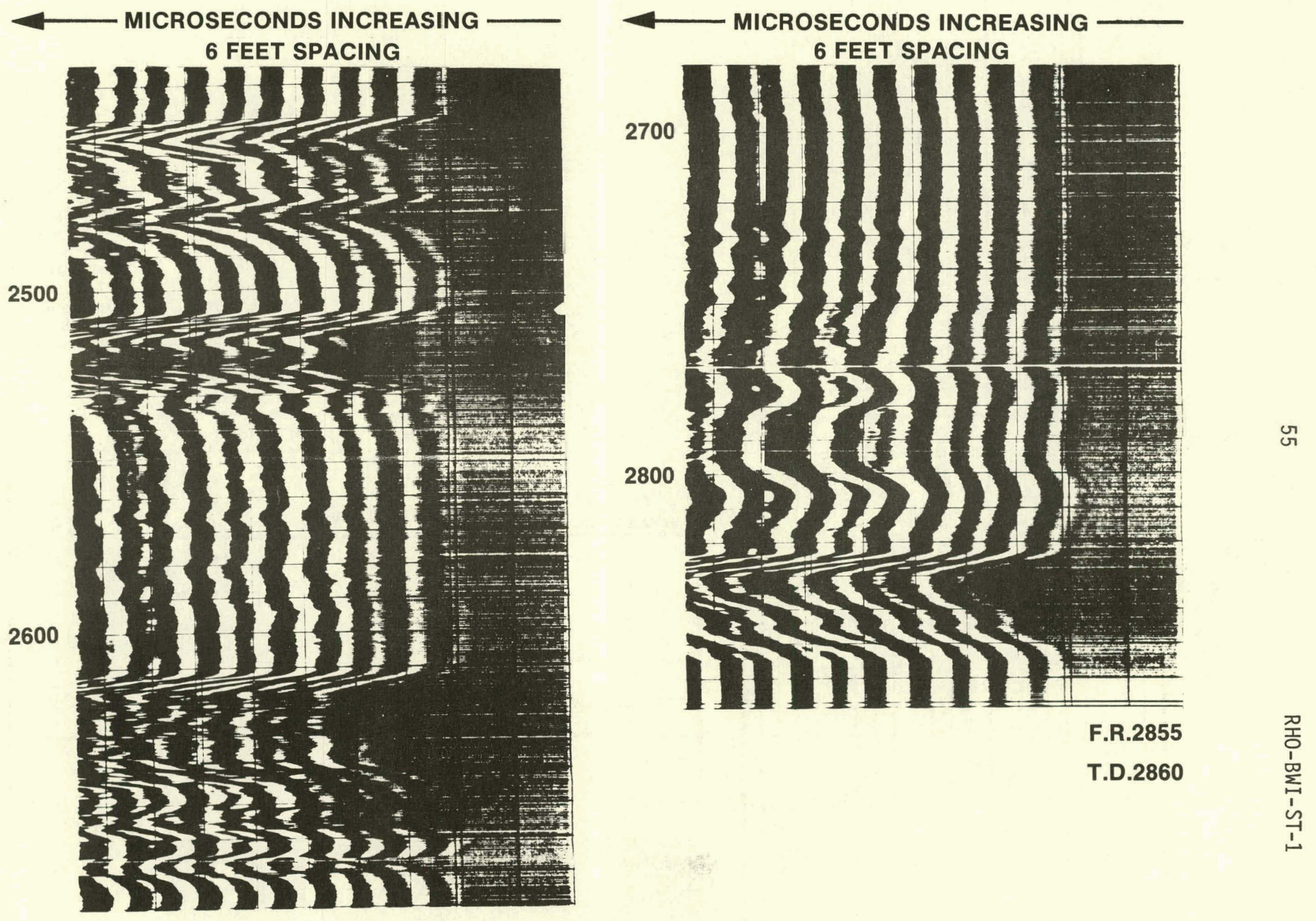


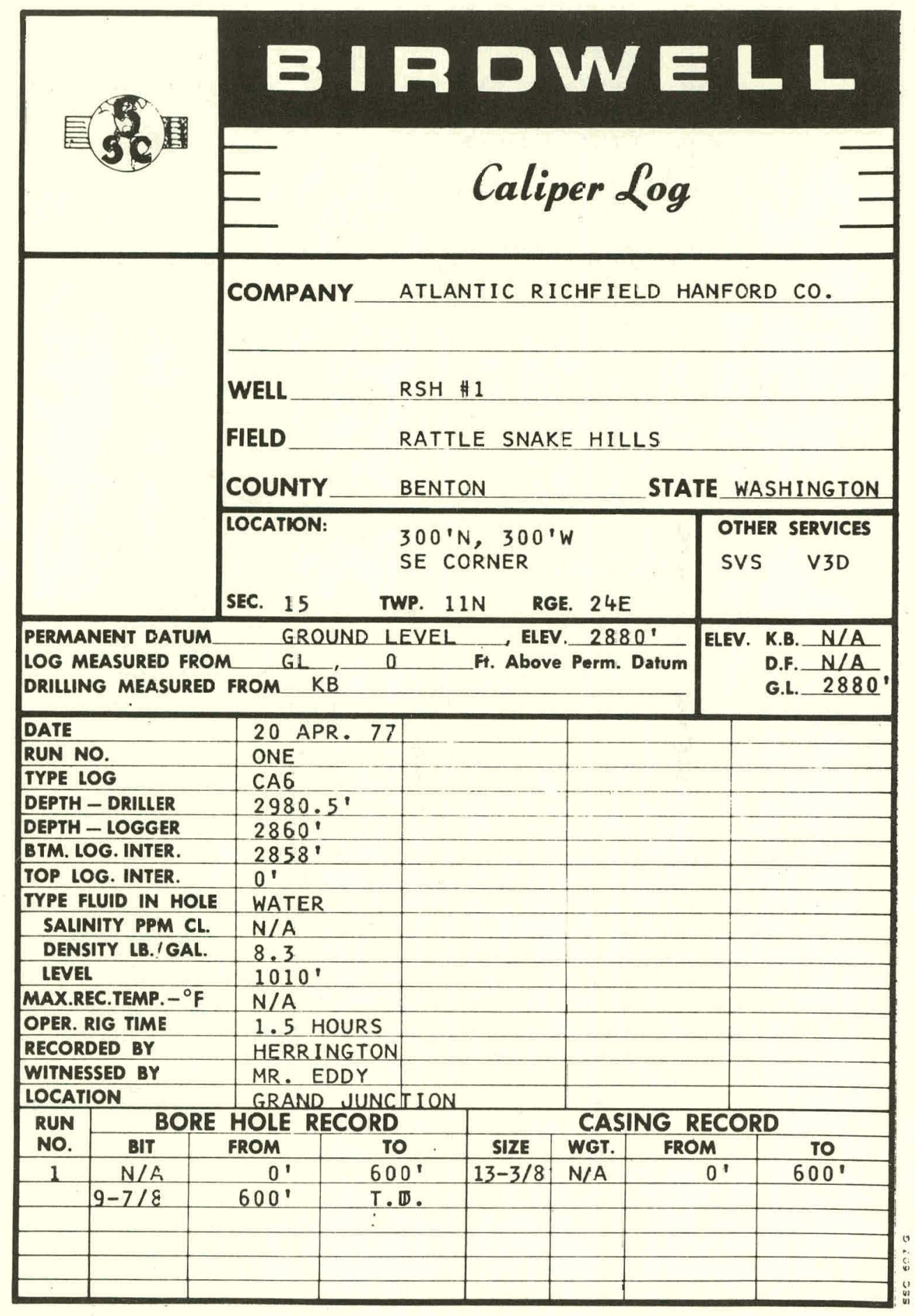

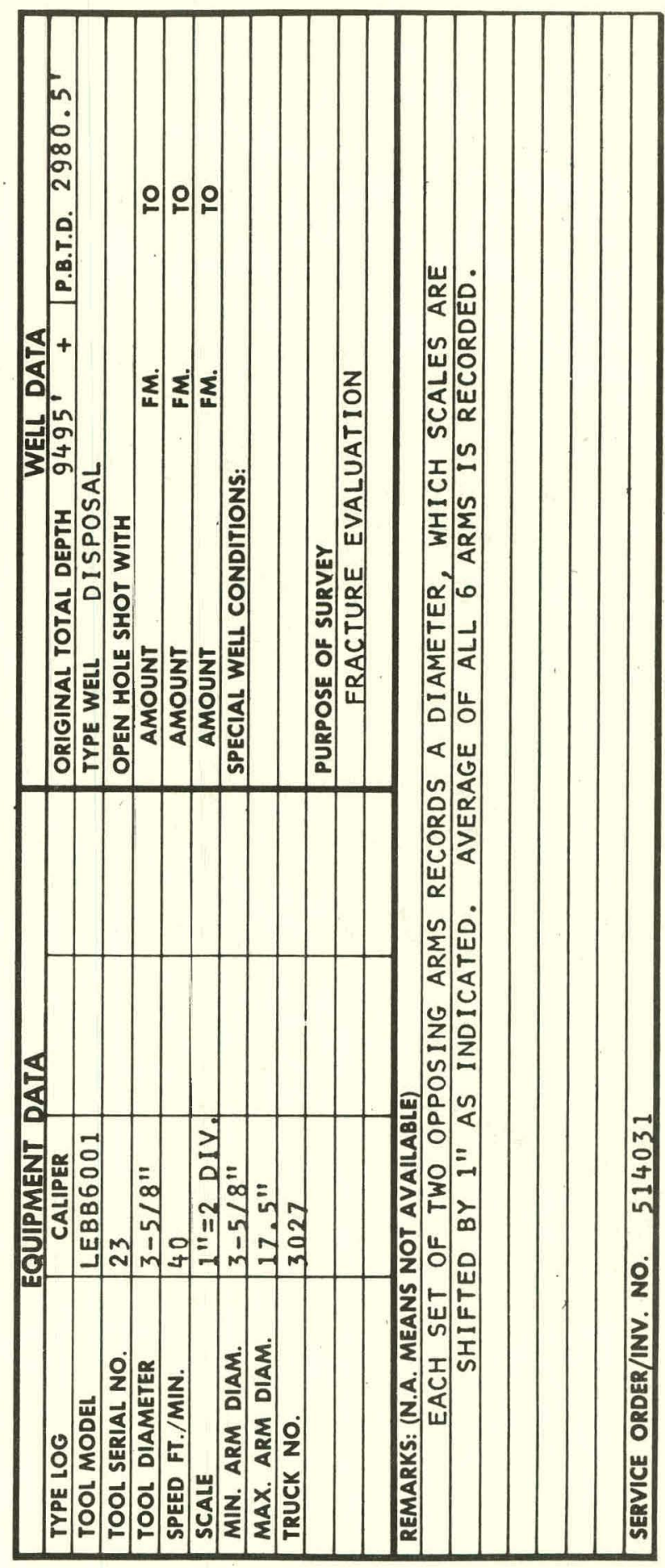




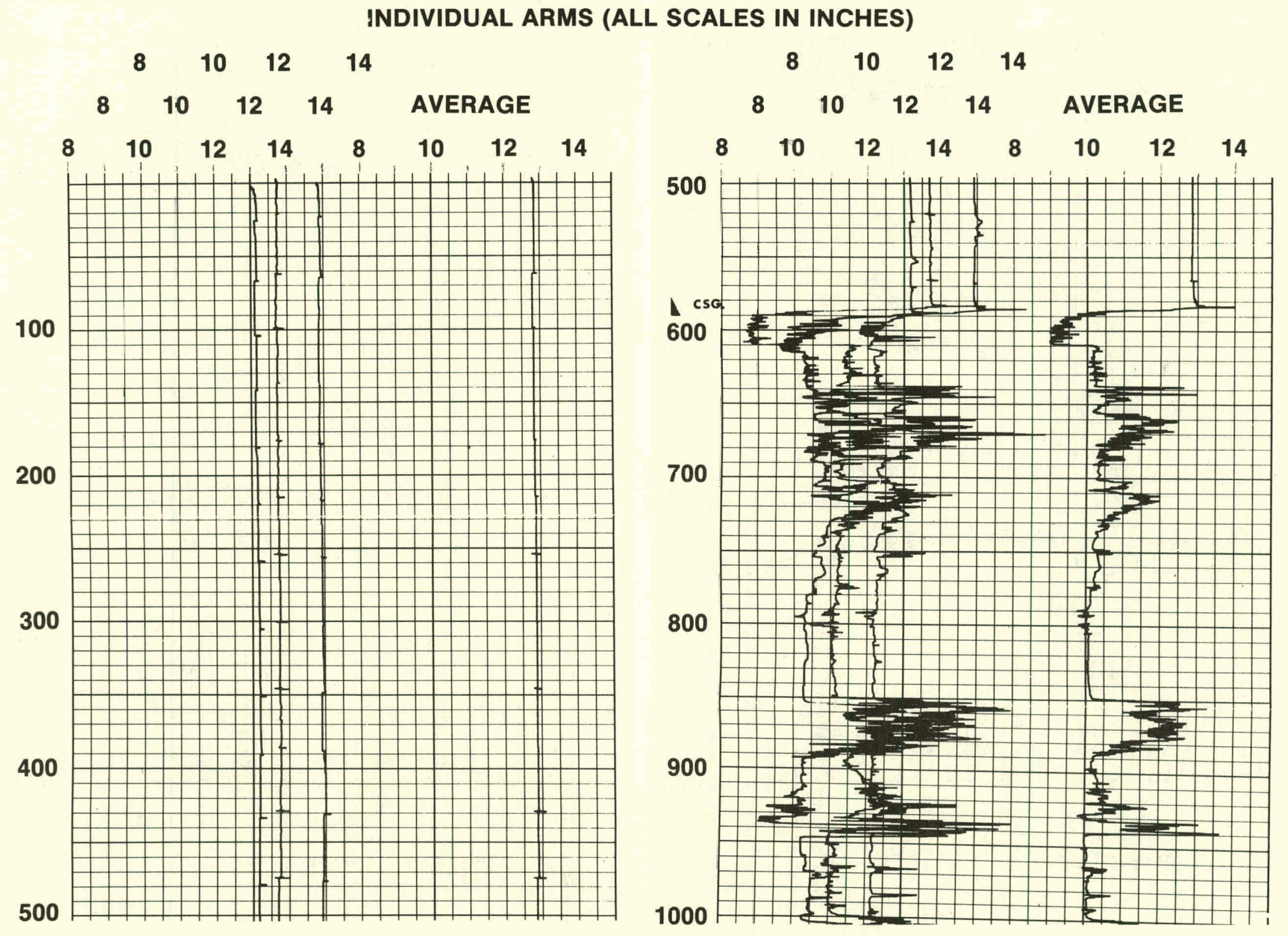


INDIVIDUAL ARMS (ALL SCALES IN INCHES)
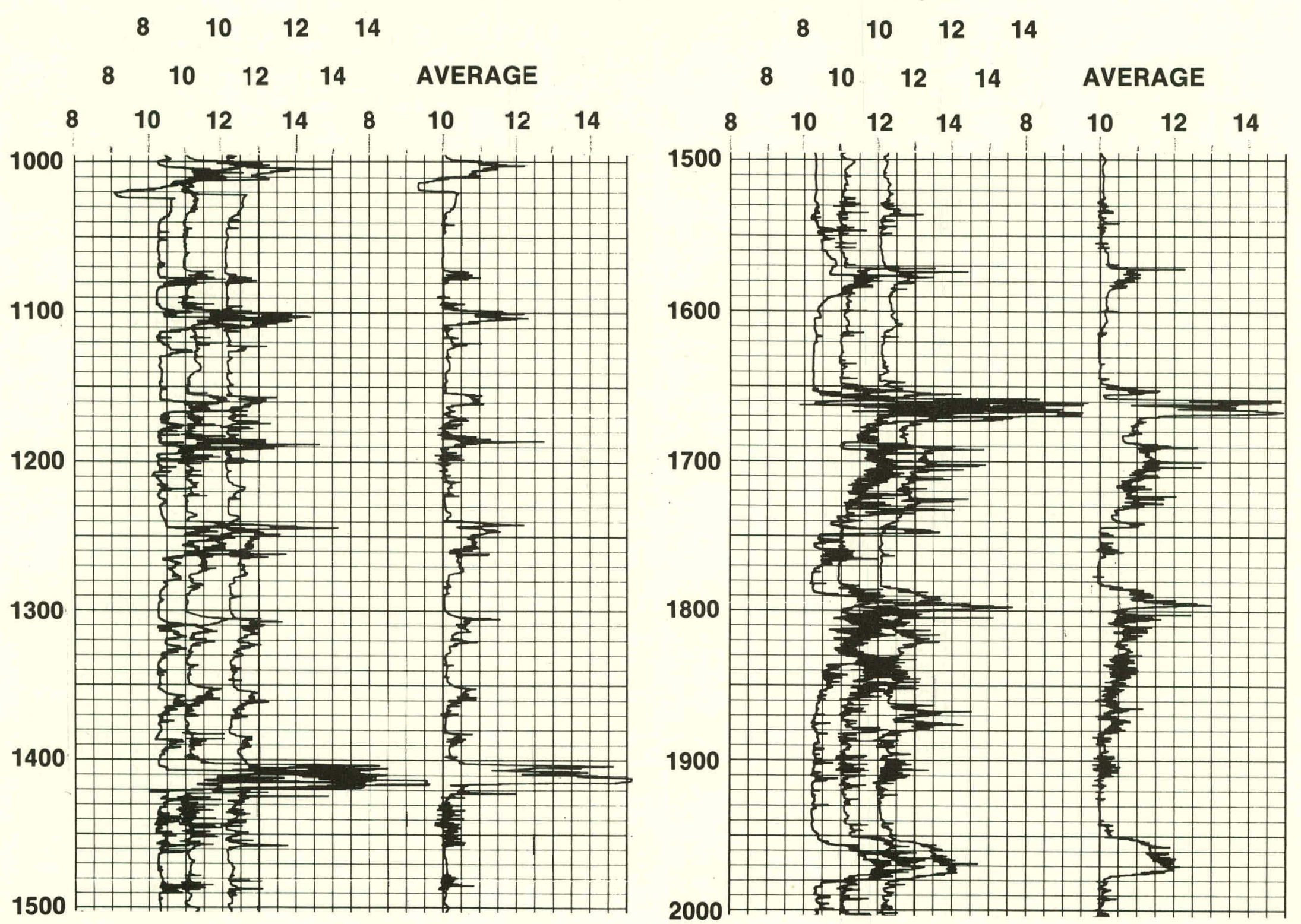
INDIVIDUAL ARMS (ALL SCALES IN INCHES)
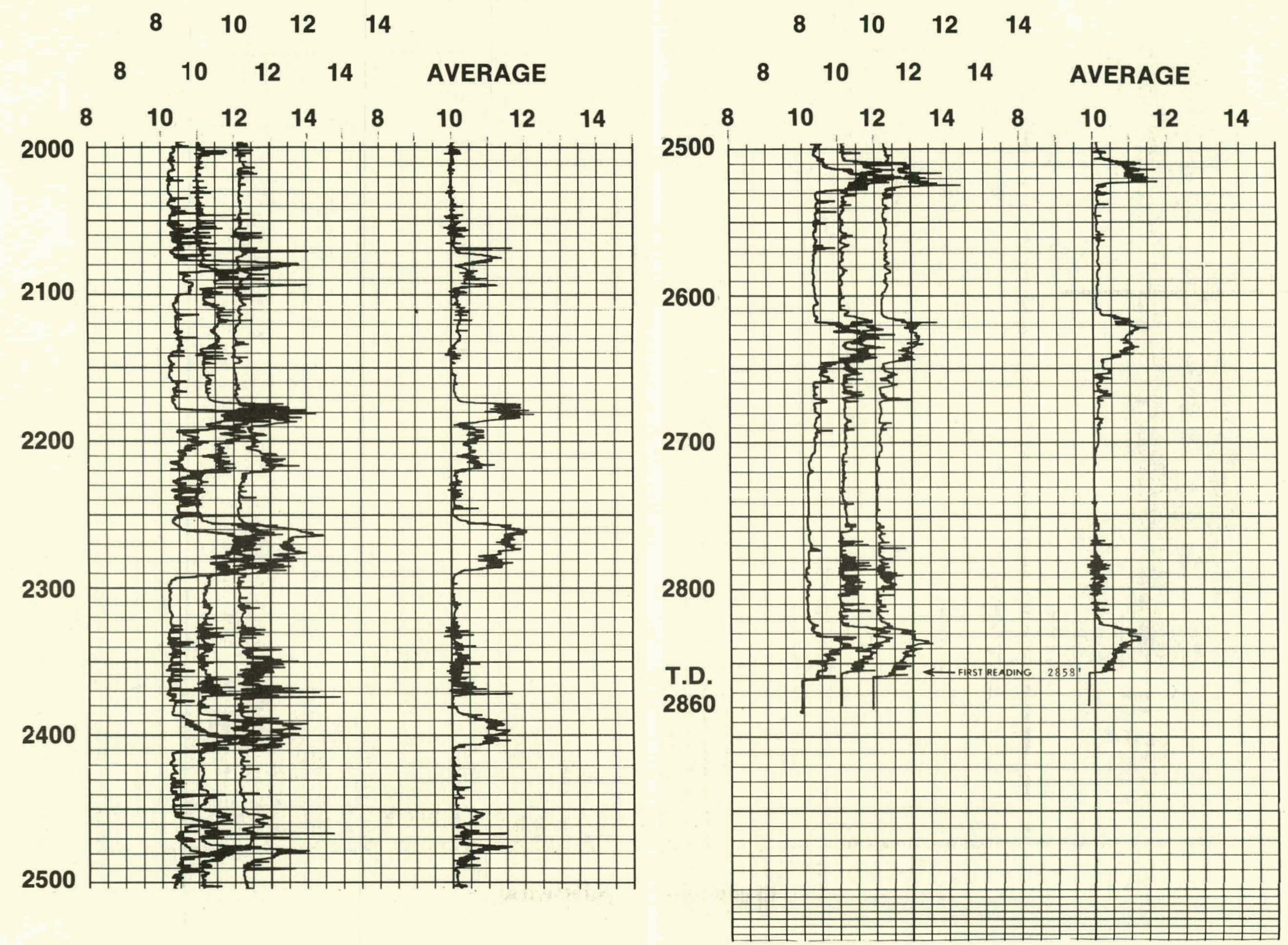


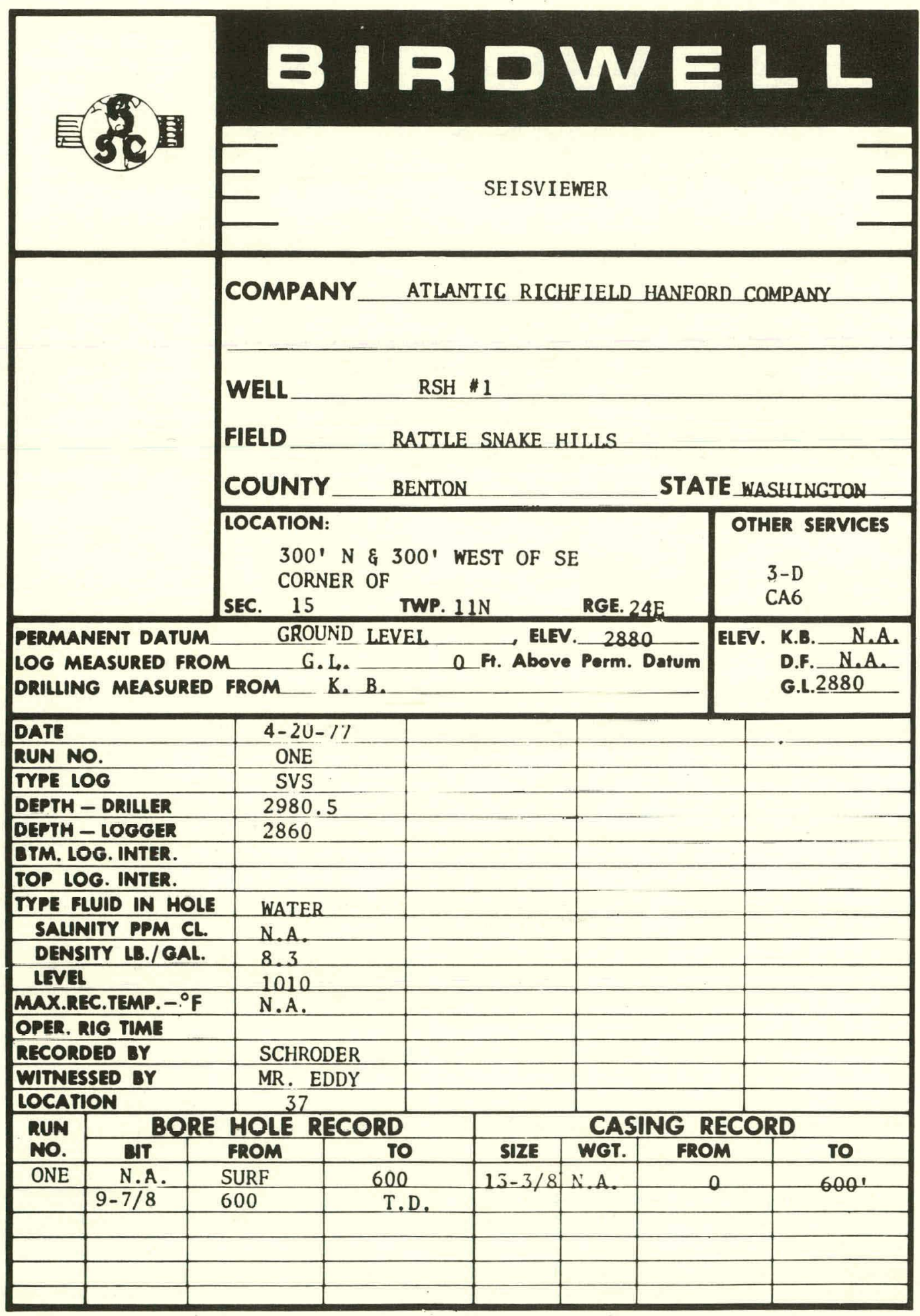

a11 depths in feet below ground level 


\section{NOT ORIENTED}
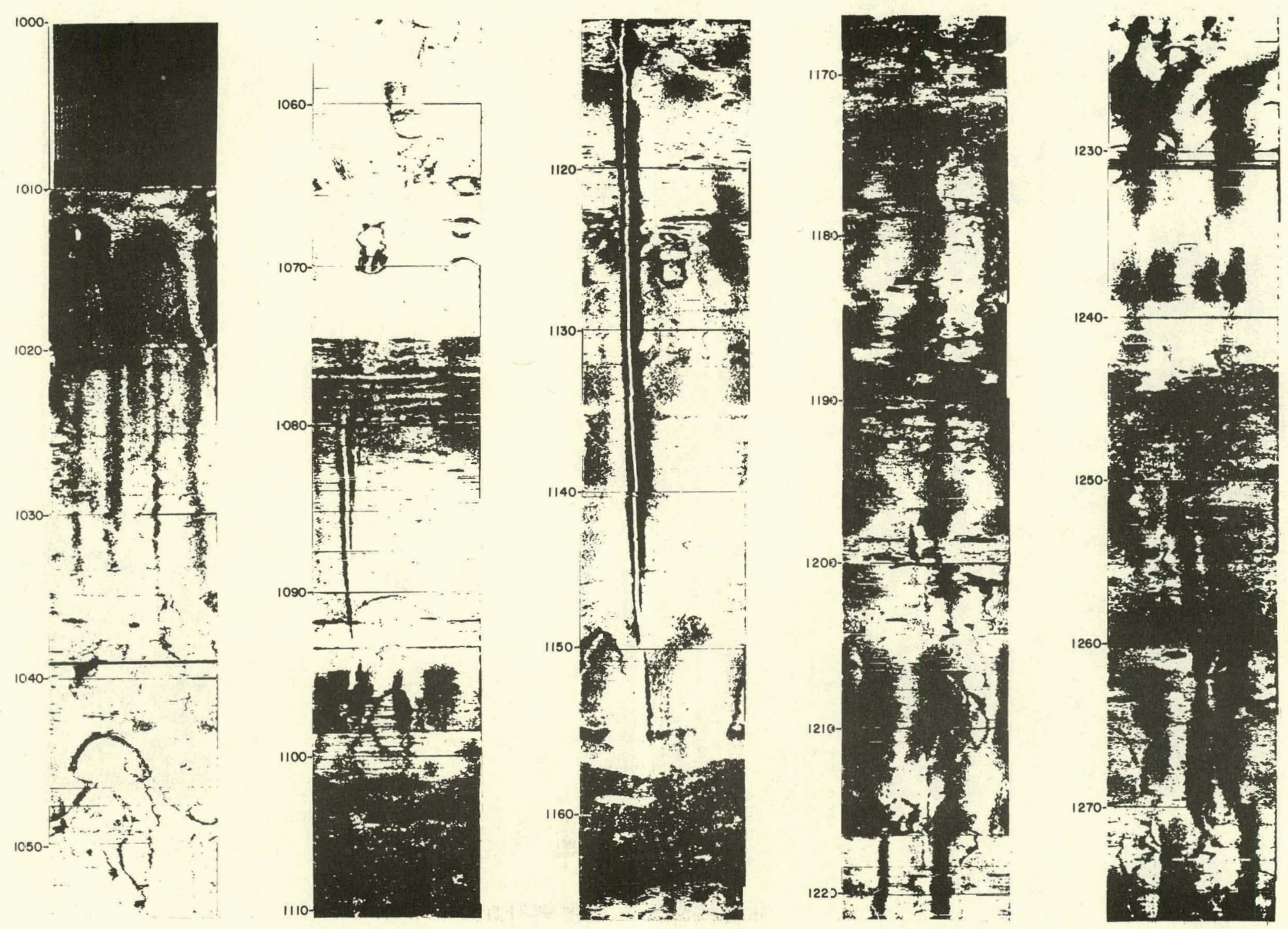

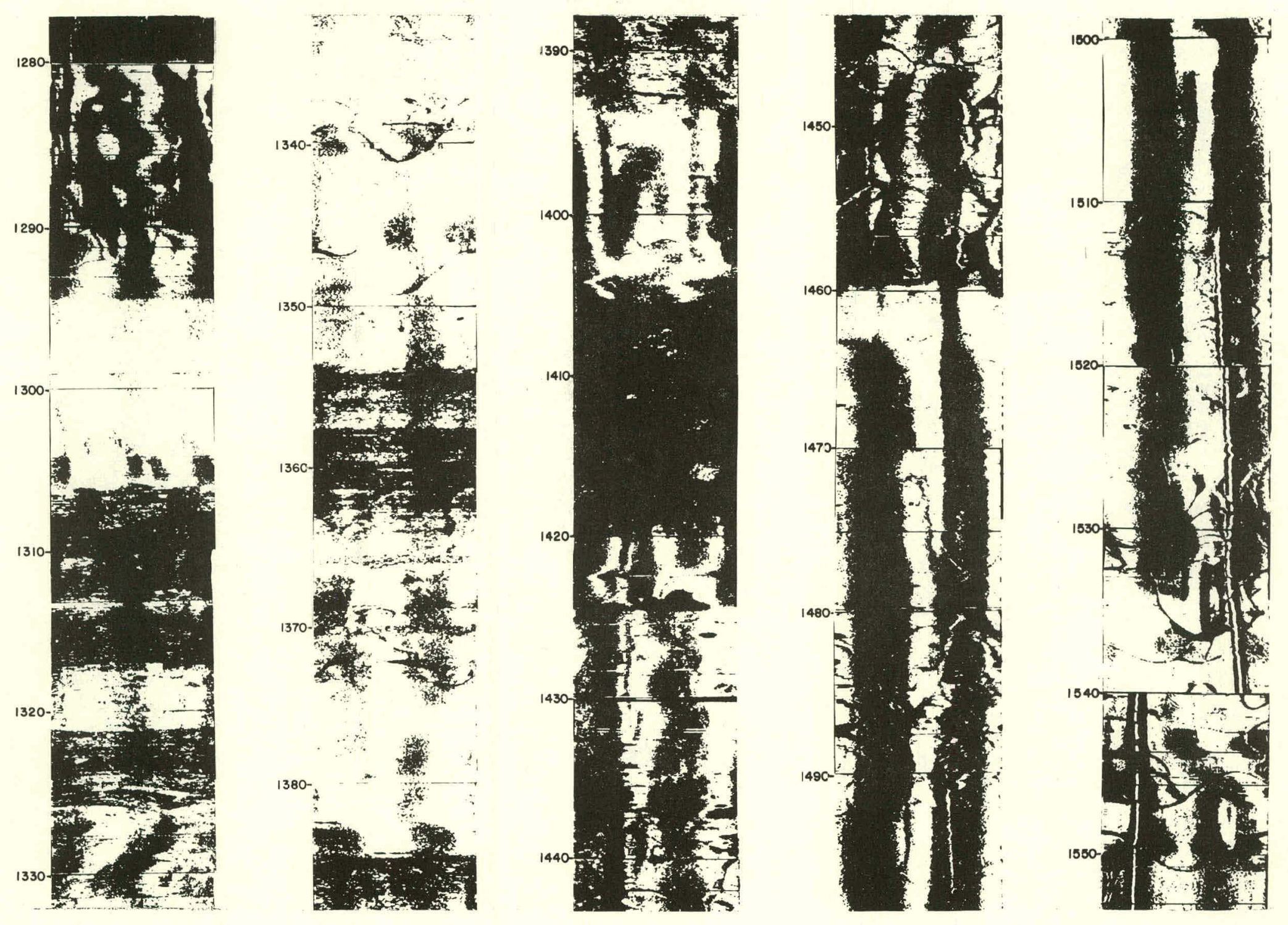

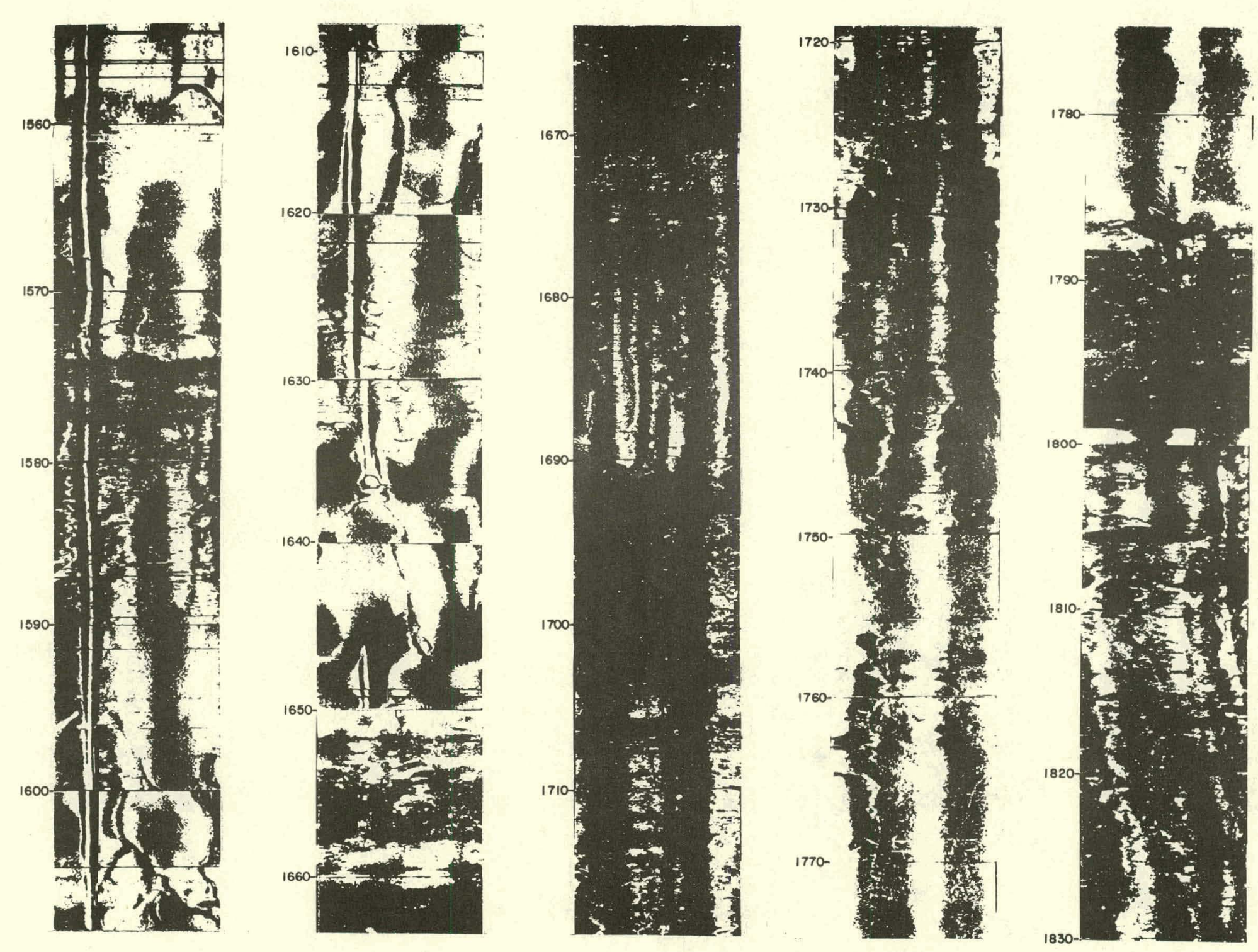

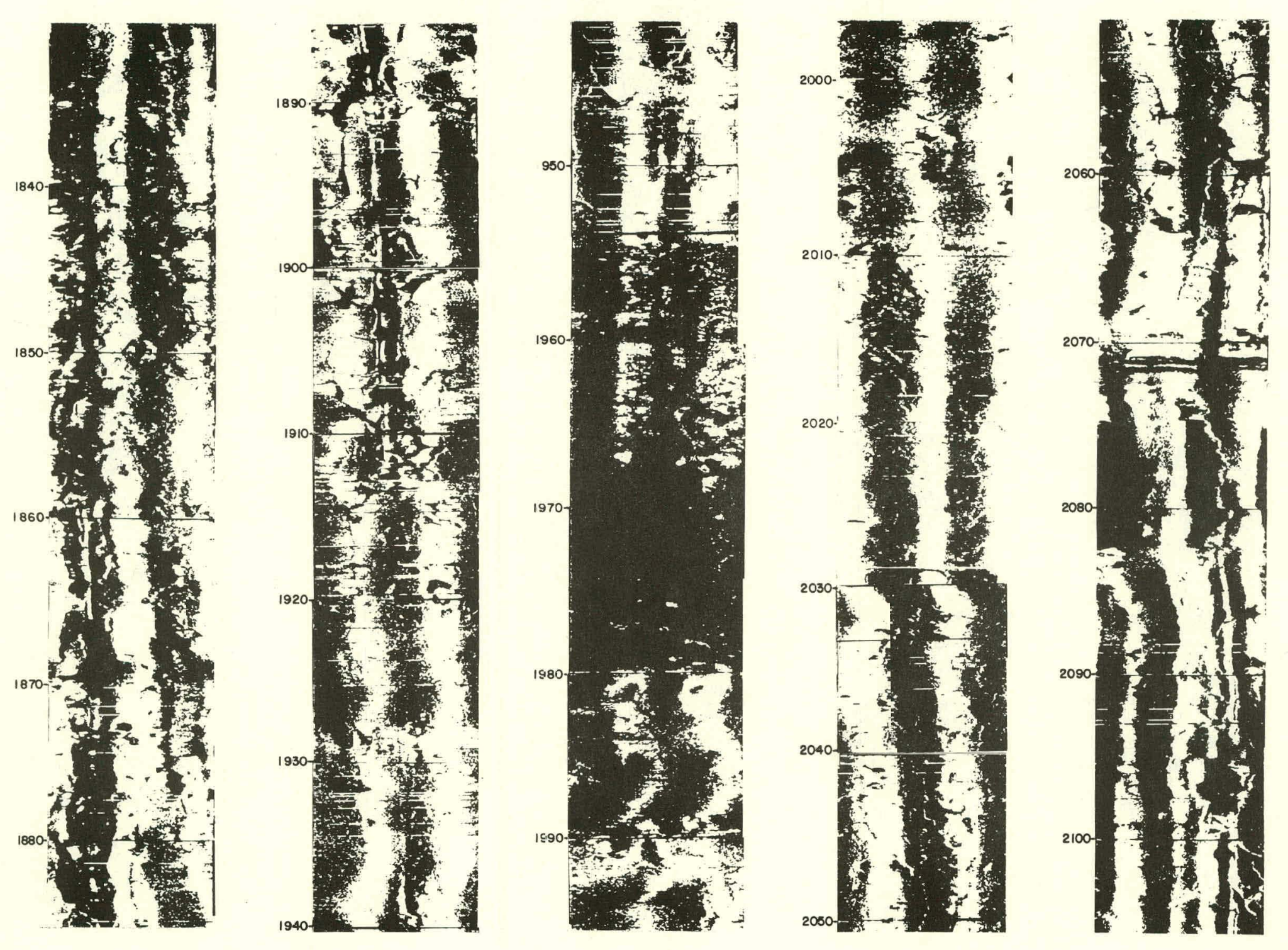

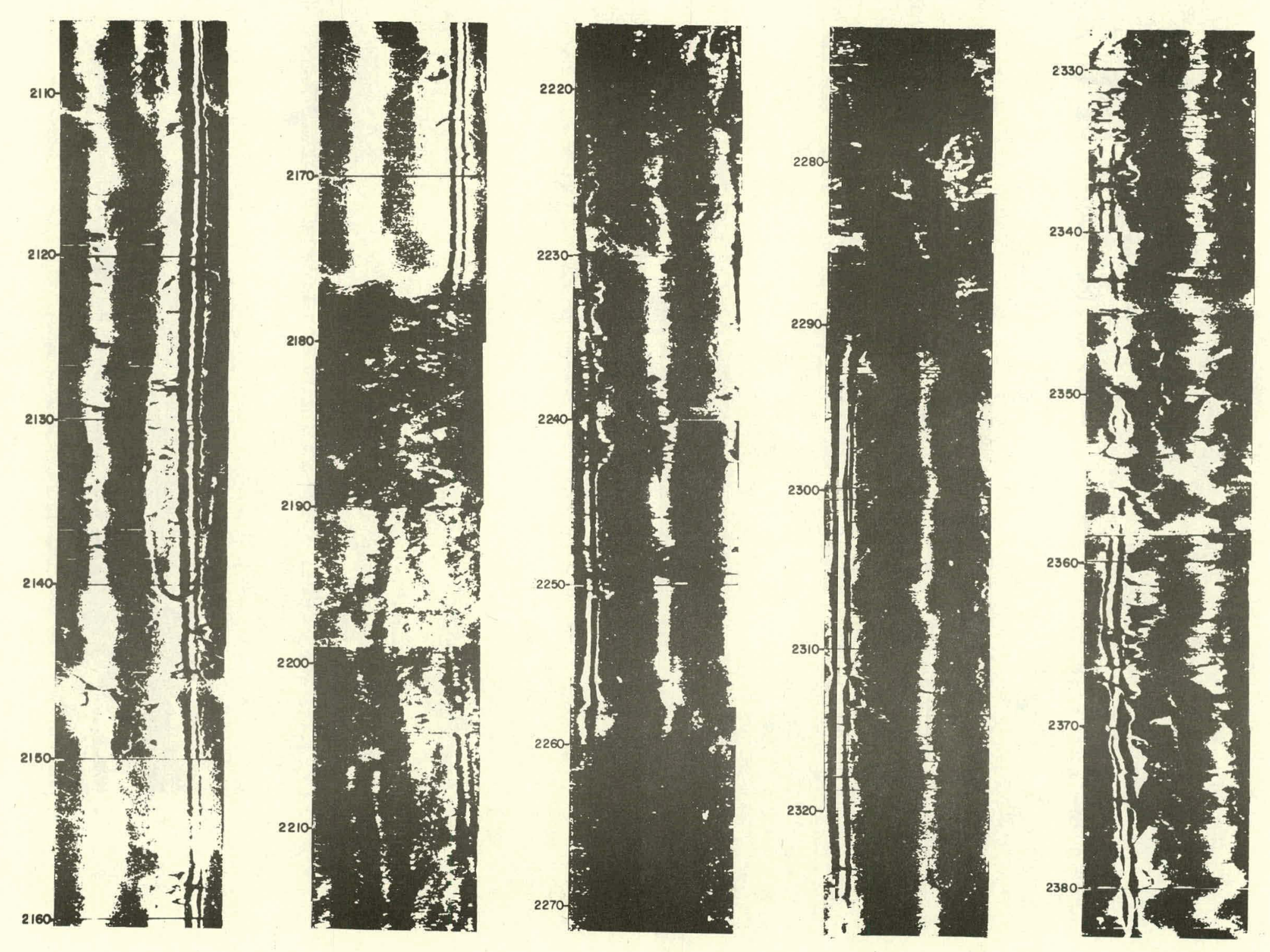

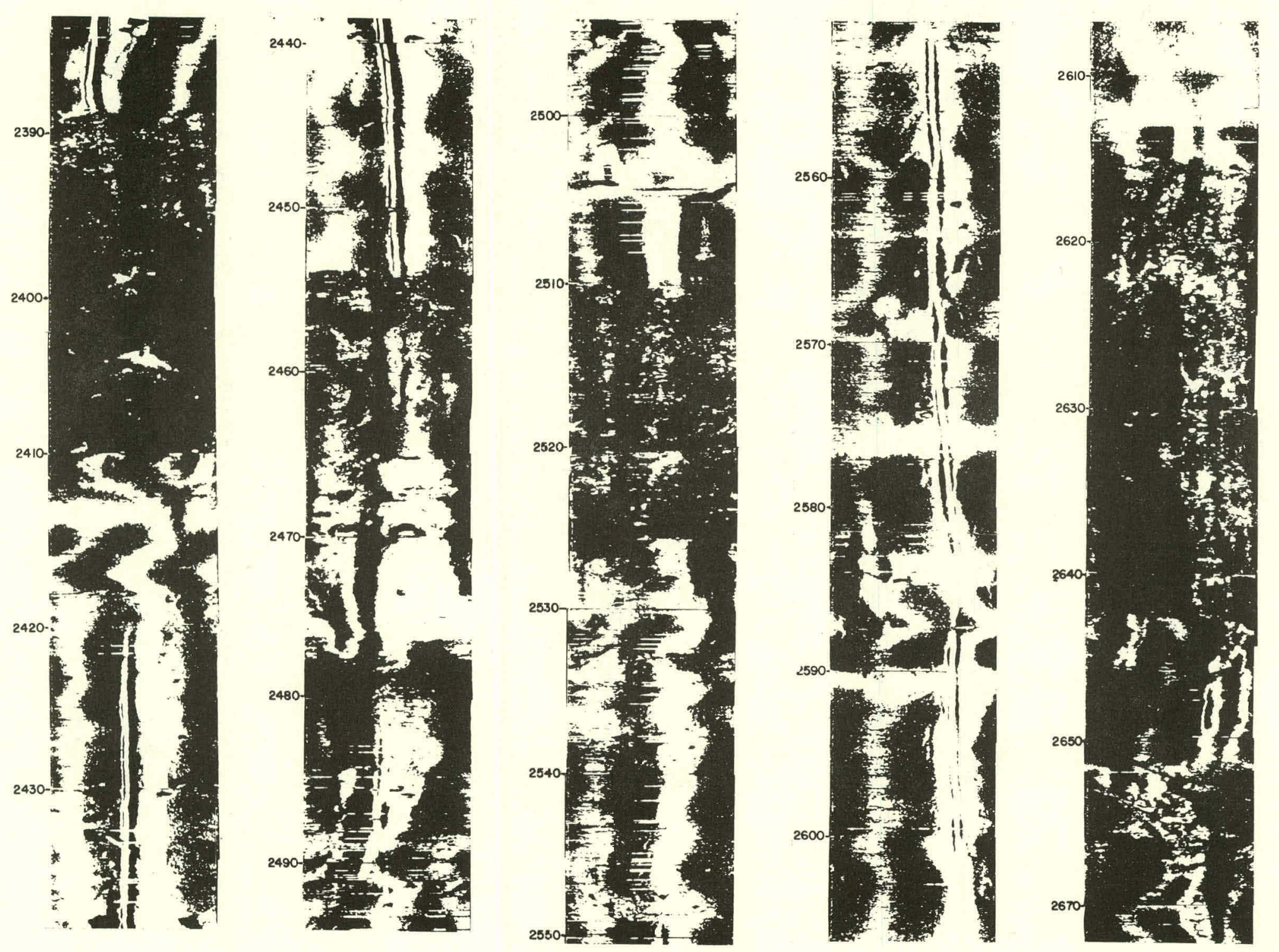

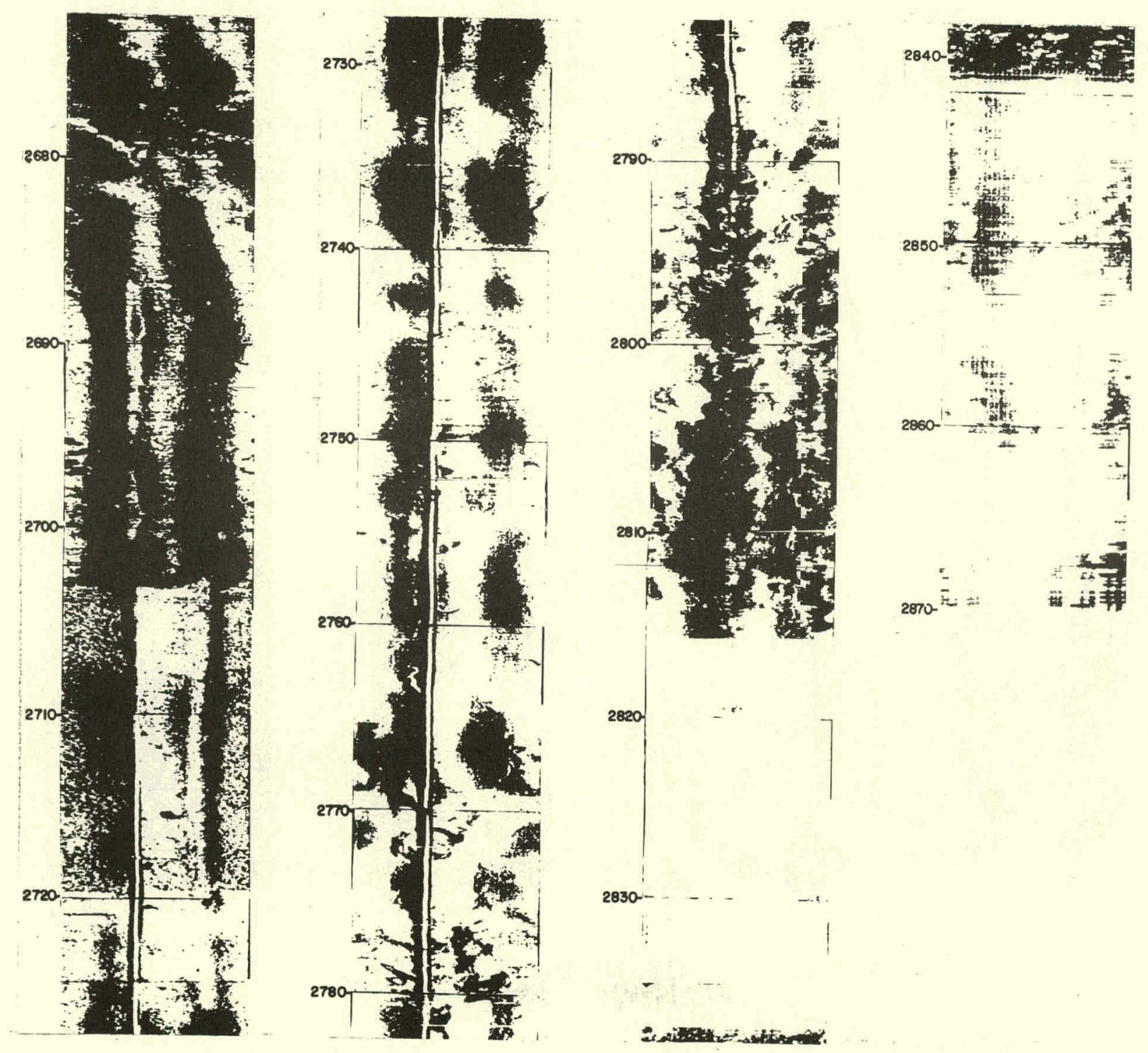
ORIENTED
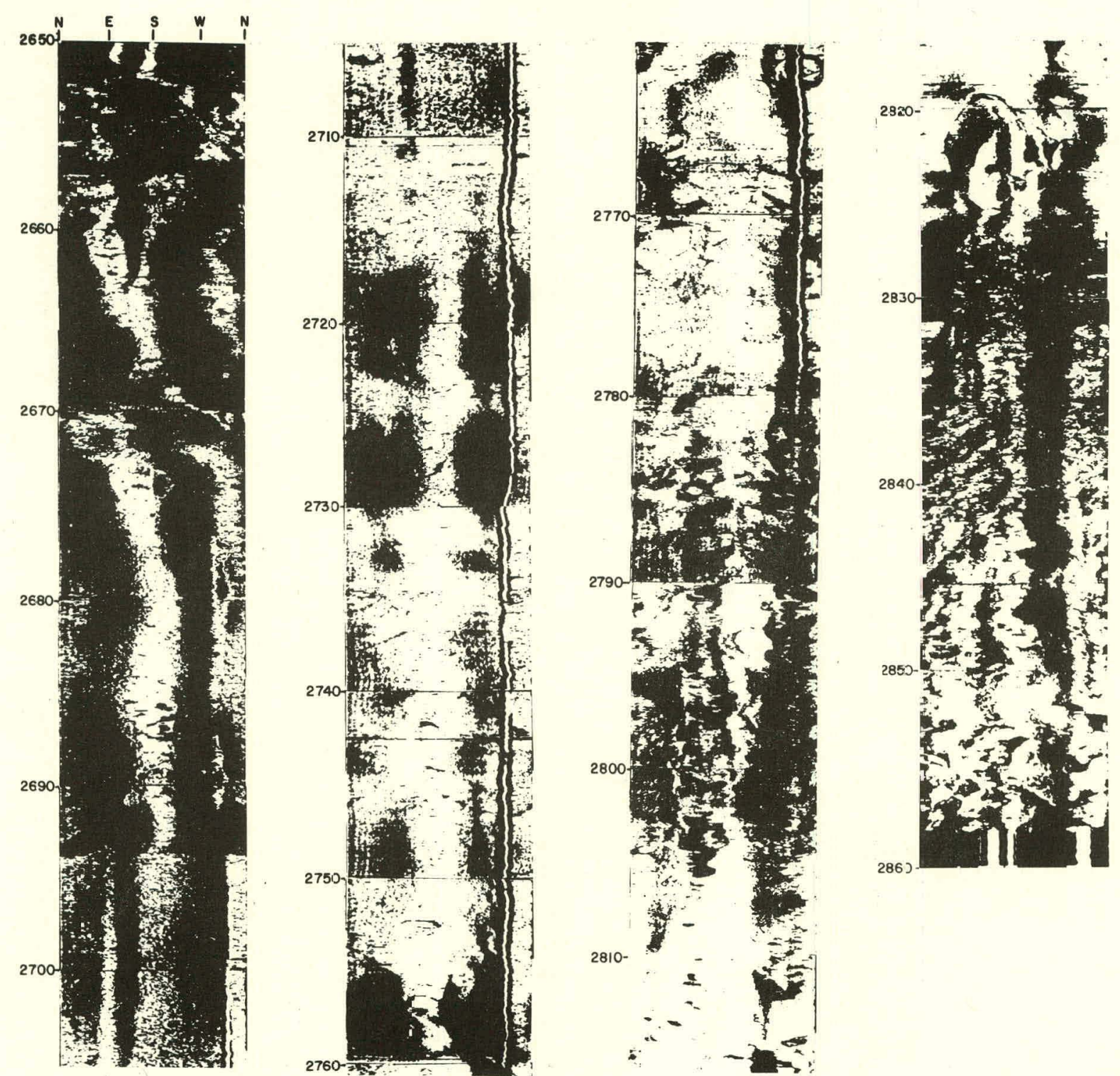
ORIENTED
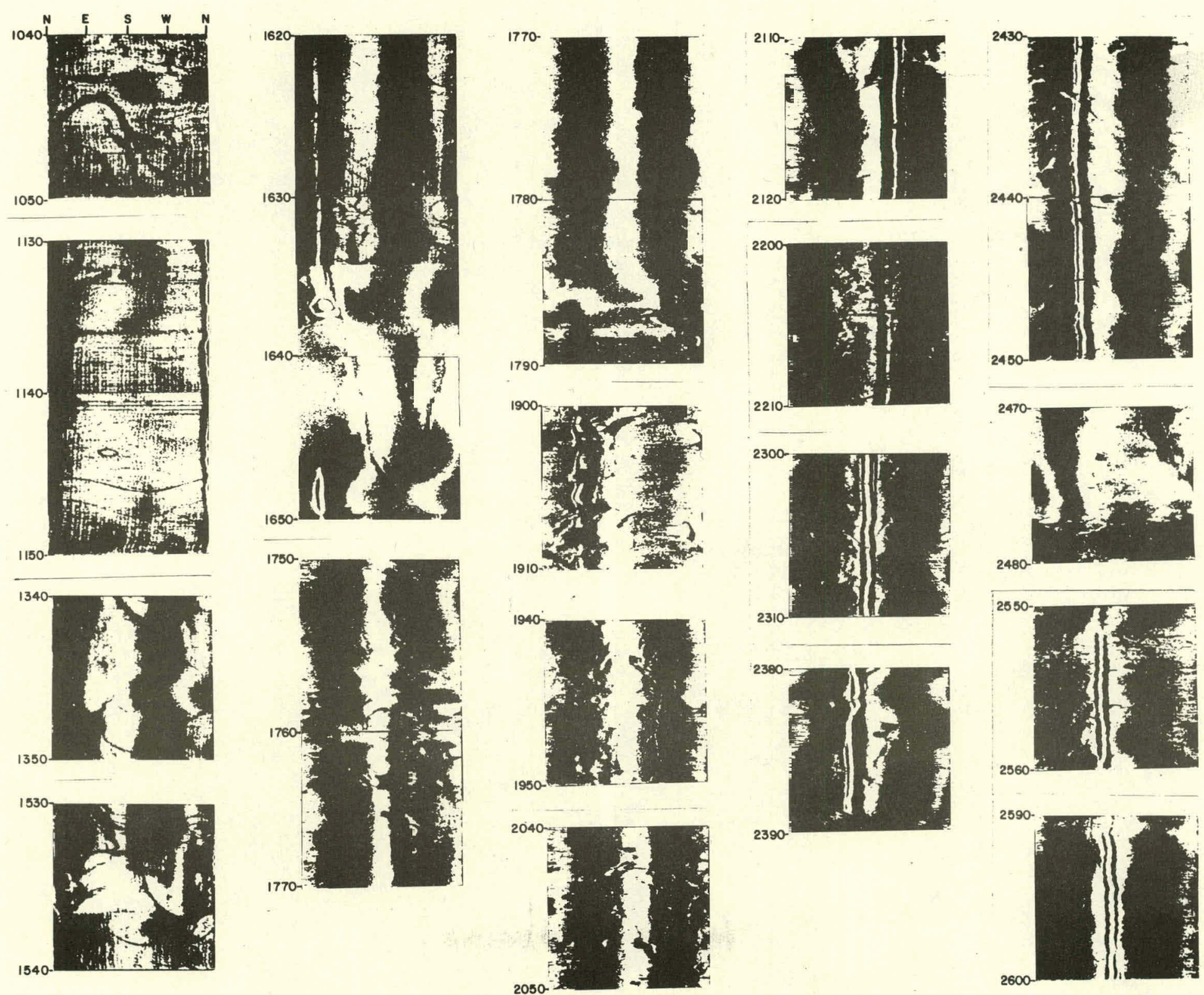

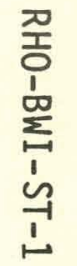


APPENDIX B

DRILLSTEM TEST DATA 
TEST 1-1 
Phone

522-1206 Area 303

\section{LYNES, INC.}

Box 712

Sterling, Colo.

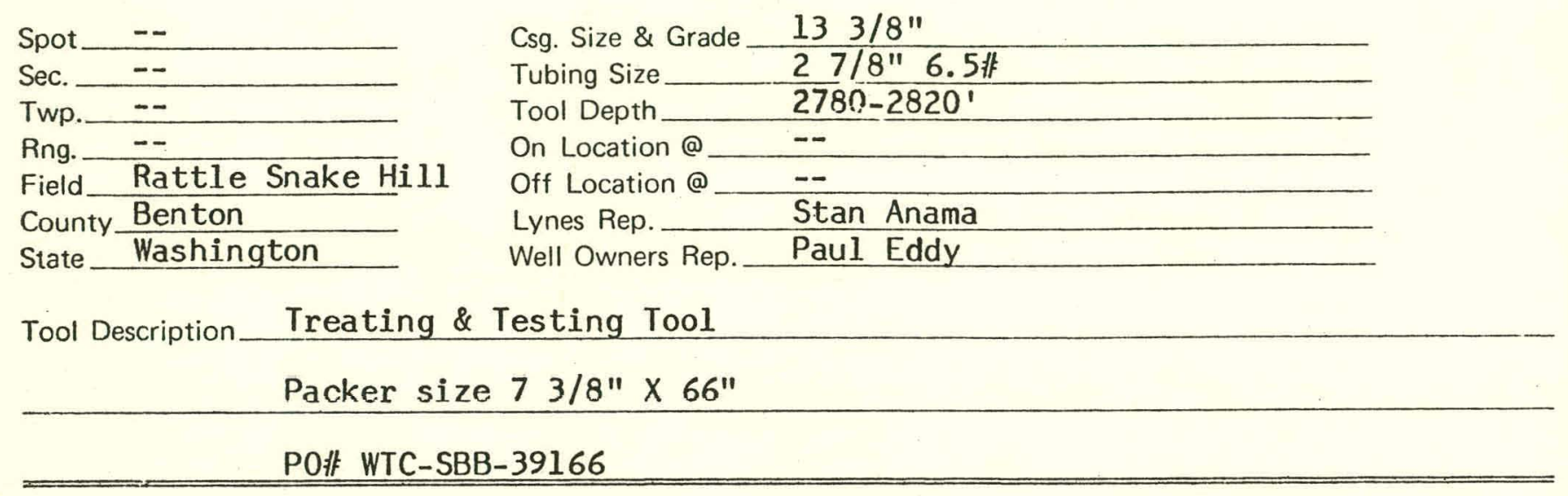

Summary:

Test 非

4-27-77

$8: 00$ AM.

$9: 40$ AM:

Filled tubing and inflated packers with 600 psig. surface pressure.

Moved tool to between position, swabbed down 1500'. Let set for 50 minutes. Continued to swab, swabbed down at 1:14 PM. Let set for 90 minutes. Ran swab to check for recovery-no recovery.

Flowing pressures in 15 minute increments on following pages. 


\section{LYNES, INC.}

Operator_Arco Hanford Co.

Lease \& No.

RSH 非

DST No. 1

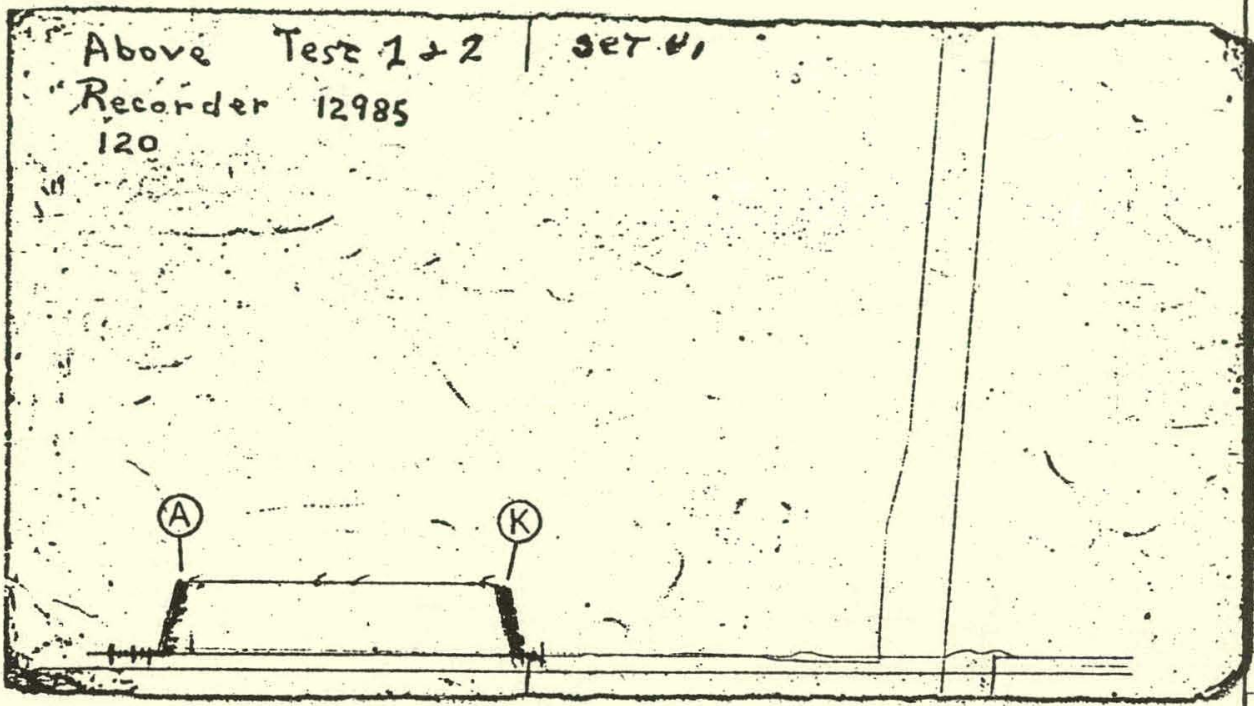

Above Interval

PRD Make Kuster K-3

No. $\frac{12985}{\text { Press }}$ Cap. $\frac{6100-@ \frac{2763^{\prime}}{\text { Corrected }}}{729}$

\begin{tabular}{ll|l}
\hline Initial Hydrostatic & A & 729
\end{tabular}

Final Hydrostatic

Initial Flow

Final Initial Flow

Initial Shut-in

Second Initial Flow

Second Final Flow

Second Shut-in

Third Initial Flow

Third Final Flow

Third Shut-in

\begin{tabular}{l|l} 
A & 722 \\
\hline
\end{tabular}

C

D $\quad-$

$--$

Pressure Below Bottom

Packer Bled To

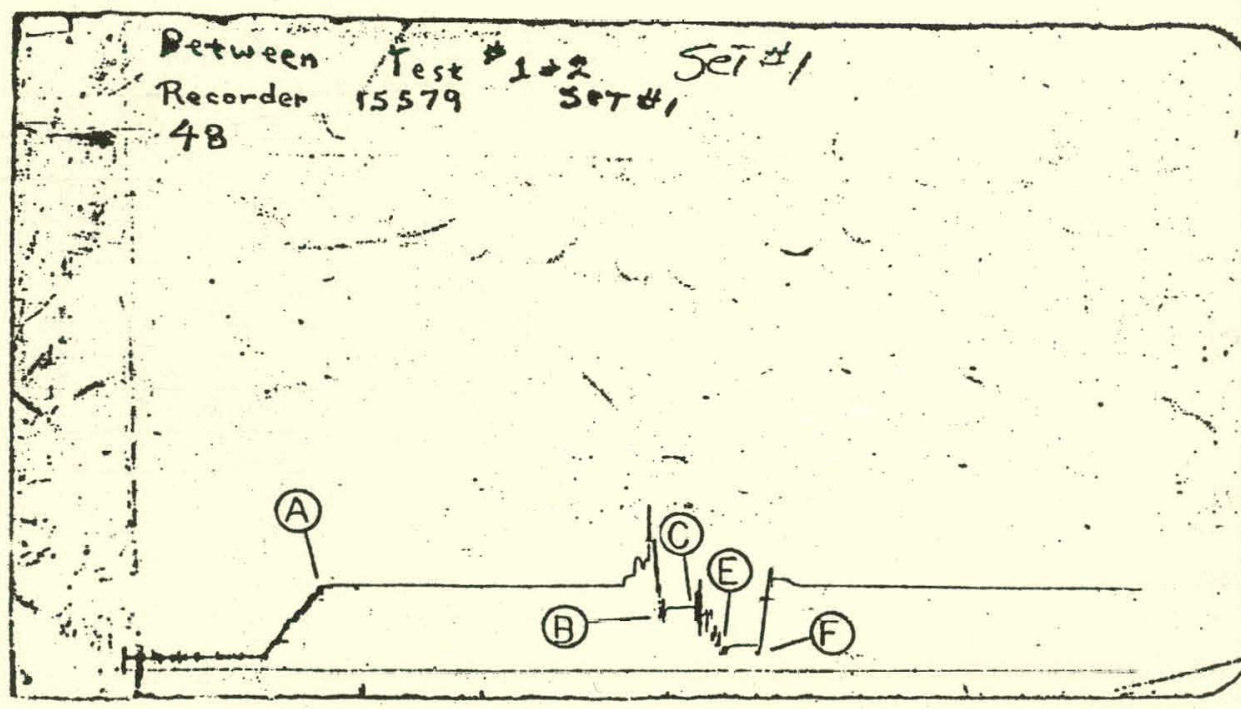

Between Interval

PRD Make Kuster K-3

No.15579 Cap.6200@ @2792'

Initial Hydrostatic

Final Hydrostatic

Initial Flow

Final Initial Flow

Initial Shut-in

Second Initial Flow

Second Final Flow

Second Shut-in

Third Initial Flow

872

Third Final Flow

Third Shut-in

A

\begin{tabular}{l|}
\hline A \\
\hline K \\
\hline B \\
\hline D \\
\hline D \\
\hline F \\
\hline F \\
\hline G \\
\hline H \\
\hline I \\
\hline J \\
\hline
\end{tabular}

555

657




\section{LYNES, INC.}

Operator Arco Hanford Co.

Lease \& No._RSH 非

DST No 1

Recorder No. 15579

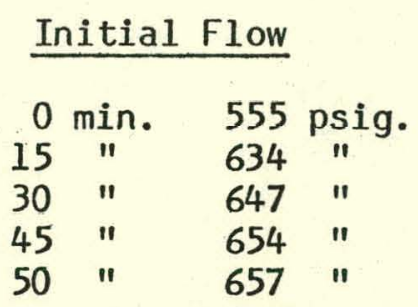

Final Flow

$\begin{array}{llll}0 & \text { min. } & 170 & \text { psig. } \\ 15 & " & 251 & " \\ 30 & " & 259 & " \\ 45 & " & 262 & " \\ 60 & " & 262 & " \\ 75 & " & 262 & " \\ 90 & \text { " } & 267 & \end{array}$


TEST 1-2 
Spot _ _-

Sec.

Csg. Size \& Grade

$133 / 8^{\prime \prime}$

Tubing Size $27 / 8$ " 6.5 非

Twp.__--

Tool Depth

2825-2860'

Ring. _. -

On Location @

$-$

Field Rattle Snake Hill

County Benton

Off Location@

Lynes Rep.

Stan Anama

State Washington

Well Owners Rep.

Paul Eddy

Tool Description__Treating \& Testing Tool

Packer size $73 / 8^{\prime \prime} \times 66^{\prime \prime}$

PO非 WTC-SBB-39166

Summary:

Test 非

$4-2 /-77$

$3: 21 \mathrm{PM}$.

4:50 PM.

Filled tubing and moved tool to below position.

Swabbed down and let set for 910 minutes.

4-28-77

$8: 00$ AM.

Ran swab to check for recovery, recovered 50 gallons of water. Filled tubing and released packers.

Flowing pressures in 15 minute increments on following pages. 


\section{LYNES, INC.}

Operator Arco Hanford Co. Lease \& No.

RSH 非1

DST No. 2

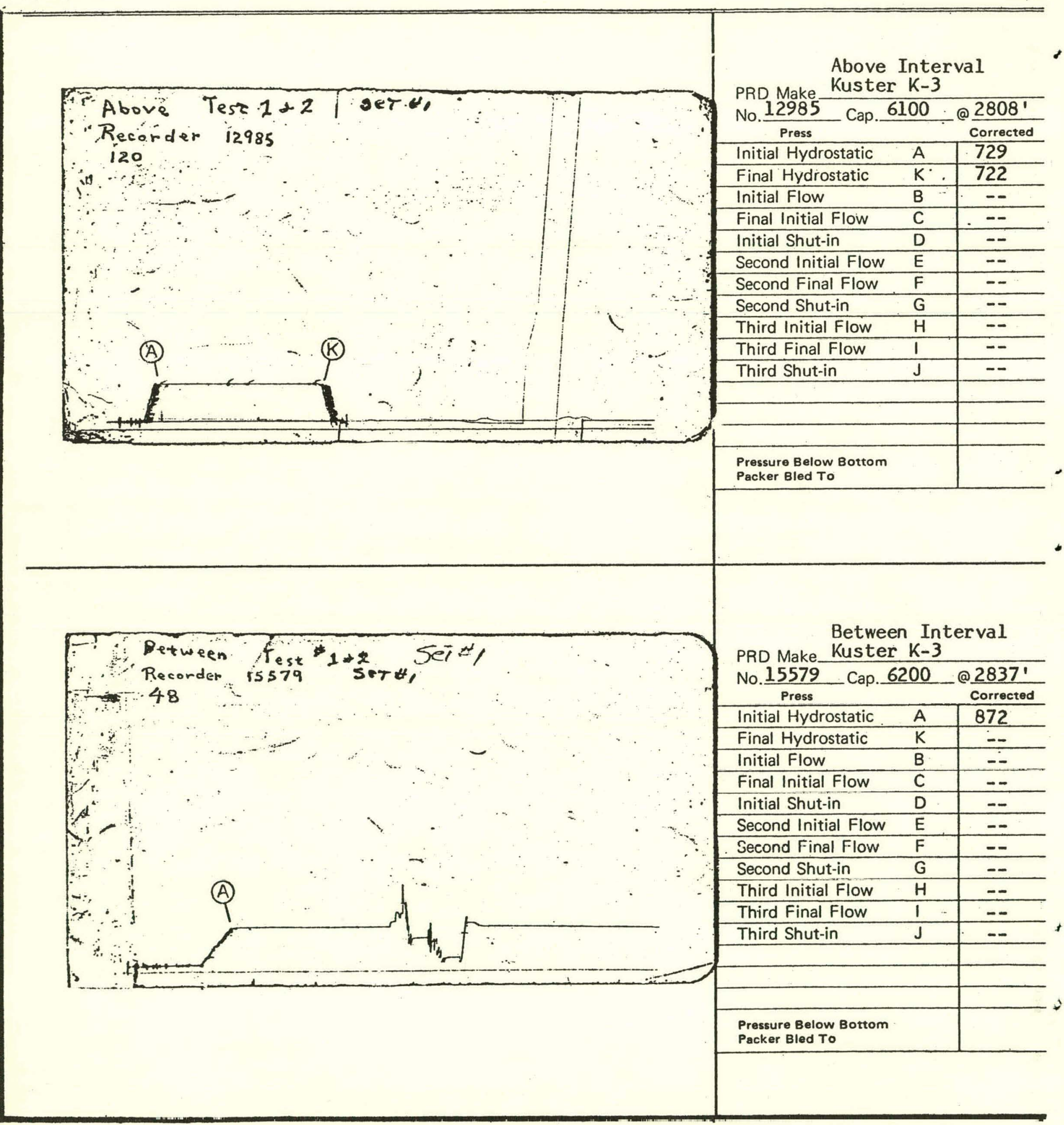




\section{LYNES, INC.}

$\checkmark$

Operator_Arco Hanford Co. Lease \& No.

RSH 非1

DST No.

2

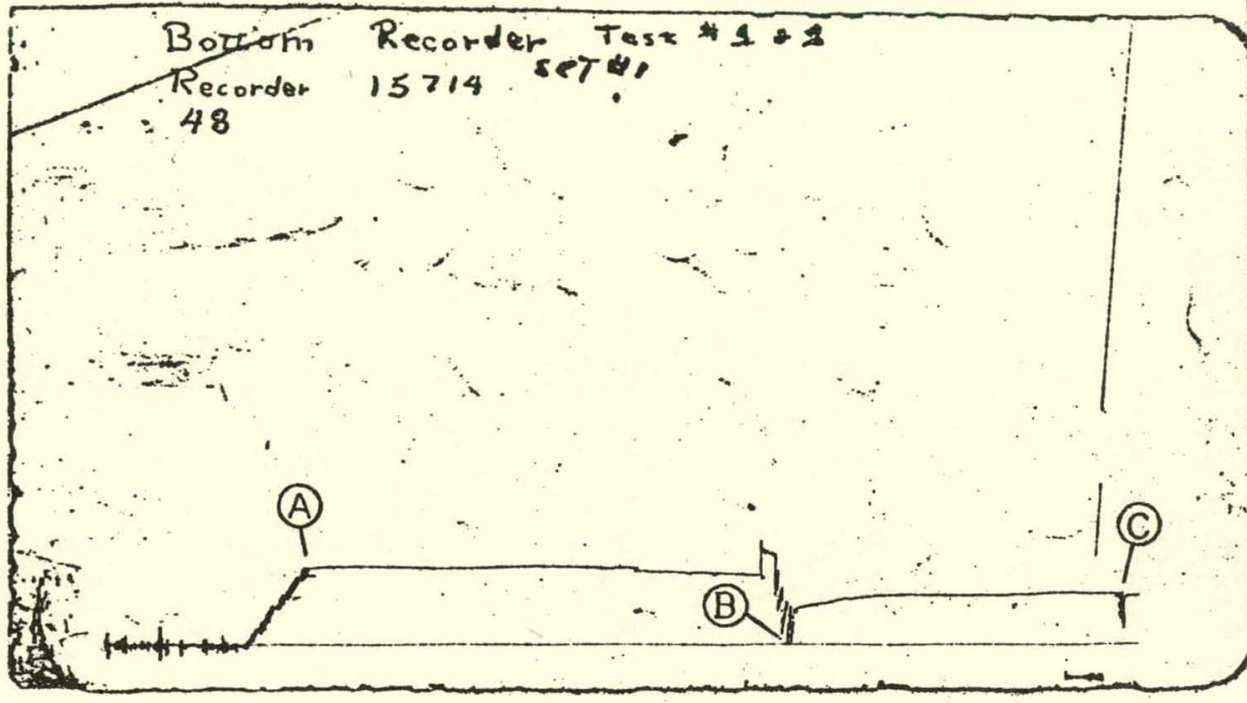

Below Interval

PRD Make Kuster K-3

No. $\frac{15714}{\text { Press }}$ Cap. $6000 @ \frac{2866^{\prime}}{\text { Corrected }}$

\begin{tabular}{|ll|l}
\hline Initial Hydrostatic & A & $\mathbf{7 5 8}$
\end{tabular}

Final Hydrostatic

Initial Flow

Final Initial Flow

Initial Shut-in

Second Initial Flow

Second Final Flow

Second Shut-in

Third Initial Flow

Third Final Flow

Third Shut-in

Pressure Below Bottom

Packer Bled To

PRD Make

\begin{tabular}{ll|l} 
No. & \multicolumn{2}{c}{ Cap. } \\
\cline { 2 - 3 } Press & & \multicolumn{1}{c}{ Corrected } \\
\hline Initial Hydrostatic & A & \\
\hline Final Hydrostatic & K & \\
\hline Initial Flow & B & \\
\hline Final Initial Flow & C & \\
\hline Initial Shut-in & D & \\
\hline Second Initial Flow & E & \\
\hline Second Final Flow & F & \\
\hline Second Shut-in & G & \\
\hline Third Initial Flow & H & \\
\hline Third Final Flow & I & \\
\hline Third Shut-in & J & \\
\hline & & \\
\hline & & \\
\hline & & \\
\hline Pressure Below Bottom & & \\
Packer Bled To & & \\
\hline
\end{tabular}




\section{LYNES, INC.}

Operator_Arco Hanford Co. Lease \& No.

RSH 非 1 DST No. 2

\section{Recorder No. 15714}

\begin{tabular}{|c|c|c|c|}
\hline 0 & $\min$. & 25 & psig \\
\hline 15 & $"$ & 359 & $"$ \\
\hline 30 & " & 376 & " \\
\hline 45 & " & 389 & " \\
\hline 60 & $"$ & 399 & $"$ \\
\hline 75 & $"$ & 409 & $"$ \\
\hline 90 & " & 414 & " \\
\hline 105 & $n$ & 422 & $"$ \\
\hline 120 & " & 434 & " \\
\hline 135 & " & 447 & " \\
\hline 150 & $"$ & 460 & " \\
\hline 165 & " & 460 & " \\
\hline 180 & " & 465 & $"$ \\
\hline 195 & " & 472 & $"$ \\
\hline 210 & $"$ & 477 & $"$ \\
\hline 22.25 & " & 482 & $"$ \\
\hline 240 & " & 487 & $"$ \\
\hline 255 & " & 487 & " \\
\hline 270 & " & 487 & $"$ \\
\hline 285 & " & 492 & " \\
\hline 300 & $"$ & 492 & $"$ \\
\hline 315 & " & 495 & $"$ \\
\hline 330 & " & 495 & " \\
\hline 345 & " & 495 & " \\
\hline 360 & $"$ & 492 & " \\
\hline 375 & " & 492 & ." \\
\hline 390 & " & 492 & " \\
\hline 405 & $"$ & 493 & $"$ \\
\hline 420 & $"$ & 493 & $"$ \\
\hline 435 & $"$ & 490 & $"$ \\
\hline 450 & " & 490 & $"$ \\
\hline
\end{tabular}

\begin{tabular}{|c|c|c|c|}
\hline 465 & nin. & 490 & psig \\
\hline 480 & & 490 & \\
\hline 495 & " & 490 & " \\
\hline 510 & " & 492 & $"$ \\
\hline 525 & " & 492 & $"$ \\
\hline 540 & " & 492 & $"$ \\
\hline 555 & " & 492 & " \\
\hline 570 & " & 492 & " \\
\hline 585 & " & 492 & " \\
\hline 600 & " & 492 & " \\
\hline 615 & $"$ & 500 & " \\
\hline 630 & $1 "$ & 503 & " \\
\hline 645 & $"$ & 503 & $"$ \\
\hline 660 & " & 503 & " \\
\hline 675 & " & 503 & " \\
\hline 690 & $"$ & 508 & " \\
\hline 705 & " & 510 & " \\
\hline 720 & " & 515 & " \\
\hline 735 & " & 518 & " \\
\hline 750 & " & 518 & " \\
\hline 765 & " & 518 & 11 \\
\hline 780 & " & 518 & " \\
\hline 795 & " & 515 & $"$ \\
\hline 810 & " & 514 & " \\
\hline 825 & " & 513 & " \\
\hline 840 & " & 510 & " \\
\hline 855 & $"$ & 508 & $"$ \\
\hline 870 & " & 508 & " \\
\hline 885 & $"$ & 508 & $"$ \\
\hline 900 & " & 508 & " \\
\hline 910 & $"$ & 508 & " \\
\hline
\end{tabular}




\section{TEST 1-2}

Water Pressures Below Packers*

\begin{tabular}{ll} 
Time (Min) & $\underline{\text { PSIG }}$ \\
\hline 0 & 351.1 \\
55 & 407.6 \\
60 & 411.5 \\
100 & 445.5 \\
230 & 472.9 \\
370 & 479.8 \\
595 & 485.0 \\
970 & 505.0
\end{tabular}

*Electric tape measurement. 
RHO-BWI-ST-1

TEST 1-3

4 


\begin{tabular}{|c|c|}
\hline Spot_____ & Csg. Size \& Grade \\
\hline Sec. & $27 / 8^{\prime \prime} 6.5$ 非 \\
\hline Twp.__ & $2700-2770^{\prime}$ \\
\hline Rng. & On Location @_ \\
\hline Field Rattle Snake Hill & Off Location@_ \\
\hline County Benton & Lynes Rep. \\
\hline State Washington & Well Owners Rep. \\
\hline
\end{tabular}

Tool Description__ Treating \& Testing Tool

Packer size $73 / 8^{\prime \prime} \times 66^{\prime \prime}$

PON WTC-SBB-39166

Summary: Test 非3

4-29-77

$9: 3 \cap$ AM.

Packers in place, filled tubing to inflate, inflated packers with 500 psig. surface pressure.

$3: 51$ PM.

Moved tool to between position and began swabbing. Swabbed down $2000^{\prime}$ and let set for 10 minutes, continued swabbing. Swabbed down at 5:10 PM. Left in open position for 3770 minutes.

$5-2-77$

$8: 43 \mathrm{AM}$.

Ran swab to check recovery. Recovered 50 gallons of water. Filled tubing.

Flowing pressures in 15 minute increments on following pages. 


\section{LYNES, INC.}

Operator Arco Hanford Co.

Lease \& No. RSH 非

DST No. 3

$\longrightarrow$

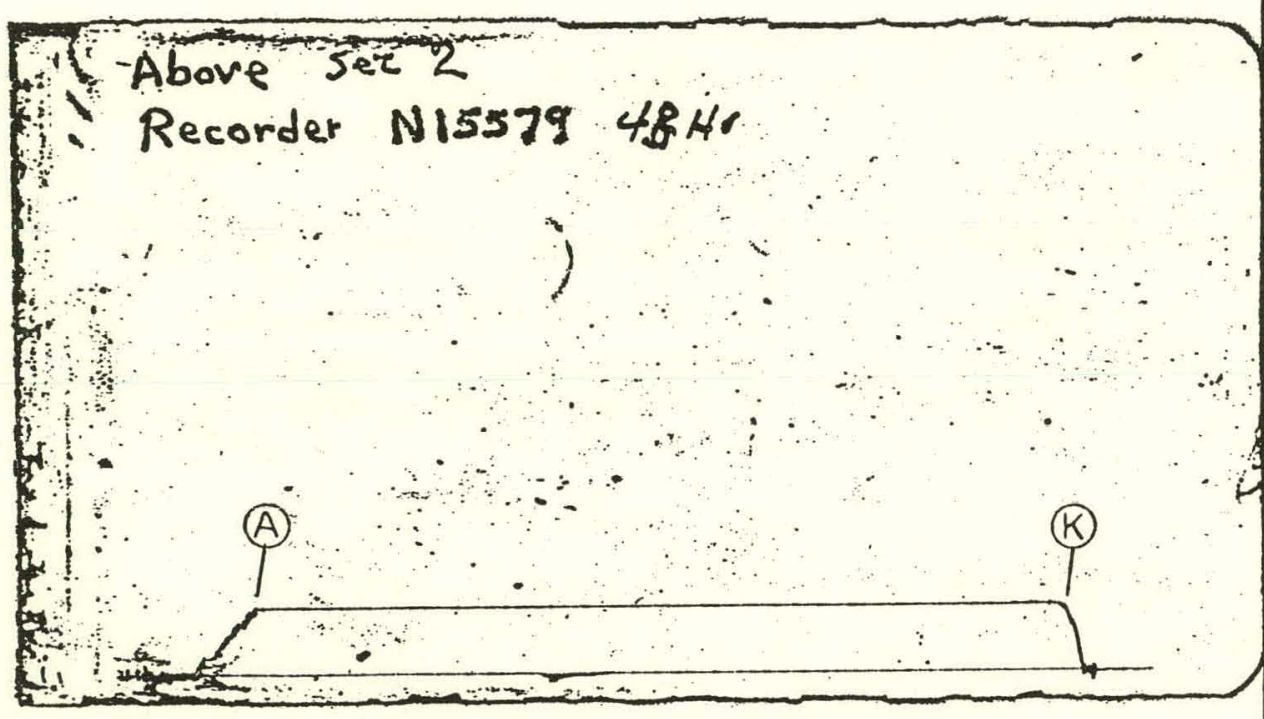

Pressure Below Bottom

Packer Bled To

Above Interval

PRD Make Kuster $\mathrm{K}-3$

No. 15579 Cap. $6200 @ 2683^{\prime}$

Press

static

\begin{tabular}{l|c} 
A & 686 \\
\hline
\end{tabular}

\begin{tabular}{ll|l} 
Initial Hydrostatic & A & 686 \\
\hline Final Hydrostatic & K. & 712
\end{tabular}

Initial Flow

Final Initial Flow

Initial Shut-in

Second Initial Flow

Second Final Flow

Second Shut-in

Third Initial Flow

Third Final Flow

Third Shut-in

Charts indicate clock stopped during test.

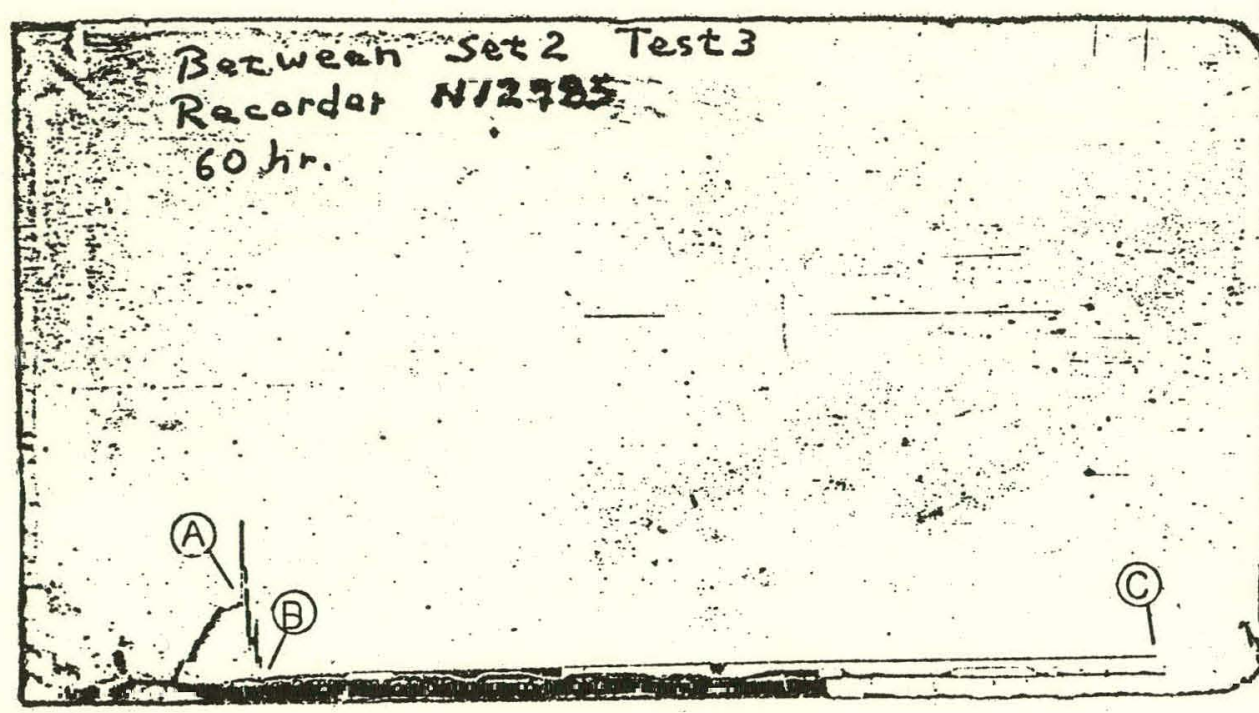

Between Interval

PRD Make Kuster K-3

No. 12985 Cap. $6100 @ 2712^{\prime}$

Press

Initial Hydrostatic

Final Hydrostatic

Initial Flow

Final Initial Flow

Initial Shut-in

Second Initial Flow

Second Final Flow

Second Shut-in

Third Initial Flow

Third Final Flow

Third Shut-in

\begin{tabular}{c|c}
\hline Corrected \\
\hline K & 729 \\
\hline$B$ & -- \\
\hline C & 24 \\
\hline$D$ & 170 \\
\hline$E$ & -- \\
\hline$F$ & -- \\
\hline$G$ & - \\
\hline$H$ & - \\
\hline I & -- \\
\hline$J$ & -- \\
\hline & \\
\hline
\end{tabular}

Pressure Below

Clock ran out 3107 minutes

into test. 


\section{LYNES, INC.}

Operator Arco Hanford Co.

Lease \& No. RSH 非1

DST No. 3

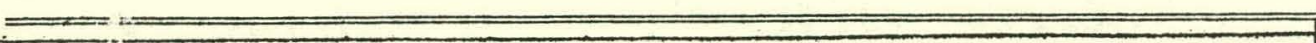

$\checkmark$

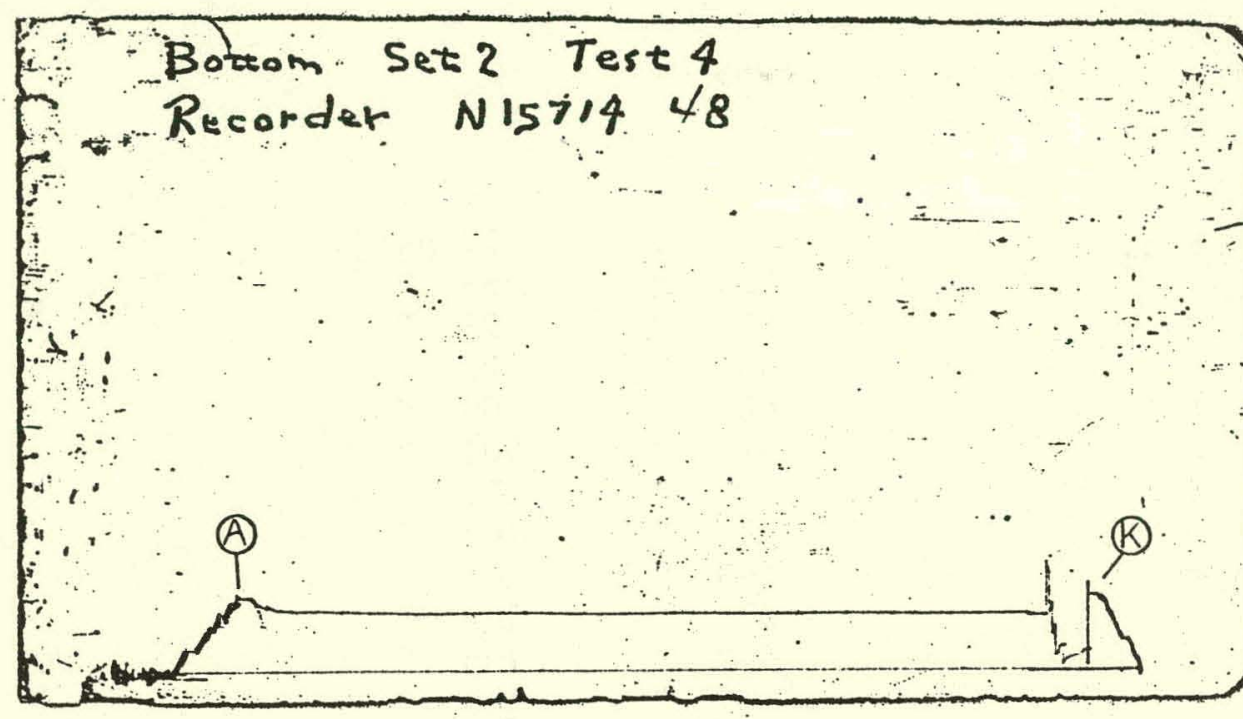

Below Interval

PRD Make Kuster K-3

No. $\frac{15714 \text { Cap. } 6000}{\text { Press }} @ \frac{2776^{1}}{\text { Corrected }}$

\begin{tabular}{ll|l} 
Initial Hydrostatic A & 750
\end{tabular}

\begin{tabular}{ll|l} 
Final Hydrostatic & K: & 747
\end{tabular}

Initial Flow

Final Initial Flow

Initial Shut-in

Second Initial Flow

Second Final Flow

Second Shut-in

Third Inilial Fluw

Third Final Flow

Third Shut-in

C

--

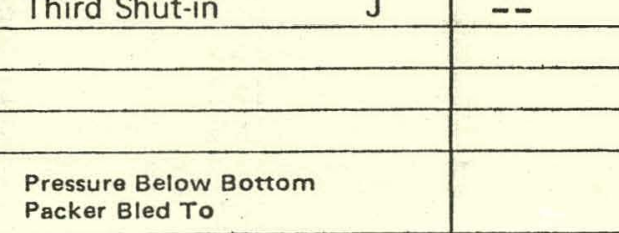

Charts indicate clock stopped during test.

PRD Make

\begin{tabular}{|ll|l}
\multicolumn{1}{c}{ No. Cap. } & \multicolumn{2}{c}{ Corrected } \\
\hline Initial Hydrostatic & A & \\
\hline Final Hydrostatic & K & \\
\hline Initial Flow & B & \\
\hline Final Initial Flow & C & \\
\hline Initial Shut-in & D & \\
\hline Second Initial Flow & E & \\
\hline Second Final Flow & F & \\
\hline Second Shut-in & G & \\
\hline Third Initial Flow & H & \\
\hline Third Final Flow & I & \\
\hline Third Shut-in & J & \\
\hline & & \\
\hline & & \\
\hline & & \\
\hline & \\
\hline
\end{tabular}




\section{LYNES, INC.}

Operator Arco Hanford Co. Lease \& No._RSH \#1 DST No.

Recorder No. 12985

\begin{tabular}{|c|c|c|c|}
\hline 0 & min. & 24 & psig \\
\hline 15 & " & 47 & " \\
\hline 30 & " & 52 & " \\
\hline 45 & " & 58 & " \\
\hline 60 & " & 60 & " \\
\hline 75 & " & 63 & 11 \\
\hline 90 & " & 65 & $"$ \\
\hline 105 & $"$ & 68 & $"$ \\
\hline 120 & " & 68 & $"$ \\
\hline 135 & " & 71 & $"$ \\
\hline 150 & " & 73 & $"$ \\
\hline 165 & $"$ & 73 & $"$ \\
\hline 180 & $"$ & 76 & $"$ \\
\hline 195 & $"$ & 76 & $"$ \\
\hline 210 & $"$ & 77 & $"$ \\
\hline 225 & " & 79 & 1 \\
\hline 240 & $"$ & 80 & $"$ \\
\hline 255 & " & 82 & ' \\
\hline 270 & " & 82 & , \\
\hline 285 & $"$ & 82 & 11 \\
\hline 300 & " & 84 & " \\
\hline 315 & $"$ & 86 & " \\
\hline 330 & $"$ & 87 & $"$ \\
\hline 345 & " & 88 & " \\
\hline 360 & " & 89 & $"$ \\
\hline 375 & $"$ & 89 & $"$ \\
\hline 390 & $"$ & 90 & $"$ \\
\hline 405 & $" 1$ & 90 & " \\
\hline 420 & 11 & 92 & " \\
\hline 435 & " & 93 & " \\
\hline 450 & $"$ & 93 & $"$ \\
\hline 465 & $"$ & 94 & $"$ \\
\hline 480 & $"$ & 94 & 11 \\
\hline 495 & $" 1$ & 95 & $"$ \\
\hline 510 & $"$ & 95 & " \\
\hline 525 & $"$ & 96 & $"$ \\
\hline
\end{tabular}

\begin{tabular}{|c|c|c|c|}
\hline 540 & $\min$. & 97 & psig. \\
\hline 555 & $"$ & 28 & " \\
\hline 570 & $"$ & 99 & $"$ \\
\hline 585 & " & 99 & " \\
\hline 600 & " & 100 & $"$ \\
\hline 615 & " & 101 & " \\
\hline 630 & $"$ & 101 & $"$ \\
\hline 645 & $"$ & 102 & " \\
\hline 660 & " & 102 & " \\
\hline 675 & " & 103 & " \\
\hline 690 & " & 103 & " \\
\hline 705 & " & 104 & $"$ \\
\hline 720 & " & 104 & " \\
\hline 735 & " & 105 & $"$ \\
\hline 750 & " & 105 & $"$ \\
\hline 765 & " & 105 & " \\
\hline 780 & $"$ & 106 & $"$ \\
\hline 795 & $"$ & 107 & " \\
\hline 810 & $"$ & 107 & " \\
\hline 825 & $"$ & 108 & $"$ \\
\hline 840 & $"$ & 109 & $"$ \\
\hline 855 & " & 110 & $"$ \\
\hline 870 & $"$ & 111 & " \\
\hline 885 & $"$ & 111 & $"$ \\
\hline 900 & $"$ & 112 & $"$ \\
\hline 915 & " & 113 & " \\
\hline 930 & $"$ & 113 & $"$ \\
\hline 945 & 11 & 113 & $"$ \\
\hline 960 & $"$ & 114 & " \\
\hline 975 & " & 114 & " \\
\hline 990 & $"$ & 115 & " \\
\hline 1005 & $"$ & 115 & " \\
\hline 1020 & $"$ & 116 & " \\
\hline 1035 & $"$ & 116 & " \\
\hline 1050 & $"$ & 117 & $"$ \\
\hline 1065 & " & 118 & " \\
\hline
\end{tabular}




\section{LYNES, INC.}

Operator Arco Hanford Co. Lease \& No._RSH \# 1

DST No. 3

Recorder No. 12985

\begin{tabular}{|c|c|c|c|c|c|c|c|}
\hline 1080 & $\min$. & 119 & psig. & 1620 & $\min$. & 136 & psig. \\
\hline 1095 & $"$ & 119 & 11 & 1635 & $"$ & 137 & $"$ \\
\hline 1110 & " & 119. & 11 & 1650 & " & 137 & " \\
\hline 1125 & 11 & 120 & " & 1665 & $"$ & 137 & 11 \\
\hline 1140 & $"$ & 120 & " & 1680 & $"$ & 138 & " \\
\hline 1155 & $"$ & 121 & " & 1695 & " & 138 & 11 \\
\hline 1170 & $"$ & 121 & 11 & 1710 & " & 138 & 11 \\
\hline 1185 & $"$ & 121 & " & 1725 & $"$ & 138 & 11 \\
\hline 1200 & $"$ & 122 & 11 & 1740 & $"$ & 139 & 11 \\
\hline 1215 & " & 122 & $"$ & 1755 & " & 139 & " \\
\hline 1230 & " & 123 & " & 1770 & $"$ & 139 & " \\
\hline 1245 & $"$ & 123 & $"$ & 1785 & " & 139 & $"$ \\
\hline 1260 & " & 124 & " & 1800 & $"$ & 140 & " \\
\hline 1275 & $"$ & 124 & " & 1815 & $"$ & 140 & $"$ \\
\hline 1290 & $"$ & 125 & $"$ & 1830 & $"$ & 140 & 11 \\
\hline 1305 & $"$ & 126 & " & 1845 & " & 140 & " \\
\hline 1320 & " & 126 & $"$ & 1860 & " & 141 & " \\
\hline 1335 & " & 127 & " & 1875 & " & 141 & $"$ \\
\hline 1350 & $"$ & 127 & " & 1890 & " & 141 & " \\
\hline 1365 & $"$ & 128 & " & 1905 & $"$ & 142 & $"$ \\
\hline 1380 & $"$ & 128 & " & 1920 & " & 142 & $"$ \\
\hline 1395 & $"$ & 129 & " & 1935 & " & 142 & " \\
\hline 1410 & $"$ & 129 & " & 1950 & " & 142 & $"$ \\
\hline 1425 & $"$ & 130 & " & 1965 & $"$ & 143 & " \\
\hline 1440 & $"$ & 131 & " & 1980 & " & 143 & " \\
\hline 1455 & " & 131 & " & 1995 & " & 143 & " \\
\hline 1470 & $"$ & 132 & " & 2010 & " & 144 & " \\
\hline 1485 & " & 132 & " & 2025 & " & 144 & " \\
\hline 1500 & " & 133 & " & 2040 & "I" & 144 & " \\
\hline 1515 & " & 133 & " & 2055 & " & 145 & " \\
\hline 1530 & $"$ & 134 & " & 2070 & " & 145 & " \\
\hline 1545 & " & 135 & " & 2085 & " & 145 & " \\
\hline 1560 & " & 135 & $"$ & 2100 & " & 146 & " \\
\hline 1575 & " & 135 & " & 2115 & " & 146 & " \\
\hline 1590 & " & 136 & " & 2130 & " & 146 & " \\
\hline 1605 & $"$ & 136 & $"$ & 2145 & $"$ & 147 & " \\
\hline
\end{tabular}




\section{LYNES, INC.}

Operator Arco Hanford Co. Lease \& No._RSH \# 1 DST No. 3

Recorder No. 12985

\begin{tabular}{|c|c|c|c|c|c|c|c|}
\hline $\begin{array}{l}2160 \\
2175\end{array}$ & $\min _{11}$ & $\begin{array}{l}147 \\
147\end{array}$ & ${ }_{\text {" }} \mathrm{ig}$. & 2655 & min. & 158 & $\operatorname{psig}$ \\
\hline $\begin{array}{l}2175 \\
2190\end{array}$ & $"$ & $\begin{array}{l}147 \\
148\end{array}$ & " & $\begin{array}{l}2670 \\
2685\end{array}$ & " & $\begin{array}{l}158 \\
159\end{array}$ & " \\
\hline 2205 & $"$ & 148 & $"$ & 2700 & $1 "$ & 159 & $"$ \\
\hline 2220 & $"$ & 148 & $"$ & 2715 & $"$ & 159 & $"$ \\
\hline 2235 & " & 148 & $"$ & 2730 & " & 160 & " \\
\hline 2250 & $"$ & 149 & " & 2745 & 11 & 160 & $"$ \\
\hline 2265 & $"$ & 149 & $"$ & 2760 & 11 & 161 & $"$ \\
\hline 2280 & $"$ & 149 & $"$ & 2775 & $"$ & 161 & $"$ \\
\hline 2295 & $"$ & 150 & $"$ & 2790 & $"$ & 162 & " \\
\hline 2310 & $"$ & 150 & " & 2805 & " & 162 & $"$ \\
\hline 2325 & $"$ & 150 & $"$ & 2820 & $"$ & 163 & $"$ \\
\hline $2340^{\circ}$ & " & 151 & $"$ & 2835 & $"$ & 163 & $"$ \\
\hline 2355 & $"$ & 151 & $"$ & 2850 & $"$ & 163 & 11 \\
\hline 2370 & $"$ & 151 & $"$ & 2865 & $"$ & 164 & $"$ \\
\hline 2385 & $"$ & 152 & $"$ & 2880 & $"$ & 164 & $"$ \\
\hline 2400 & $"$ & 152 & $"$ & 2895 & $"$ & 164 & $"$ \\
\hline 2415 & $"$ & 152 & $"$ & 2910 & $"$ & 165 & 11 \\
\hline 2430 & $"$ & 153 & $"$ & 2925 & $"$ & 165 & $"$ \\
\hline 2445 & $"$ & 153 & $"$ & 2940 & $"$ & 166 & " \\
\hline 2460 & " & 153 & $"$ & 2955 & $"$ & 166 & " \\
\hline 2475 & $"$ & 154 & $"$ & 2970 & $"$ & 167 & " \\
\hline 2490 & " & 154 & $"$ & 2985 & $"$ & 167 & " \\
\hline 2505 & " & 154 & $"$ & 3000 & " & 167 & $"$ \\
\hline 2520 & $"$ & 155 & $"$ & 3015 & " & 168 & " \\
\hline 2535 & " & 155 & $"$ & 3030 & " & 168 & " \\
\hline 2550 & $"$ & 155 & $"$ & 3045 & " & 169 & " \\
\hline 2565 & $"$ & 156 & $"$ & 3060 & " & 169 & " \\
\hline 2580 & " & 156 & $"$ & 3075 & $"$ & 169 & $"$ \\
\hline 2595 & $"$ & 157 & $"$ & 3090 & " & 170 & $"$ \\
\hline 2610 & " & 157 & " & 3105 & $"$ & 170 & $"$ \\
\hline 2625 & $"$ & 157 & $"$ & 3107 & " & 170 & $"$ \\
\hline 2640 & $"$ & 158 & $"$ & & & & \\
\hline
\end{tabular}




\section{TEST 1-3}

Water Pressures Between Packers*

$\underline{\text { Time (Min) }}$

0

60

180

270

1140

1560

3060 $\underline{\text { PSIG }}$

14.7

115

122

125

135

150

160

*Electric tape measurement. 
TEST 1-4 
Phone

522-1206 Area 303

\section{LYNES, INC.}

\begin{tabular}{|c|c|c|}
\hline Spot & -- & Csg. Size \& Grade \\
\hline Sec. & -- & Tubing Size $\quad 27 / 8^{\prime \prime} 6.5$ 非 \\
\hline Twp._ & -- & $2770-2860^{\prime}$ \\
\hline Rng. & -- & On Location@_ \\
\hline Field & Rattle Snake Hill & Off Location@ \\
\hline County_ & Benton & Lynes Rep. \\
\hline State & Washington & Well Owners Rep. \\
\hline
\end{tabular}

Box 712 Sterling, Colo.

Tool Description_ Treating \& Testing Tool

Packer size $73 / 8^{\prime \prime} \times 66^{\prime \prime}$

PO\# WTC-SBB-39166

Summary: $\quad$ Test 非

$5-2-77$

$9: 25$ AM.

Moved tool to below position, began swabbing. Swabbed down at 10:07 AM. Let set open for 60 minutes. Made swab run to check for recovery. Recovered 50 gallons of water. Filled tubing, released packers.

Flowing pressures in 15 minute increments on following pages. 


\section{LYNES, INC.}

Operator Arco Hanford Co.

Lease \& No. RSH \#1

DST No. 4

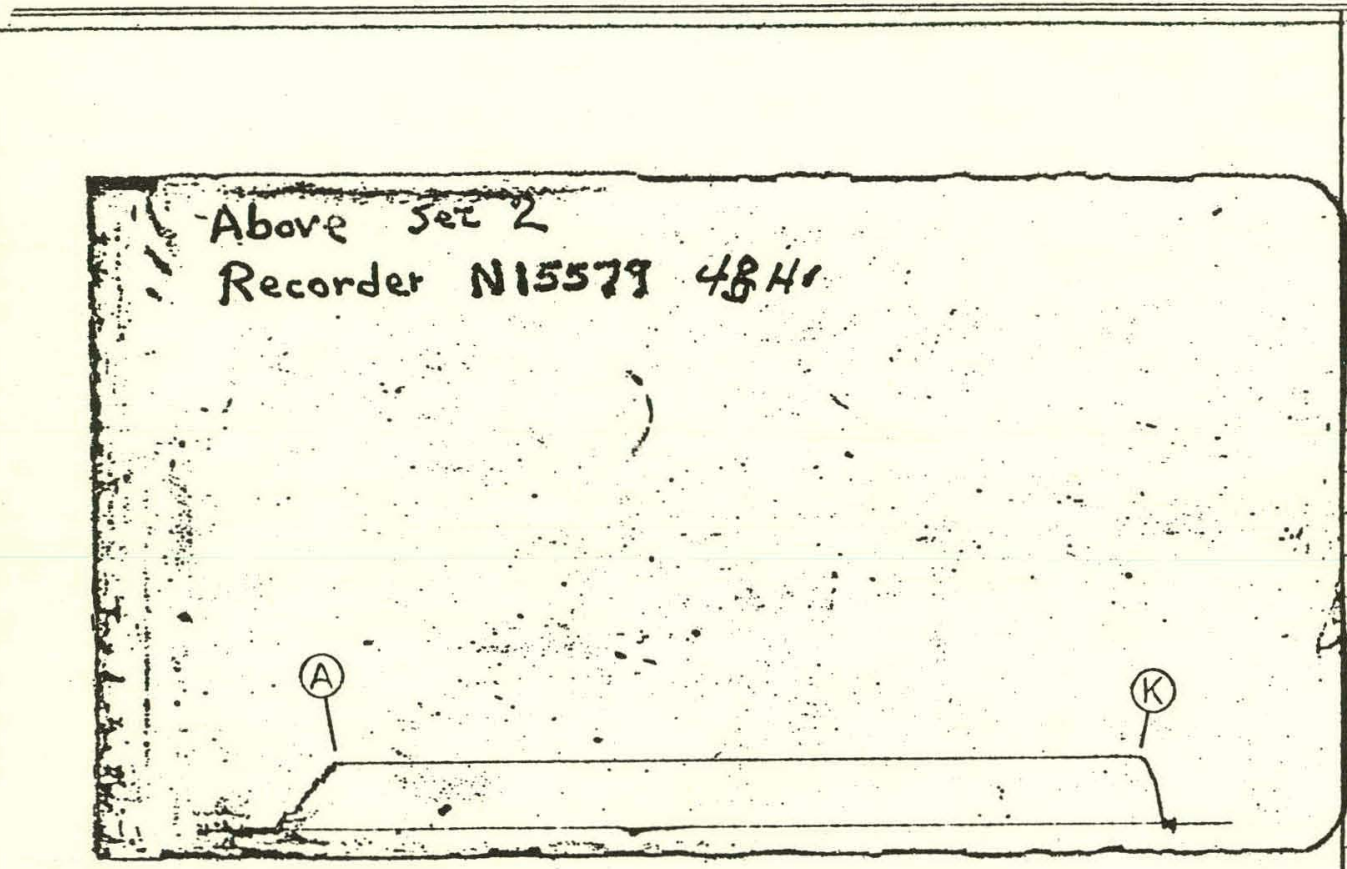

Pressure Below Bottom

Above Interval

PRD Make Kuster $\mathrm{K}-3$

No. 15579 Cap. 6200 @ $2683^{\prime}$

Press

\begin{tabular}{|l|l|}
\hline Initial Hydrostatic A & 686 \\
\hline
\end{tabular}

\begin{tabular}{ll|l}
\hline Final Hydrostatic & $K$ & 712 \\
\hline
\end{tabular}

Initial Flow

Final Initial Flow

Initial Shut-in

Second Initial Flow

Second Final Flow

Second Shut-in

Third Initial Flow

Third Final Flow

Third Shut-in

Charts indicate clock

stopped during test.

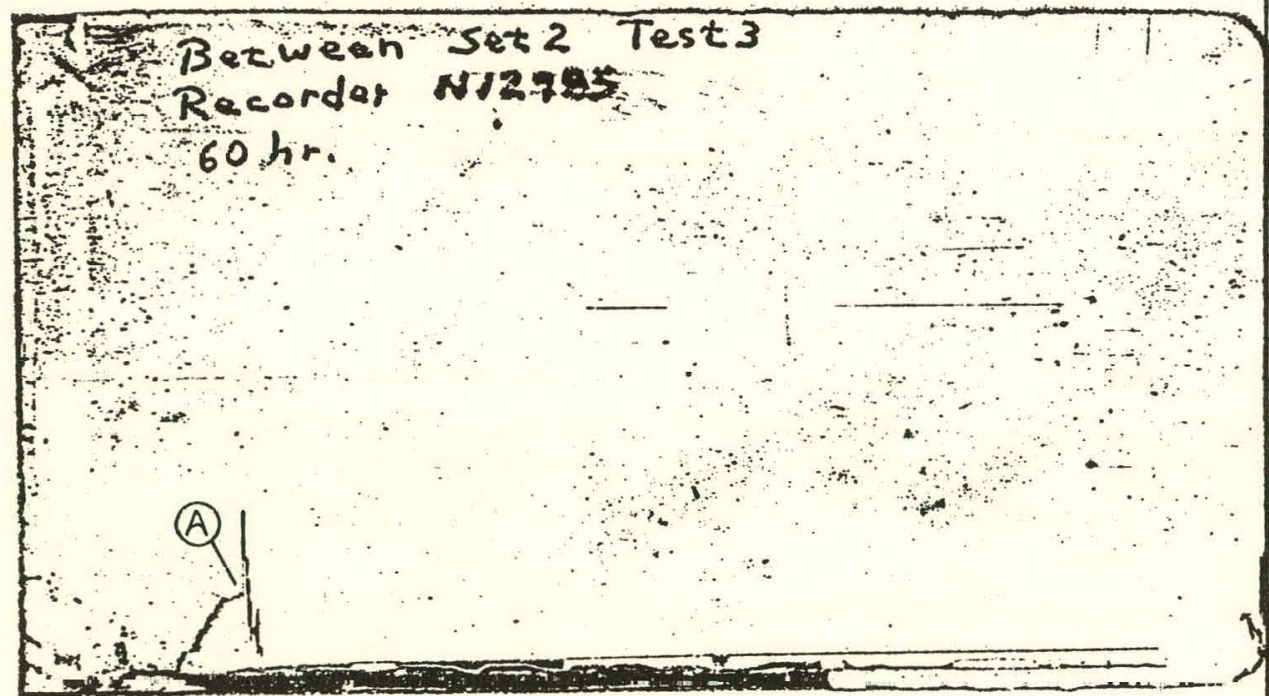

Between Interval

PRD Make Kuster K-3

No. 12985 Cap.6100@2712 Press Corrected

\begin{tabular}{ll|l} 
Initial Hydrostatic A & $\mathbf{7 2 9}$
\end{tabular}

Final Hydrostatic

Initial Flow

Final Initial Flow

Initial Shut-in

Second Initial Flow

Second Final Flow

Second Shut-in

Third Initial Flow

Third Final Flow

Third Shut in

\begin{tabular}{|l|l}
\hline Third Shut in & J \\
\hline & \\
\hline & \\
\hline $\begin{array}{l}\text { Pressure Below Bottom } \\
\text { Packer Bled To }\end{array}$ & \\
\hline
\end{tabular}




\section{LYNES, INC.}

Operator Arco Hanford Co.

Lease \& No. RSH \# 1

DST No.

4

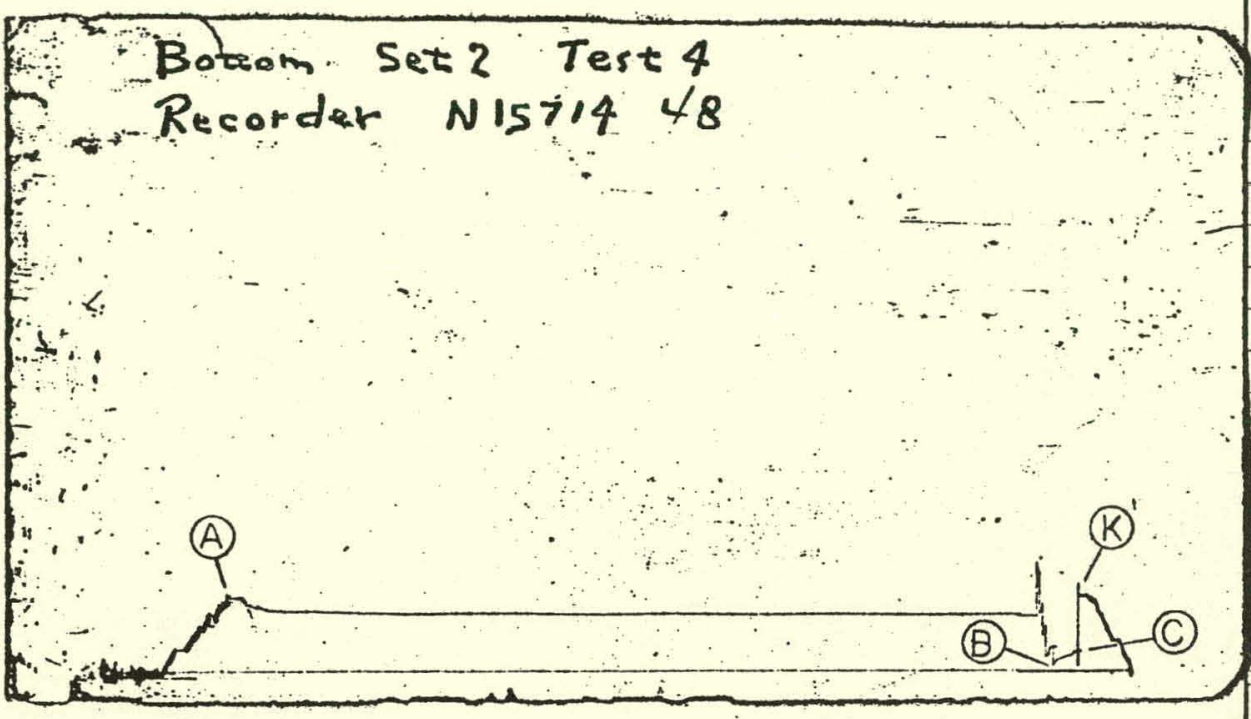

Below Interval

PRD Make Kuster $\mathrm{K}-3$

No. 15714 Cap. $6000 @ 2776^{\prime}$

\begin{tabular}{ll|l} 
Initial Hydrostatic & A & $\mathbf{7 5 0}$
\end{tabular}

\begin{tabular}{ll|l}
\hline Final Hydrostatic & K. & 747
\end{tabular}

Initial Flow

Final Initial Flow

Initial Shut-in

Second Initial Flow

Second Final Flow

Second Shut-in

Third Initial Flow

Third Final Flow

Third Shut-in

\begin{tabular}{l|r} 
B & 48 \\
\hline C & 162
\end{tabular}

\begin{tabular}{l|l}
$D$ & -- \\
\hline$E$ & --
\end{tabular}

PRD Make

No

Pressure Below Bottom

Packer Bled To

$\mathrm{F}$

G

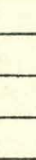

$--$




\section{LYNES, INC.}

Operator Arco Hanford Co. Lease \& No. RSH 非 1 DST No. 4

Recorder No. 15714

$\begin{array}{llll}0 & \text { min. } & 48 & \text { psig. } \\ 15 & \text { " } & 114 & \text { " } \\ 30 & & 131 & \text { " } \\ 45 & \text { " } & 146 & \text { " } \\ 60 & & 162 & \end{array}$




\section{TEST 1-4}

Water Pressures Below Packers*

$\underline{T i m e(M i n)}$

$\underline{P S I G}$

0

80

51

100

60

135

75

165

90

195

105

235

*Electric tape measurement. 
TEST 1-5 


Spot $\frac{--}{--}$
Sec.
Twp.
Rng. $\frac{--}{--}$
Field Rattle Snake Hill
County Benton
State Washington

$\begin{array}{ll}\text { Csg. Size \& Grade } & 133 / 8^{\prime \prime} \\ \text { Tubing Size } & 27 / 8^{\prime \prime} 6.5 \# \\ \text { Tool Depth } & 2610-2690^{\prime} \\ \text { On Location @ } & -- \\ \text { Off Location @ } & -- \\ \text { Lynes Rep. } & \text { Stan Anama } \\ \text { Well Owners Rep. } & \text { Paul Eddy }\end{array}$

Tool Description

Treating \& Testing Tool

Packer size $73 / 8^{\prime \prime} \times 66^{\prime \prime}$

PO非 WTC-SBB-39166

Summary:

Test 非

5-4-77

$2: 45$ PM.

Filled tubing. Inflated packers to 600 psig. surface pressure. 4:00 PM.

Moved tool to between position, began swabbing. Swabbed down at 4:52 PM. Let set for 1075 minutes.

$5-4-77$ $8: 00$ AM.

Ran swab to check for recovery. No recovery. Filled tubing to equalize between packers, unable to work weight down to tools. Swabbed tubing, then refilled tubing, unable to get movement. Swabbed down and refilled tubing again. Released packers and came out of hole.

Flowing pressures in 15 minute increments on following pages. 


\section{LYNES, INC.}

Operator Arco Hanford Co.

Lease \& No.

RSH 非 1

DST No. 5

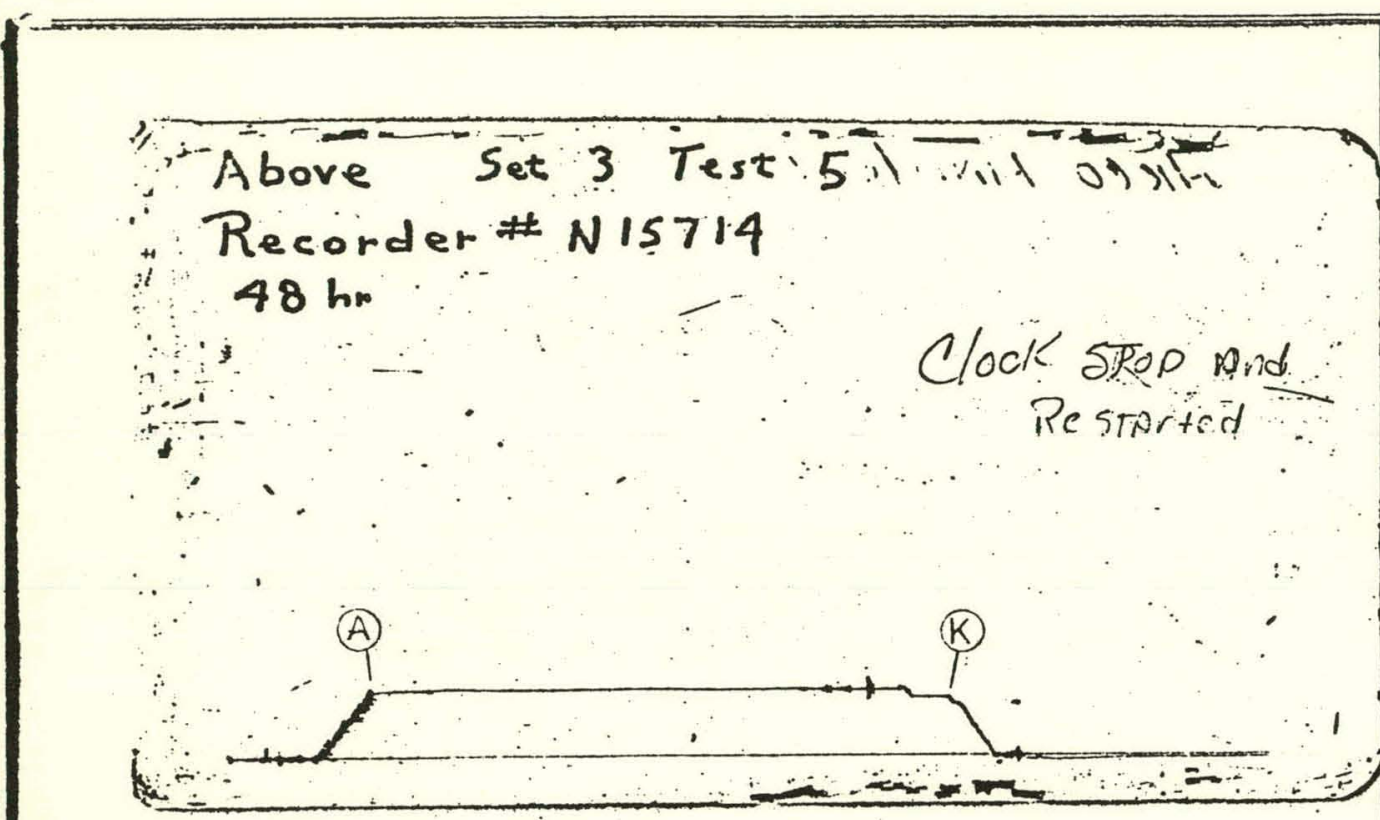

Pressure Below Bottom

Packer Bled To

Above Interval

PRD Make Kuster $\mathrm{K}-3$

No. 15714 Cap. 6000 @ 2593' Press

Initial Hydrostatic

Final Hydrostatic

Initial Flow

Final Initial Flow

Initial Shut-in

Second Initial Flow

Second Final Flow

Second Shut-in

Third Initial Flow

Third Final Flow

Third Shut-in
Corrected

\begin{tabular}{l|l} 
A & 644 \\
\hline
\end{tabular}

\begin{tabular}{l|l} 
K. & 672 \\
\hline B & -- \\
\hline
\end{tabular}

\begin{tabular}{c|c} 
B & -- \\
C & -- \\
\hline$D$ & --
\end{tabular}

\begin{tabular}{l|c}
$\mathrm{D}$ & - \\
\hline $\mathrm{F}$ & --
\end{tabular}

\begin{tabular}{l|l} 
G & --
\end{tabular}

\begin{tabular}{c|c}
$\mathrm{G}$ & - \\
\hline$H$ & - \\
\hline $\mathrm{I}$ & -- \\
\hline $\mathrm{J}$ & - \\
\hline & \\
\hline & \\
\hline
\end{tabular}

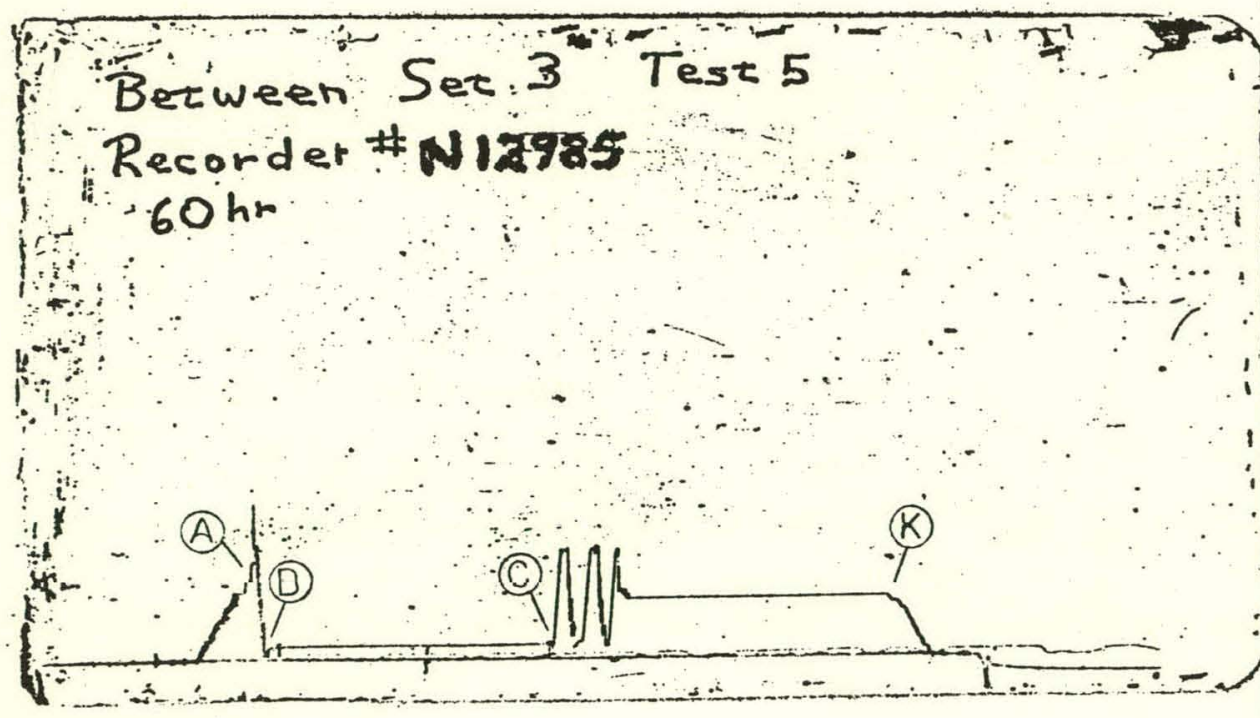

Between Interval

PRD Make Kuster K-3

No. 12985 Cap. $6100 @ 2622^{\prime}$

Press Corrected

\begin{tabular}{|l|l|l}
\hline Initial Hydrostatic & A & 668
\end{tabular}

\begin{tabular}{ll|l}
\hline Final Hydrostatic & $K$ & 666
\end{tabular}

Initial Flow

\begin{tabular}{ll|r}
\hline Final Initial Flow & C & 152
\end{tabular}

Initial Shut-in

Second Initial Flow

Second Final Flow

Second Shut-in

Third Initial Flow

Third Final Flow

Third Shut-in

E




\section{LYNES, INC.}

Operator Arco Hanford Co.

Lease \& No. RSH \#1

DST No. 5

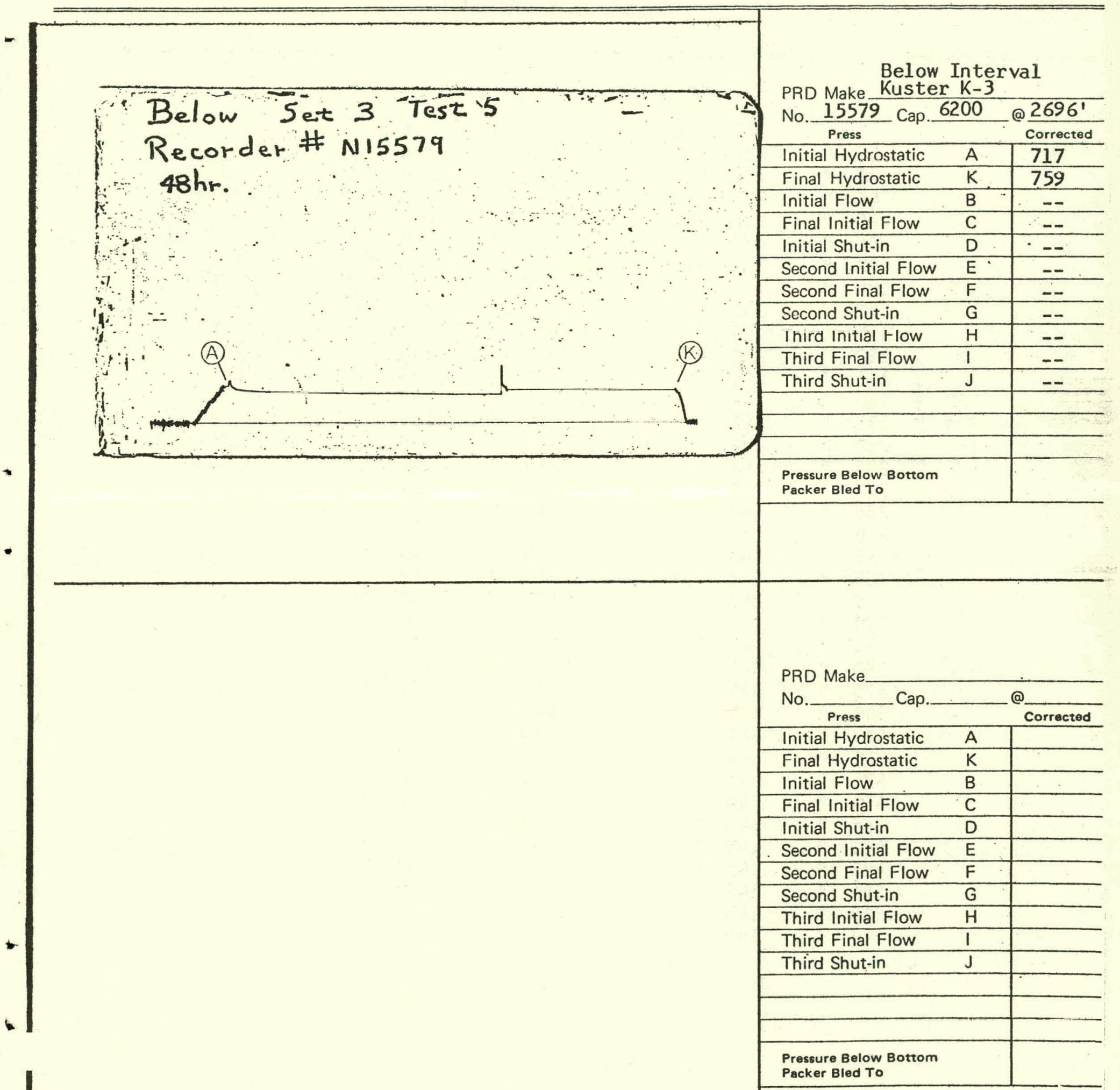




\section{LYNES, INC.}

Operator_Arco Hanford Co. Lease \& No.

RSH 非 DST No 5

\section{Recorder No. 12985}

\begin{tabular}{|c|c|c|c|c|c|c|c|}
\hline & in. & & ssig. & 555 & in. & 146 & sig. \\
\hline 15 & " & 132 & " & 570 & " & 146 & \\
\hline 30 & " & 134 & " & 585 & " & 146 & \\
\hline 45 & " & 135 & " & 600 & " & 146 & $"$ \\
\hline 60 & " & 136 & " & 615 & " & 146 & " \\
\hline 75 & " & 137 & " & 630 & " & 147 & $"$ \\
\hline 90 & " & 138 & " & 645 & " & 147 & " \\
\hline 105 & " & 139 & " & 660 & " & 147 & " \\
\hline 120 & " & 139 & " & 675 & " & 148 & " \\
\hline 135 & " & 140 & " & 690 & " & 148 & " \\
\hline 150 & " & 140 & " & 705 & " & 148 & " \\
\hline 165 & $"$ & 141 & " & 720 & " & 148 & " \\
\hline 180 & " & 141 & " & 735 & " & 149 & " \\
\hline 195 & $"$ & 141 & " & 750 & " & 149 & " \\
\hline 210 & " & 142 & " & 765 & " & 149 & " \\
\hline 225 & " & 142 & " & 780 & " & 149 & " \\
\hline 240 & " & 142 & " & 795 & " & 149 & $"$ \\
\hline 255 & " & 142 & " & 810 & " & 149 & " \\
\hline 270 & " & 142 & " & 825 & " & 149 & " \\
\hline 285 & " & 143 & $"$ & 840 & $"$ & 149 & $"$ \\
\hline 300 & " & 143 & $"$ & 855 & " & 149 & " \\
\hline 315 & " & 143 & " & 870 & " & 149 & " \\
\hline 330 & " & 143 & " & 885 & " & 130 & $"$ \\
\hline 345 & " & 143 & " & 900 & " & 150 & " \\
\hline 360 & " & 144 & " & 915 & " & 150 & " \\
\hline 375 & " & 144 & " & 930 & " & 151 & " \\
\hline 390 & " & 144 & " & 945 & " & 151 & " \\
\hline 405 & " & 144 & " & 960 & " & 152 & " \\
\hline 420 & " & 144 & " & 975 & " & 152 & " \\
\hline 435 & " & 144 & " & 990 & " & 152 & " \\
\hline 450 & " & 144 & $"$ & 1005 & $"$ & 152 & " \\
\hline 465 & " & 145 & " & 1020 & " & 152 & $"$ \\
\hline 480 & " & 145 & " & 1035 & " & 152 & " \\
\hline 495 & " & 145 & $"$ & 1050 & " & 152 & " \\
\hline 510 & " & 145 & " & 1065 & " & 152 & " \\
\hline 525 & " & 145 & " & 1075 & " & 152 & " \\
\hline 540 & " & 145 & " & & & & \\
\hline
\end{tabular}


TEST 1-6 


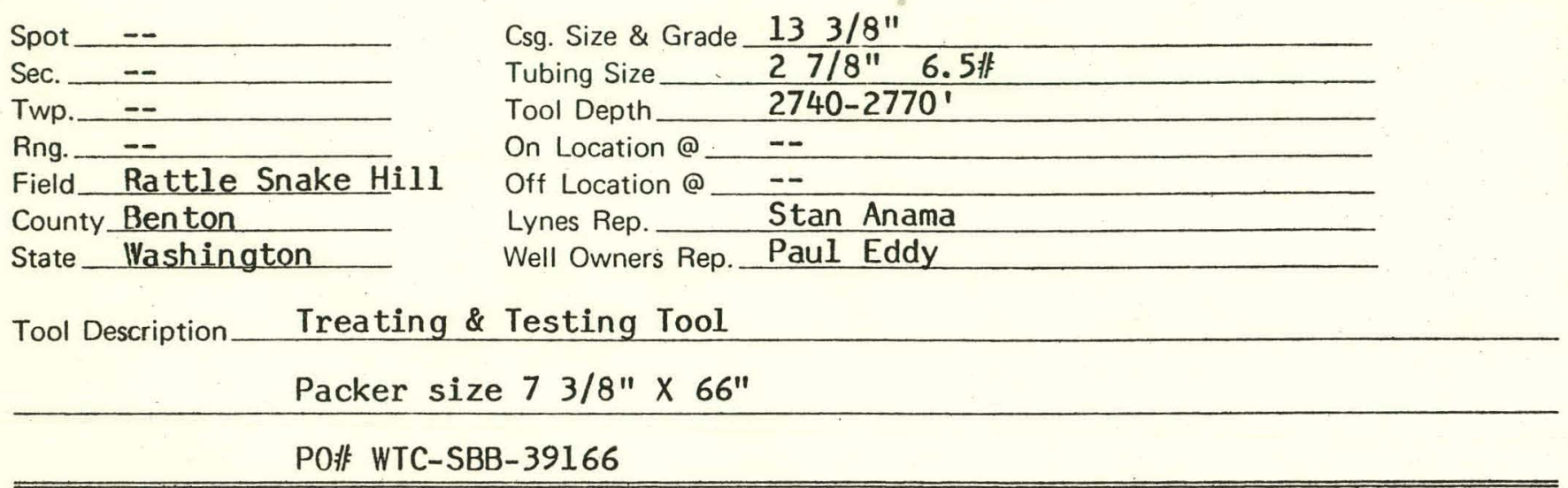

Summary:

Test \#6

5-5-77

3:30 PM. Start in hole with tools.

7:30 PM. Tools in place. Let set overnight.

$5-6-77$

8:00 AM. Filled tubing and inflated packers with 500 psig. surface pressure.

9:30 AM. Moved tool to between position. Applied 600 psig. surface pressure with argon cylinders, bled pressure to $450 \mathrm{psig.}$ Re-applied 600 psig., bled pressure to 500 psig. Held sUU psig. over weekend.

$5-9-77$

8:00 AM. Pressure @ 315 psig. Bled off pressure and released packers. Flowing pressures in 15 minute increments on following pages. 
LYNES, INC.

- Operator Arco Hanford Co.

Lease \& No. RSH 非1

DST No. 6
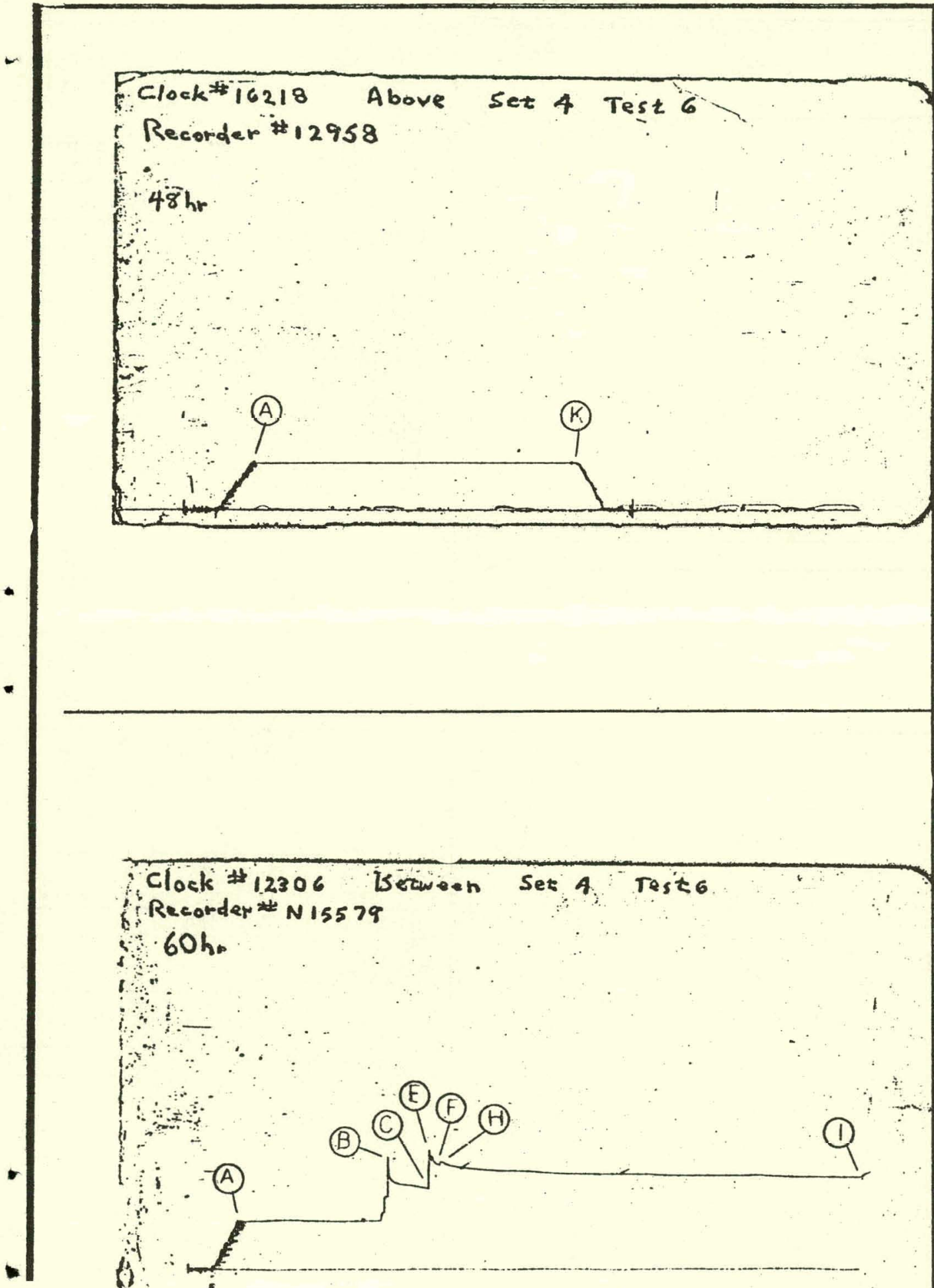

Above Interval

PRD Make Kuster K-3

No. 12985 Cap. $6100 @ 2723$

\begin{tabular}{ll|l} 
Initial Hydrostatic & A & 714
\end{tabular}

\begin{tabular}{ll|l} 
Final Hydrostatic & K. & 714
\end{tabular}

Initial Flow

Final Initial Flow

Initial Shut-in

Second Initial Flow

Second Final Flow

Second Shut-in

Third Initial Flow

Third Final Flow

Third Shut-in

\begin{tabular}{l|c} 
B & -- \\
\hline C & --
\end{tabular}

Pressure Below Bottom

Packer Bled To

D $\quad--$

E

F

$\mathrm{H} \quad--$

J

Between Interval

PRD Make Kuster K-3

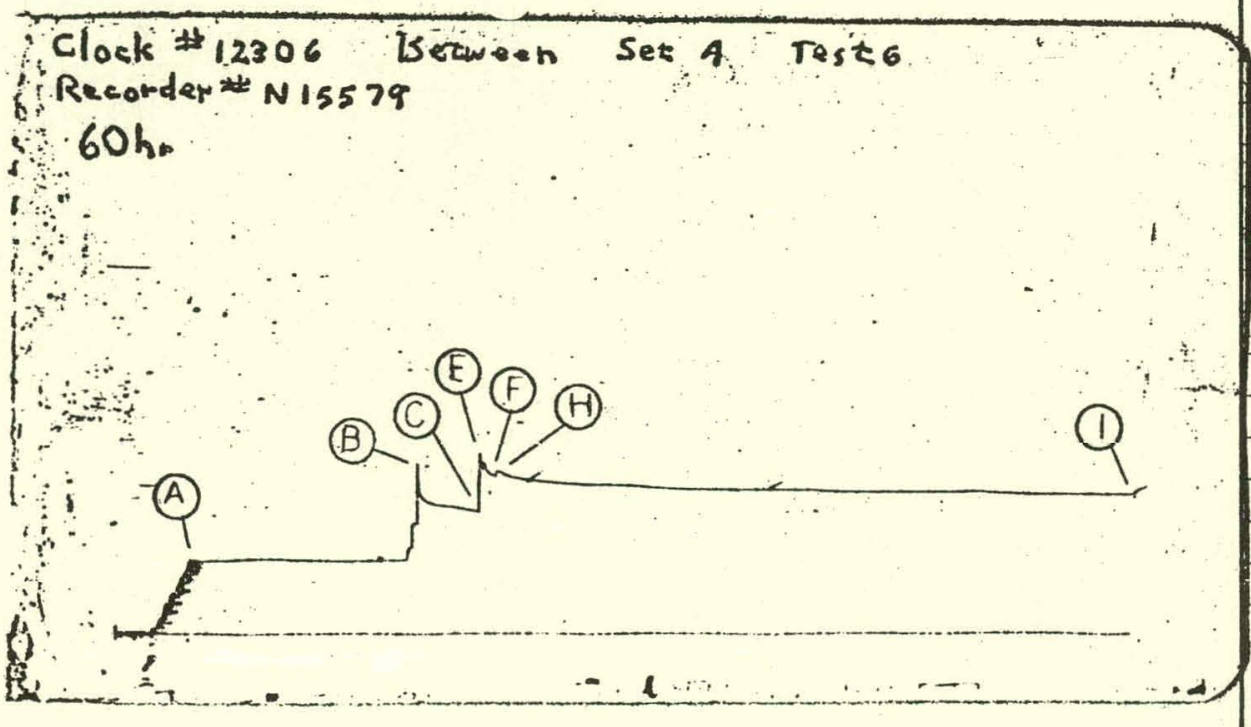

No. $\frac{15579}{\text { Press }}$ Cap. $6200 @ \frac{2752^{\prime}}{\text { Corrected }}$

\begin{tabular}{|ll|l}
\hline Initial Hydrostatic & A & 743
\end{tabular}

Final Hydrostatic $\mathrm{K}$--

\begin{tabular}{ll|l} 
Initial Flow & B & 1733
\end{tabular}

Final Initial Flow C $\quad 1251$

Initial Shut-in

Second Initial Flow

D $\quad--$

Second Final Flow

Second Shut-in

Third Initial Flow

Third Final Flow

Third Shut-in

F $: 17510$




\section{LYNES, INC.}

Operator Arco Hanford Co.

Lease \& No._ RSH 非I

DST No. 6

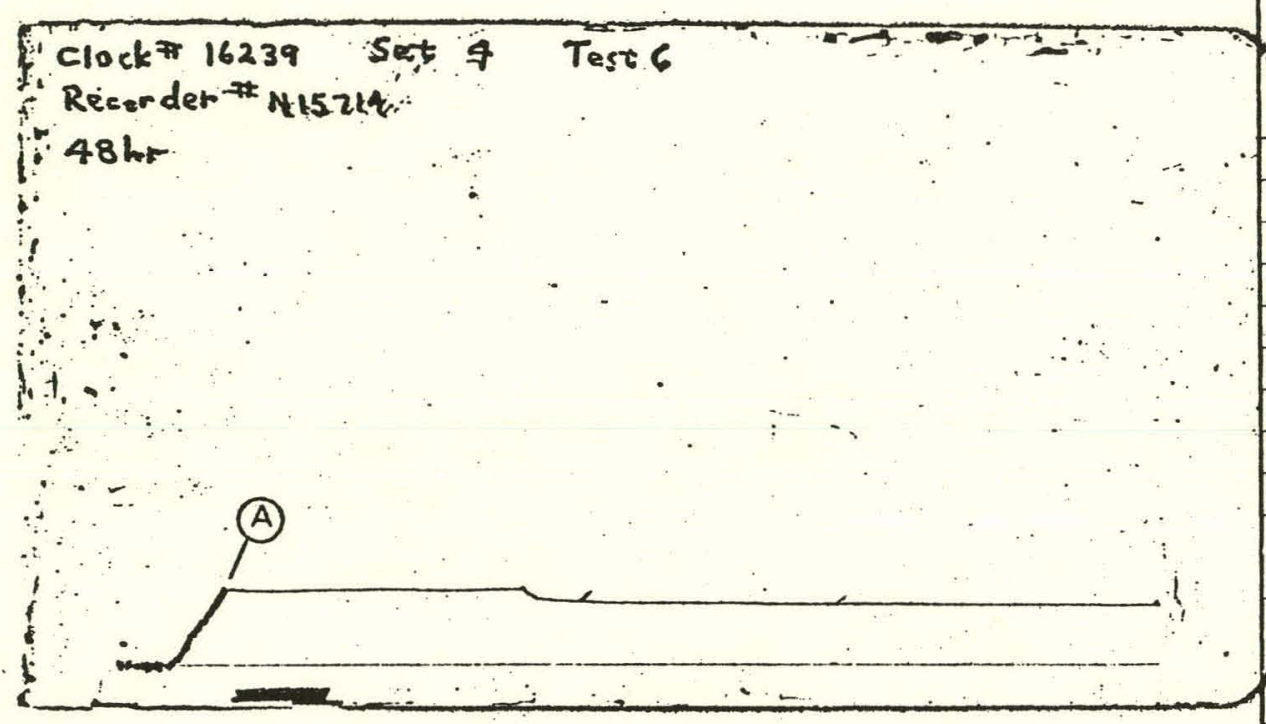

Below Interval

PRD Make Kuster K-3

No. $\frac{15714}{\text { Press }}$ Cap. $6000 @ \frac{2777^{\prime}}{\text { Corrected }}$

\begin{tabular}{l} 
In \\
\hline F \\
\hline Inita \\
\hline I \\
\hline S \\
\hline S \\
\hline Seco \\
\hline$T$ \\
\hline$T$ \\
\hline$T$ \\
\hline
\end{tabular}

Pressure Below Bottom

Packer Bled To

PRD Make

\begin{tabular}{|c|c|c|}
\hline \multirow{2}{*}{\multicolumn{3}{|c|}{ No.__ Cap.____ @__ }} \\
\hline & & \\
\hline Initial Hydrostatic & A & \\
\hline Final Hydrostatic & $\mathrm{K}$ & \\
\hline Initial Flow & B & \\
\hline Final Initial Flow & C & \\
\hline Initial Shut-in & D & \\
\hline Second Initial Flnw & $E$ & \\
\hline Second Final Flow & $\mathrm{F}$ & \\
\hline Second Shut-in & $\mathrm{G}$ & \\
\hline Third Initial Flow & $\mathrm{H}$ & \\
\hline Third Final Flow & 1 & \\
\hline Third Shut-in & $\mathrm{J}$ & \\
\hline$\therefore$ & & \\
\hline $\begin{array}{l}\text { Pressure Below Bottom } \\
\text { Packer Bled To }\end{array}$ & & \\
\hline
\end{tabular}




\section{LYNES, INC.}

Operator Arco Hanford Co. Lease \& No.

RSH 非 DST No

6

ecorder No. 15579

Initial Flow

\begin{tabular}{|c|c|c|c|}
\hline 0 & nin. & 1733 & psig \\
\hline 15 & $"$ & 1387 & \\
\hline 30 & " & 1353 & " \\
\hline 45 & $"$ & 1335 & $"$ \\
\hline 60 & $"$ & 1325 & $"$ \\
\hline 75 & " & 1312 & $"$ \\
\hline 90 & $"$ & 1306 & $"$ \\
\hline 105 & " & 1301 & $"$ \\
\hline 120 & 11 & 1296 & 'I \\
\hline 135 & $"$ & 1293 & " \\
\hline 150 & " & 1283 & " \\
\hline 165 & " & 1277 & 11. \\
\hline 180 & " & 1270 & $"$ \\
\hline 195 & $"$ & 1264 & $"$ \\
\hline 210 & $"$ & 1257 & "i \\
\hline 225 & " & 1251 & " \\
\hline
\end{tabular}

Second Flow

0 min. 1751 psig.

15 ". 1673 "

30 " $1641 "$

45 ". $1620 "$

$55 " 1610 "$ 
DST No. 6

Recorder No. 15579

Final Flow

\begin{tabular}{|c|c|c|c|c|c|c|c|c|c|c|c|c|c|c|}
\hline $\begin{array}{l}0 \text { min. } \\
15\end{array}$ & $\begin{array}{l}1660 \\
1641\end{array}$ & psig. & $\begin{array}{l}750 \\
765\end{array}$ & $\min _{1}$ & $\begin{array}{l}1480 \\
1480\end{array}$ & psig. & $\begin{array}{l}1500 \\
1515\end{array}$ & $\operatorname{nin}^{\prime \prime}$ & $\begin{array}{l}1450 \\
1450\end{array}$ & psig. & $\begin{array}{l}2250 \\
2265\end{array}$ & min. & $\begin{array}{l}1427 \\
1427\end{array}$ & psig. \\
\hline $30 "$ & 1618 & $"$ & 780 & $"$ & 1480 & $"$ & 1530 & $"$ & 1450 & $" 1$ & & & & \\
\hline 45 & 1607 & $"$ & 795 & " & 1479 & " & 1545 & $"$ & 1450 & $"$ & & & & \\
\hline 60 & 1597 & $"$ & 810 & ". & 1479 & " & 1560 & $"$ & 1450 & " & & & & \\
\hline 75 & 1592 & $"$ & 825 & " & 1478 & " & 1575 & $"$ & 1450 & " & & & & \\
\hline 90 & 1584 & $"$ & 840 & " & 1478 & " & 1590 & $"$ & 1449: & $"$ & & & & \\
\hline 105 & 1576 & $"$ & 855 & " & 1478 & $"$ & 1605 & " & 1449 & $"$ & & & & \\
\hline 120 & 1571 & $"$ & 870 & " & 1477 & " & 1620 & $"$ & 1448 & $"$. & & & & \\
\hline 135 & 1568 & $"$ & 885 & " & 1477 & $"$ & 1635 & $"$ & 1448 & " & & & & \\
\hline 150 & 1563 & " & 900 & " & 1476 & $"$ & 1650 & " & 1447 & " & & & & \\
\hline 165 & 1556 & $"$ & 915 & " & 1476 & $"$ & 1665 & " & 1447 & $"$ & & & & \\
\hline 180 & 1555 & $"$ & 930 & $"$ & 1476 & $"$ & 1680 . & " & 1446 & " & & & & \\
\hline 195 & 1552 & $"$ & 945 & $"$ & 1475 & $"$ & 1695 & $"$ & 1446 & $"$ & & & & \\
\hline 210 & 1550 & $"$ & 960 & '" & 1475 & $"$ & 1710 & $"$ & 1445 & $"$ & & & & \\
\hline 225 & 1545 & 11 & 975 & $"$ & 1475 & $"$ & 1725 & " & 1445 & $"$ & & & & \\
\hline 240 & 1542 & $"$ & 990 & $"$ & 1474 & $"$ & 1740 & $"$ & 1444 & $"$ & & & & \\
\hline 255 & 1539 & " ' & 1005 & $"$ & 1474 & $"$ & 1755 & $"$ & 1443 & $"$ & & & & \\
\hline 270 & 1537 & $"$ & 1020 & $"$ & 1474 & $"$ & 1770 & $"$ & 1442 & $"$ & & & & \\
\hline 285 & .1534 & $"$ & 1035 & "i & 1473 & $"$ & 1785 & $"$ & 1442. & $"$ & & & & $\because$ \\
\hline 300 & 1529 & $"$ & 1050 & $"$ & 1473 & $"$ & 1800 & $"$ & 1441 & $"$ & & & & \\
\hline 315 & 1526 & $"$ & 1065 & $"$ & 1472 & $"$ & 1815 & $"$ & 1440 & $"$ & & & & \\
\hline 330 & 1526 & $"$ & 1080 & $"$ & 1472 & $"$. & 1830 & $"$ & 1439 & $"$ & & & & \\
\hline 345 & 1526 & $"$ & 1095 & $"$. & 1472 & ii & 1845 & $"$ & 1430 & $"$ & & & & \\
\hline 360 & $1526^{\circ}$ & $"$ & 1110 & " & 1471 & $"$ & 1860 & $"$ & 1437 & " & & & & \\
\hline 375 & 1525 & $"$ & 1125 & $"$ & 1471 & $"$ & 1875 & $"$ & 1436 & $"$ & & & & \\
\hline 390 & 1525 & $"$ & 1140 & " & 1471 & $"$ & 1890 & $"$ & 1436 & $"$ & & & & \\
\hline 405 & 1525 & $"$ & 1155 & " & 1470 & " & 1905 & " & 1435 & $"$ & & & & \\
\hline 420 & 1525 & $"$ & 1170 & " & 1469 & " & 1920 & $"$ & 1435 & $"$ & & & & \\
\hline 435 & 1524 & $"$ & 1185 & " & 1467 & $"$ & 1935 & $"$ & 1434 & $"$ & & & & \\
\hline 450 & 1524 & $"$ & 1200 & " & 1466 & $"$ & 1950 & $"$ & 1433 & $"$ & & & & \\
\hline 465 & 1523 & $"$ & 1215 & " & 1465 & $"$ & 1965 & $"$ & 1433 & $"$ & & & . & \\
\hline 480 & 1519 & $"$ & 1230 & " & 1463 & $"$ & 1980 & $"$ & 1432 & $"$ & & & , & \\
\hline 495 & 1518 & $"$ & 1245 & " & 1462 & $"$ & 1995. & $"$ & 1432 & $"$. & & & & \\
\hline 510 & 1517 & $"$ & 1260 & $"$ & 1460 & " & 2010 & " & 1431 & $"$ & & & & \\
\hline 525 & 1514 & " & 1275 & " & 1458 & $"$ & 2025 & $"$ & 1430 & " & & & & \\
\hline 540 & 1511 & $"$ & 1290 & " & 1457 & " & 2040 & " & $1429^{\circ}$ & $"$ & & & & \\
\hline 555 & 1508 & " & 1305 & " & 1456 & $"$ & 2055 & $"$ & 1429 & " & & & & \\
\hline 570 & 1505 & $"$ & 1320 & $"$ & 1455 & $"$ & 2070 & " & 1429 & " & & & & \\
\hline 585 & 1502 & " & 1335 & " & 1454 & " & 2085 & " & 1428 & " & & & & \\
\hline 600 & 1499 & $"$ & 1350 & " & 1453 & " & 2100 & " & 1428 & " & & & & \\
\hline 615 & 1496 & " & 1365 & " & 1450 & " & 2115 & $"$ & 1428 & " & & & & \\
\hline 630 & 1493 & " & 1380 & " & 1450 & $"$ & 2130 & " & 1428 & " & & & & \\
\hline 645 & 1491 & " & 1395 & " & 1450 & $"$ & 2145 & " & 1428 & " & & & & \\
\hline 660 & 1489 & " & 1410 & " & 1450 & $"$ & 2160 & " & 1427 & " & & & & \\
\hline 675 & 1486 & " & 1425 & " & 1450 & $"$ & 2175 & $"$ & 1427 & " & & & & \\
\hline 690 & 1484 & $"$ & 1440 & " & 1450 & $"$ & 2190 & " & 1427 & $"$ & & & & \\
\hline 705 & 1483 & $"$ & 1455 & " & 1450 & $"$ & 2205 & " & 1427 & $"$ & & & & \\
\hline$"$ & 1482 & " & 1470 & $"$ & 1450 & $"$ & 2220 & " & 1427 & $"$ & & & & \\
\hline 735." & 1481 & " & 1485 & $"$ & 1450 & $"$ & 2235 & " & 1427 & & & & & \\
\hline
\end{tabular}




\section{TEST 1-6}

Water Pressurês Between Packers*

Time (Min)

0

15

60

95

260

515

2190
PSIG

1859

1609

1570

1541

1504

1466

1440

*Electric tape measurement. 
RHO-BWI-ST-1

TEST 1-7 


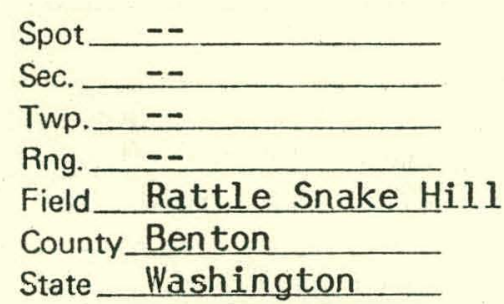

Csg. Size \& Grade $\frac{13 \text { 3/8" }}{27 / 8^{\prime \prime} 6.5 \text { 非 }}$
Tubing Size
Tool Depth $\frac{1650-1780^{\prime}}{--}$
On Location @
Off Location @ $\frac{--}{\text { Stan Anama }}$
Lynes Rep.
Well Owners Rep. Paul Eddy

Tool Description Treating \& Testing Tool

Packer size $73 / 8^{\prime \prime} \times 66^{\prime \prime}$

P0非 WTC-SBB-39166

Summary: $\quad$ Test 非

$5-10-77$

$1: 15$ PM.

Packers in place, filled tubing and inflated packers with 500 psig surface pressure.

$2: 05$ PM.

Moved tool to between position and began swabbing.

3:30 PM. Swabbed down. Left open for 980 minutes.

$5-11-77$

$7: 30$ AM.

Ran swab for recovery. Recovered 30 gallons per swab, approximately 360 gallons per hour.

Flowing pressures in 15 minute increments on following pages. 


\section{LYNES, INC.}

Operator Arco Hanford Co.

Lease \& No. RSH 非1

DST No.

7

Above Interval

PRD Make Kuster K-3

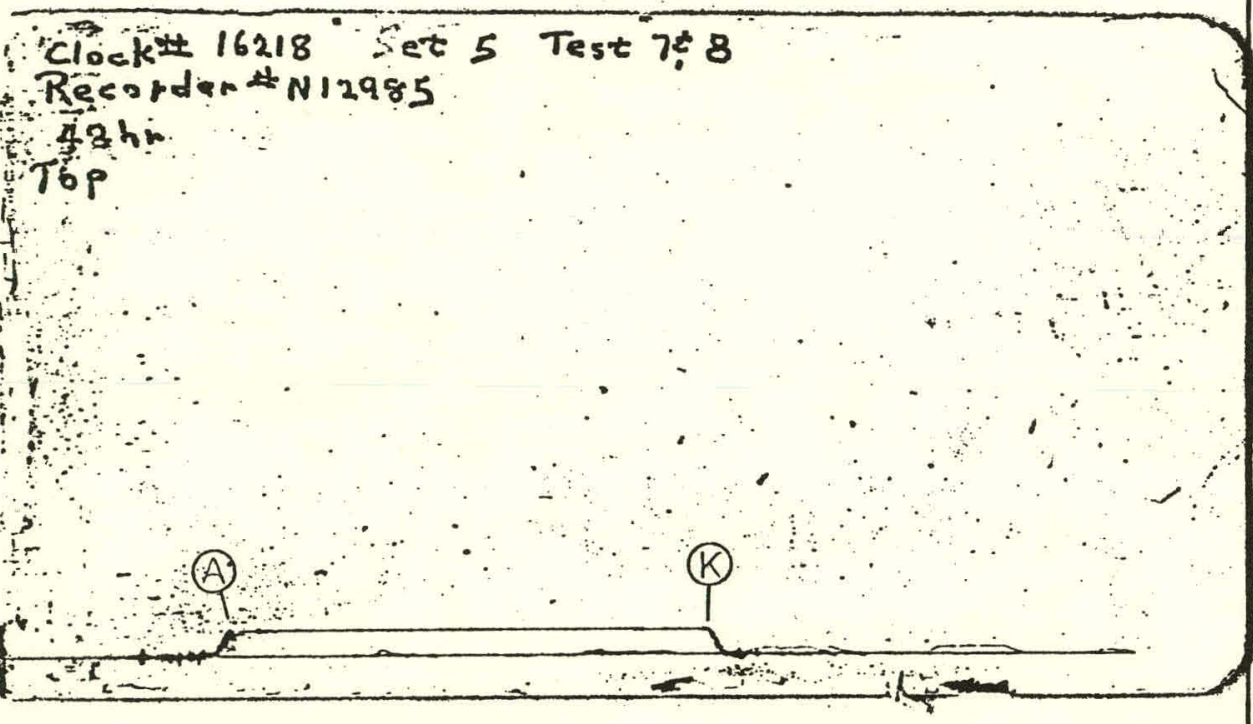

Between Interval

Clock 16239 Set 5 Test $7 \% 8$
Recordar 15719

Berwean

if

$1 ?$

is

$\underbrace{A}_{i \rightarrow \infty}$ (B) C
Pressure Below Bottom

Packer Bled To
No. $\frac{12985}{\text { Press }}$ Cap. $.6100 @ \frac{1633^{\prime}}{\text { Corrected }}$

Initial Hydrostatic A 251

\begin{tabular}{ll|l} 
Final Hydrostatic & $\mathrm{K}$ & 251
\end{tabular}

Initial Flow

Final Initial Flow

Initial Shut-in

Second Initial Flow

Second Final Flow

Second Shut-in

Third Initial Flow

Third Final Flow

Third Shut-in

B

B $\quad--$

C $\quad--$

D

F

G

H

I

$\frac{\mathrm{H}}{\mathrm{I}}$

PRD Make Kuster K-3
No. 15714 Cap. 6000

No. 15714

Cap. 6000

Initial Hydrostatic

Final Hydrostatic

Initial Flow

Final Initial Flow

Initial Shut-in

Second Initial Flow Second Final Flow

Second Shut-in

Third Initial Flow

Third Final Flow

Third Shut-in

A

A 268

268

\begin{tabular}{l|l}
$\mathrm{K}$ & 283 \\
\hline
\end{tabular}

B 114

C

268

\begin{tabular}{l|c} 
D & 268 \\
\hline E & --
\end{tabular}

F

G

H

$--$

@ $1662^{\prime}$

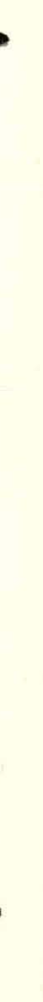

Pressure Below Bottom

Packer Bled To 


\section{LYNES, INC.}

Operator Arco Hanford Co. Lease \& No.

RSH- 非 1 UsT No. 7

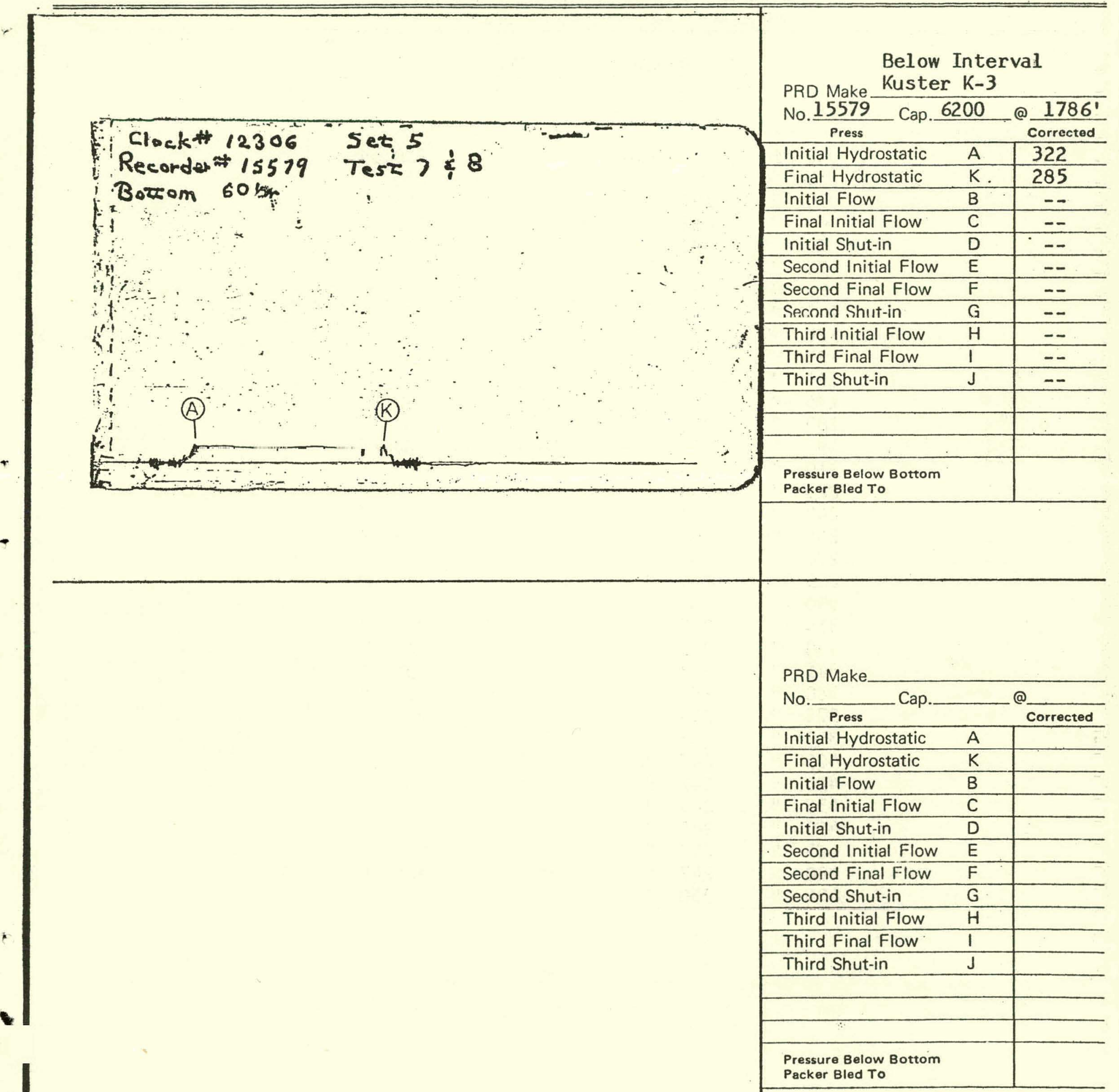


LYNES, INC.

Operator Arco Hanford Co. Lease \& No.

RSH. 非 DST No. 7

Recorder No. 15714

\begin{tabular}{|c|c|c|c|c|c|c|c|}
\hline 0 & $\min$. & 114 & psig. & 510 & min. & 250 & psig. \\
\hline 15 & $"$ & 184 & & 525 & $"$ & 250 & $"$ \\
\hline 30 & $"$ & 199 & $"$ & 540 & $"$ & 253 & $"$ \\
\hline 45 & $"$ & 212 & $"$ & 555 & $"$ & 253 & $"$ \\
\hline 60 & $"$ & 222 & " & 570 & $"$ & 253 & $"$ \\
\hline 75 & $"$ & 227 & $"$ & 585 & " & 255 & $"$ \\
\hline 90 & $"$ & 232 & $"$ & 600 & $"$ & 258 & $"$ \\
\hline 105 & $"$ & 232 & " & 615 & " & 259 & " \\
\hline 120 & $"$ & 237 & $"$ & 630 & $"$ & 260 & $"$ \\
\hline 135 & $"$ & 240 & $"$ & 645 & $"$ & 261 & " \\
\hline 150 & " & 242 & $"$ & 660 & $"$ & 263 & " \\
\hline 165 & " & 242 & $"$ & 675 & " & 263 & " \\
\hline 180 & $"$ & 247 & $"$ & 690 & $"$ & 263 & " \\
\hline 195 & " & 210 & " & 705 & " & 263 & " \\
\hline 210 & " & 253 & " & 720 & " & 264 & $"$ \\
\hline 225 & " & 258 & " & 735 & " & 265 & " \\
\hline 240 & " & 263 & $"$ & 750 & " & 268 & $"$ \\
\hline 255 & " & 263 & " & 765 & " & 268 & " \\
\hline 270 & " & 263 & " & 780 & " & 268 & " \\
\hline 285 & " & 264 & " & 793 & " & 268 & " \\
\hline 300 & " & 263 & " & 810 & " & 268 & " \\
\hline 315 & " & 265 & " & 825 & " & 263 & " \\
\hline 330 & " & 265 & " & 840 & " & 260 & $"$ \\
\hline 345 & " & 263 & " & 855 & " & 255 & " \\
\hline 360 & " & 260 & " & 870 & " & 253 & " \\
\hline 375 & " & 258 & " & 885 & " & 253 & $"$ \\
\hline 390 & " & 253 & " & 900 & " & 253 & " \\
\hline 405 & " & 247 & " & 915 & " & 253 & " \\
\hline 420 & " & 247 & " & 930 & " & 253 & " \\
\hline 435 & ". & 245 & " & 945 & " & 253 & " \\
\hline 450 & " & 245 & " & 960 & " & 256 & " \\
\hline 465 & " & 247 & " & 975 & $"$ & 263 & " \\
\hline 480 & " & 247 & " & 980 & " & 268 & " \\
\hline 495 & " & 250 & " & & & & \\
\hline
\end{tabular}


TEST 1-8 


Spot --
Sec.
Twp. --
Rng.
Field Rattle Snake Hill
County Benton
State Washington

Csg. Size \& Grade $\frac{133 / 8^{\prime \prime}}{27 / 8^{\prime \prime} 6.5 \text { 非 }}$
Tubing Size $\frac{2178-2860^{\prime}}{\text { Tool Depth }}$
On Location @ $\frac{--}{--}$
Off Location @ $\frac{\text { Stan Anama }}{\text { Lynes Rep. }}$
Well Owners Rep. Paul Eddy

Tool Description_Treating \& Testing Tool

Packer size $73 / 8^{\prime \prime} \times 66^{\prime \prime}$

PO\# WTC-SBB-39166

Summary:

Test \# 8

5-11-77

8:50 AM. Filled tubing and moved tool to below position. Began swabbing.

9:19 AM. Swabbed down. Left open for 116 minutes.

11:15 AM. Ran swab to check recovery. 1st run recovered 50 gallons, 2nd run recovered 55 gallons.

11:27 AM. Equalized and released packers.

Flowing pressures in 15 minute increments on following pages. 


\section{LYNES, INC.}

Operator Arco Hanford Co.

Lease \& No.

RSH 非1

DST No. 8

Clock $162.18 \cdot 5 e t 5$ Test $7 \div 8$

Recorder $N 12985$

48 hr

Top

s.

$\therefore$

$+\cdots$

in

.

3

P A

$6+1$
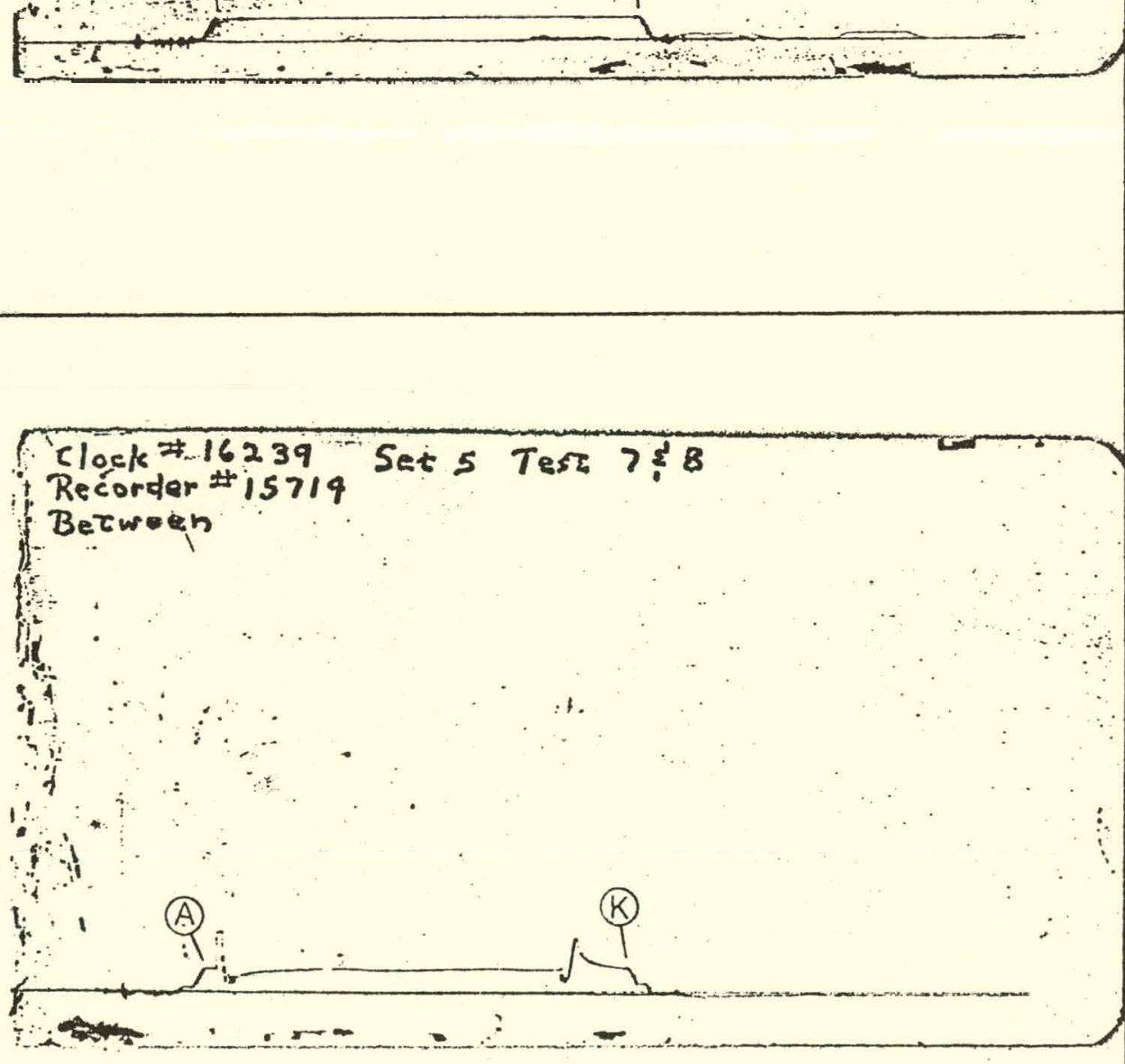

Above Interval

PRD Make Kuster K-3

No. 12985 Cap.6100@ 1763'

Initial Hydrostatic

Final Hydrostatic

Initial Flow

Final Initial Flow

Initial Shut-in

Second Initial Flow

Second Final Flow

Second Shut in

Third Initial Flow

Third Final Flow

Third Shut-in

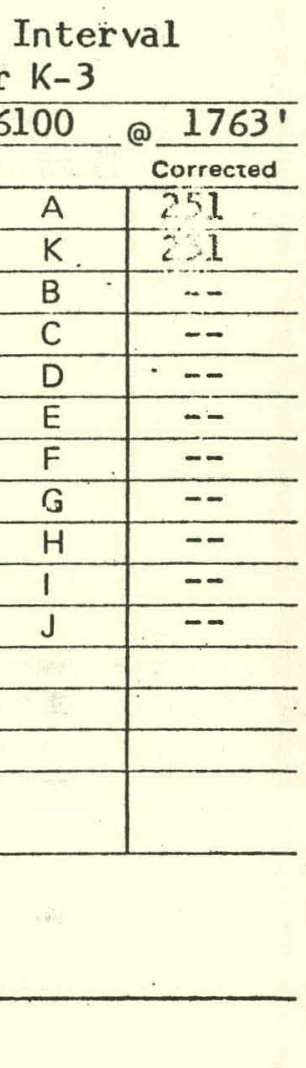

Pressure Below Bottom

Packer Bled To

Between Interval

PRD Make Kuster K-3

No. 15714 Cap. 6000 @ 1792

\begin{tabular}{ll|l} 
Initial Hydrostatic & A & 268
\end{tabular}

\begin{tabular}{ll|l} 
Final Hydrostatic & K & 283
\end{tabular}

Initial Flow

Final Initial Flow

Initial Shut-in

Second Initial Flow

Second Final Flow

Second Shut-in

Third Initial Flow

Third Final Flow

Third Shut-in

\begin{tabular}{l|l}
$\mathrm{B}$ & -- \\
$\mathrm{C}$ & --
\end{tabular}

D

E

F




\section{LYNES, INC.}

Operator Arco Hanford Co.

Lease \& No.

RSH 非1

DST No._ 8

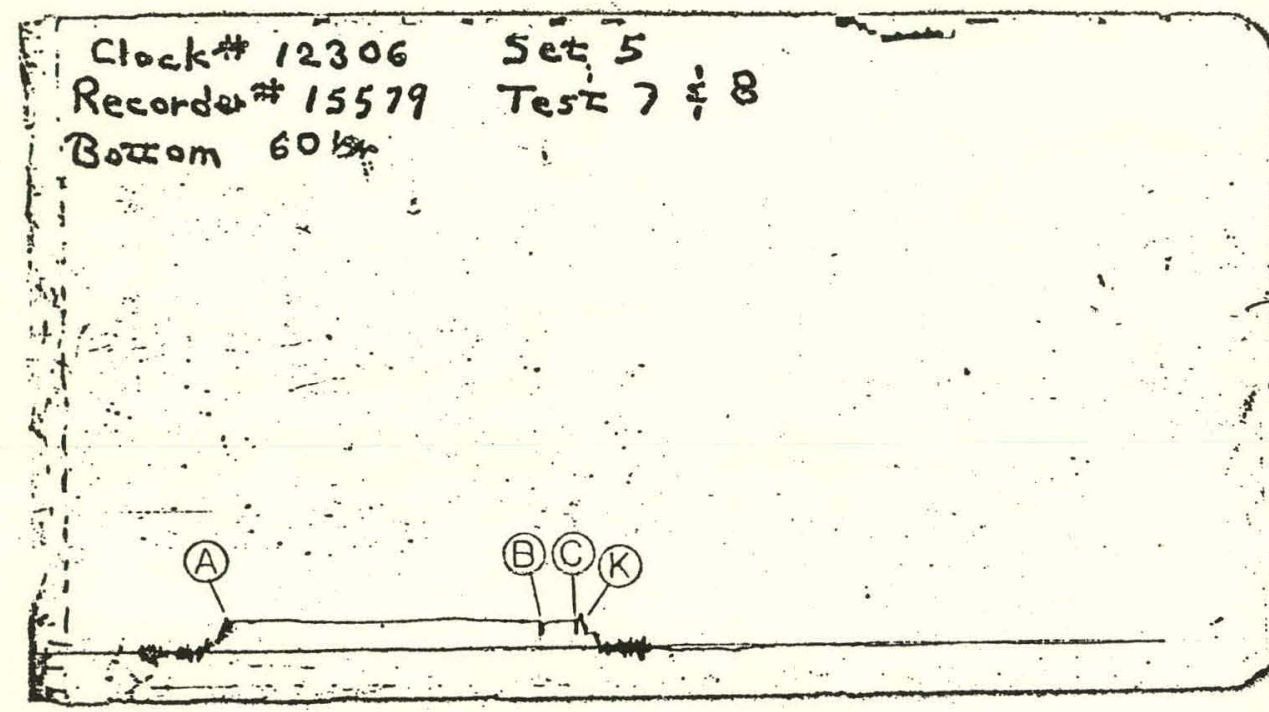

Below Interval

PRD Make Kuster K-3

No. 15579 Cap. $6200 @ 2866^{\prime}$

Press Corrected

Initial Hydrostatic A 1322

Final Hydrostatic $\mathrm{K} \quad 285$

\begin{tabular}{ll|l} 
Initial Flow & B & 141
\end{tabular}

Final Initial Flow

Initial Shut-in

Second Initial Flow

Second Final Flow

Second Shut-in

Third Initial Flow

Third Final Flow

Third Shut-in

C 288

D

E

F

G

H

$-$

$\mathrm{J}$

-

Pressure Below Bottom

Packer Bled To

PRD Make

\begin{tabular}{|c|c|c|}
\hline No.__ Cap. & 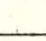 & \\
\hline Press & & Corrected \\
\hline Initial Hydrostatic & A & \\
\hline Final Hydrostatic & $K$ & \\
\hline Initial Flow & $B$ & \\
\hline Final Initial Flow & $\mathrm{C}$ & \\
\hline Initial Shut-in & D & \\
\hline Second Initial Flơvv & $E$ & \\
\hline Second Final Flow & $\mathrm{F}$ & \\
\hline Second Shut-in & $\mathrm{G}$ & \\
\hline Third Initial Flow & $\mathrm{H}$ & \\
\hline Third Final Flow & 1 & \\
\hline Third Shut-in & $J$ & \\
\hline & & \\
\hline & & \\
\hline $\begin{array}{l}\text { Pressure Below Bottom } \\
\text { Packer Bled To }\end{array}$ & & \\
\hline
\end{tabular}




\section{LYNES, INC.}

Operator Arco Hanford Co. Lease \& No.

RSH 非 DST No. 8

Recorder No. 15579

$\begin{array}{rlll}0 & \text { min. } & 141 & \text { psig. } \\ 15 & " & 262 & " \\ 30 & " & 275 & " \\ 45 & " & 277 & " \\ 60 & " & 280 & " \\ 75 & " & 283 & " \\ 90 & " & 284 & " \\ 105 & " & 106 & " \\ 116 & \text { " } & 288\end{array}$


TEST 2-1 


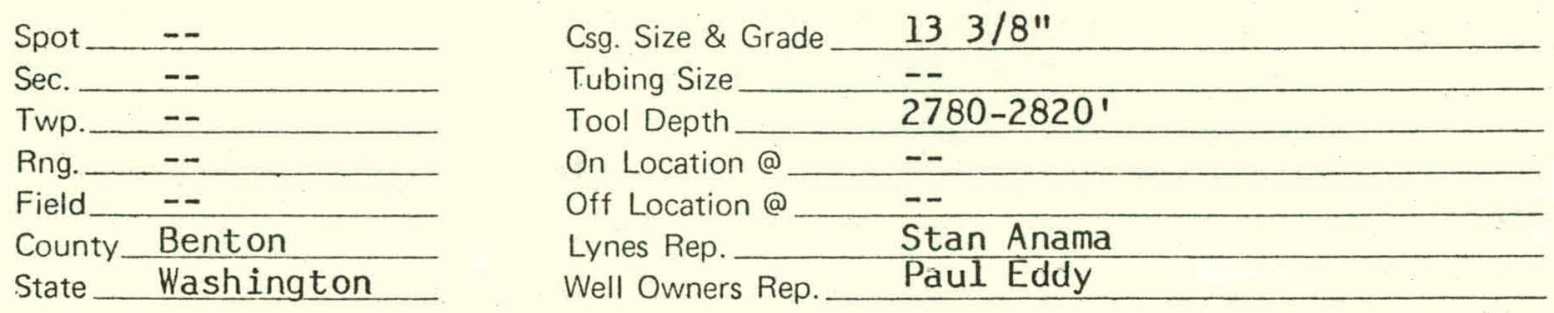

Tool Description_5"-Treating \& Testing Tool

\section{Test 非 1}

Summary:

$9-30-77$

7:30 PM. Set tool in place.

7:31 PM. Began filling tubing.

9:00 PM. Tubing full. Inflated packers with 437 psig. static and 800 psig surface pressure.

9:30 PM. Moved to between position.

9:54 PM. Began monitering fluid level with iron horse.

$10-1-77$

Monitered water level in tubing for 24 hours.

$10-2-77$

9:37 AM. Monitered water level in tubing.

9:47 AM. Filled tubing to surface.

10:00 AM. Moved to equalize.

10:15 AM. Deflated packers and tripped out of hole.

4:00 PM. Tools out of hole. Ran iron horse in to get static fluid level, found level at 1012.5'. 


\section{LYNES, INC.}

Operator_Hydrologic Testing Operations Lease \& No. RSH \# I

Below

PRD Make Kuster $\mathrm{K}-3$

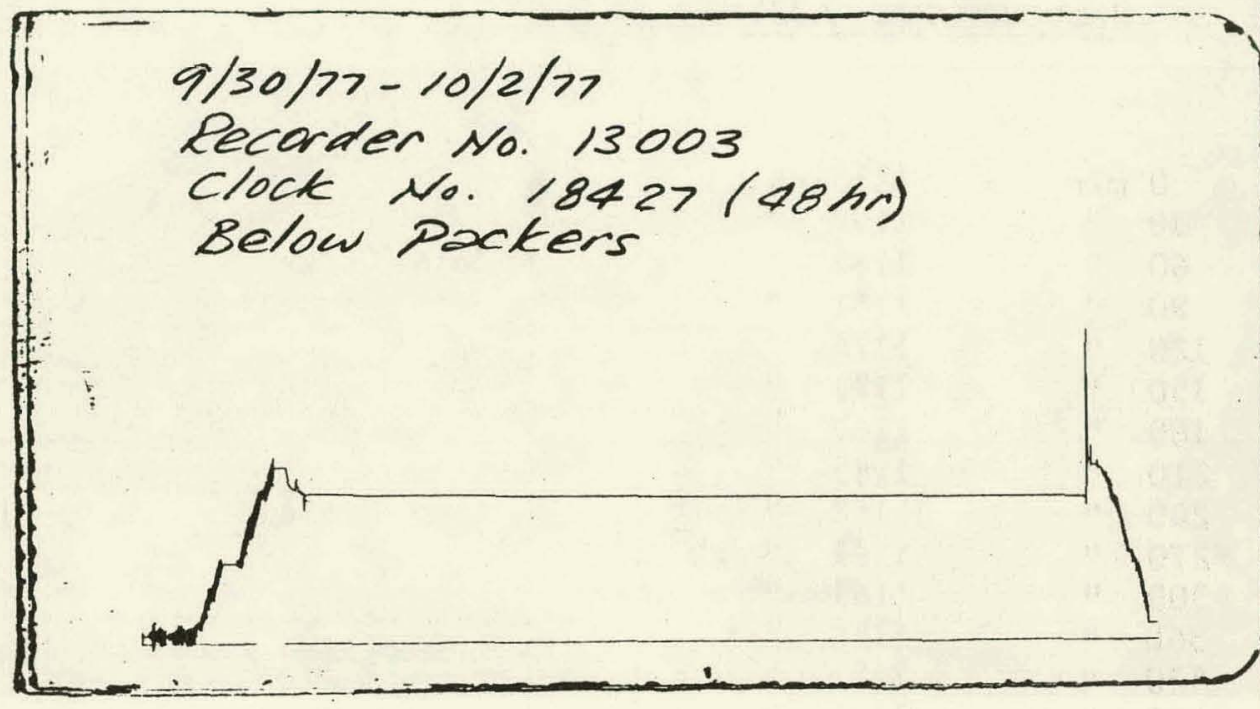

No 13003 Cap 2900 Press

DST No.

$-$

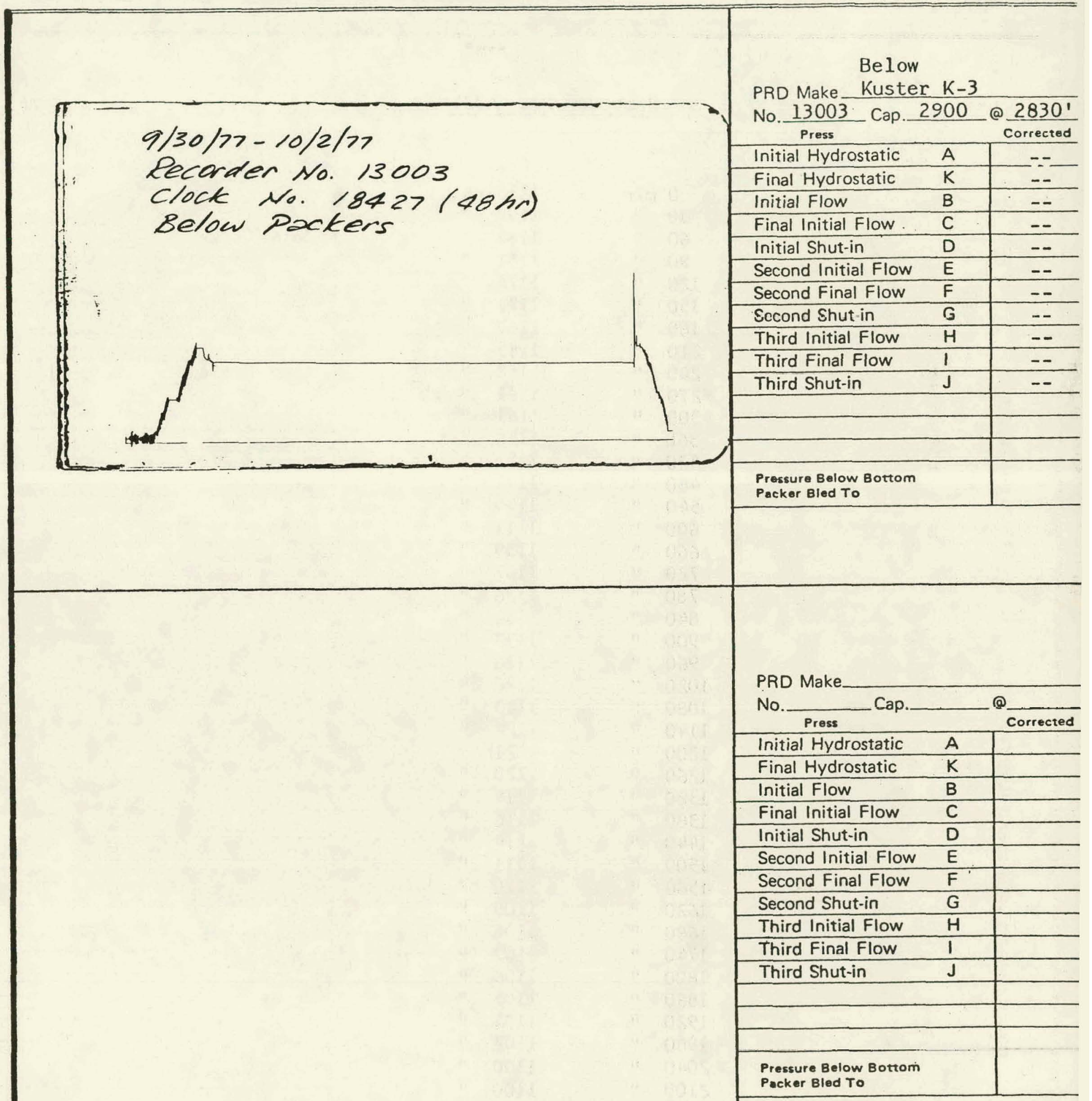




\section{LYNES, INC.}

Operator Rockwell Hanford Operations Lease \& No. RSH \#1 DST No. --

\section{Recorder No. 14325}

\begin{tabular}{|c|c|c|c|}
\hline \multicolumn{2}{|c|}{0 min. } & \multirow{2}{*}{\multicolumn{2}{|c|}{1218 psig. }} \\
\hline 30 & $"$ & & \\
\hline 60 & " & 1187 & \\
\hline 90 & $"$ & 1181 & $"$ \\
\hline 120 & " & 1176 & $"$ \\
\hline 150 & " & 1171 & $"$ \\
\hline 180 & " & 1167 & \\
\hline 210 & " & 1165 & $"$ \\
\hline 240 & $"$ & 1163 & $"$ \\
\hline 270 & " & 1161 & \\
\hline 300 & " & 1161 & $"$ \\
\hline 360 & " & 1156 & $"$ \\
\hline 420 & $"$ & 1153 & $"$ \\
\hline 480 & $"$ & 1147 & $"$ \\
\hline 540 & " & 1144 & " \\
\hline 600 & " & 1141 & " \\
\hline 660 & $"$ & 1139 & $"$ \\
\hline 720 & " & 1137 & $"$ \\
\hline 780 & $"$ & 1136 & $"$ \\
\hline 840 & " & 1134 & $"$ \\
\hline 900 & $"$ & 1132 & $"$ \\
\hline 960 & " & 1128 & $"$ \\
\hline 1020 & " & 1126 & $"$ \\
\hline 1080 & $"$ & 1123 & $"$ \\
\hline 1140 & " & 1122 & " \\
\hline 1200 & " & 1121 & " \\
\hline 1260 & $"$ & 1120 & " \\
\hline 1320 & " & 1119 & " \\
\hline 1380 & $"$ & 1116 & $"$ \\
\hline 1440 & $"$ & 1114 & " \\
\hline 1500 & $"$ & 1111 & " \\
\hline 1560 & " & 1110 & " \\
\hline 1620 & $"$ & 1109 & " \\
\hline 1680 & $"$ & 1108 & " \\
\hline 1740 & " & 1107 & " \\
\hline 1800 & " & 1106 & $"$ \\
\hline 1860 & " & 1105 & " \\
\hline 1920 & " & 1104 & $"$ \\
\hline 1980 & $"$ & 1102 & " \\
\hline 2040 & " & 1100 & $"$ \\
\hline 2100 & $"$ & 1100 & $"$ \\
\hline 2160 & " & 1099 & $"$ \\
\hline 2177 & " & 1099 & " \\
\hline
\end{tabular}


TEST 2-1

Water Pressures Between Packers*

\begin{tabular}{ll} 
Time (Min) & PSIG \\
\hline & \\
0 & 1218 \\
30 & 1209 \\
45 & 1203 \\
60 & 1199 \\
90 & 1192 \\
120 & 1187 \\
150 & 1183 \\
180 & 1179 \\
240 & 1174 \\
300 & 1170 \\
600 & 1152 \\
900 & 1140 \\
1080 & 1134 \\
1110 & 1133 \\
1350 & 1127 \\
1590 & 1120 \\
1830 & 1114 \\
2070 & 1112 \\
2160 & 1108
\end{tabular}

*Electric tape measurement. 
TEST 2-2 
Phone

522-1206 Area 303
LYNES, INC.

$133 / 8^{\prime \prime}$

Csg. Size \& Grade

--

Tubing Size

Tool Depth

On Location@

Off Location@

Lynes Rep.

Well Owners Rep.

$2717-2739$

$7: 30$ AM. $\quad 10-3-77$

9:00 AM. 10-5-77

Stan Anama

Paul Eddy

$\begin{array}{ll}\text { County } & \text { Benton } \\ \text { State } & \text { Washington }\end{array}$

Tool Description_ 5." Treating \& Testing Tool

\section{Test 非2}

Summary:

$10-3-77$

12:00 Set tool in place.

12:04 PM. Began filling tubing.

1:05 PM. Tubing full. Inflated packers with 433 psig. static and 600 psig. surface pressure.

1:32 PM. Moved to between position. Applied 570 psig. Pressure bled to zero. Rigged gauge and tubing head and applied 1000 psig. Monitered gauge pressure.

\section{$10-4-77$}

8:40 AM. Monitered surface pressure at gauge, pressure to zero. Monitered fluid level for 24 hours.

$10-5-77$

$8: 40$ AM. Moved to equalize for 5 minutes.

8:47 AM. Deflated packers and tripped out of hole.

3:30 PM. Tools out of hole. Found fluid level at 1010.5!. 


\section{LYNES, INC.}

Operator Rockwell Hanford Operations Lease \& No. RSH \#1

DST No._- - -
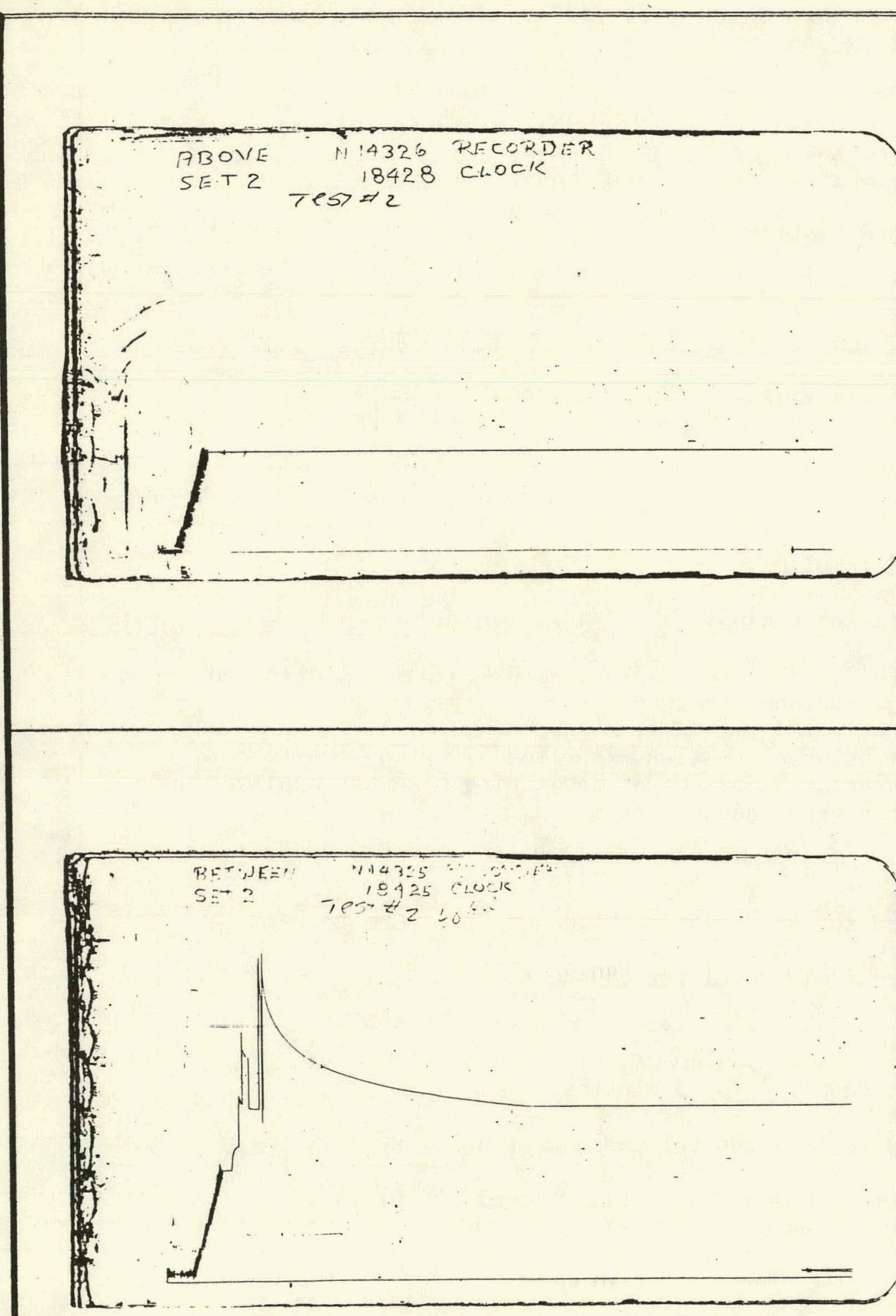

\begin{tabular}{|c|c|c|}
\hline $\begin{array}{ll}\text { Pro Make } & \begin{array}{l}\text { Above } \\
\text { Kuste }\end{array} \\
\text { No, } 14326 \quad \text { Cap }\end{array}$ & $\frac{k-3}{900}$ & $2702^{\prime}$ \\
\hline Press & & Corrected \\
\hline Initial Hydrostatic & A & 744 \\
\hline Final Hydrostatic & $\bar{K}$ & -- \\
\hline Initial Flow & B & - \\
\hline Final luilial Fluw & r. & 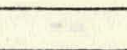 \\
\hline Initial Shut-in & D & -- \\
\hline Second Initial Flow & $\bar{E}$ & -- \\
\hline Second Final Flow & $F$ & - \\
\hline Second Shut-in & G & -- \\
\hline Third Initial Flow & $\mathrm{H}$ & -- \\
\hline Third Final Flow & 1 & -- \\
\hline Third Shut-in & $\mathrm{J}$ & -- \\
\hline & & \\
\hline & & \\
\hline $\begin{array}{l}\text { Pressure Below Bottom } \\
\text { Packer Bled To }\end{array}$ & & \\
\hline
\end{tabular}

Between

PRD Make Kuster $\mathrm{K}-3$

No. 14325 Cap. 2900 @_27281 Press Corrected Initial Hydrostatic Final Hydrostatic Initial Flow Final Initial Flow Initial Shut-in Secund Initial Flow Second Final Flow Second Shut-in Third Initial Flow Third Final Flow Third Shut-in

\begin{tabular}{|l|l}
\hline & \\
\hline & \\
\hline & \\
\hline $\begin{array}{l}\text { Pressure Below Bottom } \\
\text { Packer Bled To }\end{array}$ & \\
\hline
\end{tabular}




\section{LYNES, INC.}

$c$

Operator_Rockwell Hanford Operations Lease \& No. RSH \#l

DST No.

$-$

c.

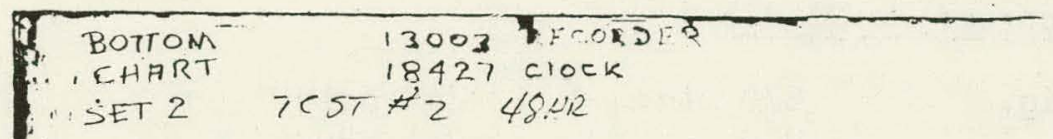

Below

PRD Make Kuster K-3

No. $\frac{13003}{\text { Press }}$ Cap. $2900 @ \frac{2749^{\prime}}{\text { Corrected }}$

Initial Hydrostatic

Final Hydrostatic

Initial Flow

Final Initial Flow

Initial Shut-in

Second Initial Flow

Second Final Flow

Second Shut-in

Third Initial Flow

Third Final Flow

Third Shut-in

\begin{tabular}{c|c} 
A & 768 \\
\hline K & -- \\
\hline B & -- \\
\hline C & -- \\
\hline D & -- \\
\hline E & -- \\
\hline F & -- \\
\hline G & -- \\
\hline H & -- \\
\hline I & -- \\
\hline J & -- \\
\hline & \\
\hline
\end{tabular}

Pressure Below Bottom

Packer Bled To

\begin{tabular}{|c|c|c|}
\hline \multirow{2}{*}{\multicolumn{3}{|c|}{ No. $\frac{}{\text { Press }}$ Cap.__ @ $@$}} \\
\hline & & \\
\hline Initial Hydrostatic & A & \\
\hline Final Hydrostatic & $K$ & \\
\hline Initial Flow & B & \\
\hline Final Initial Flow & C & \\
\hline Initial Shut-in & $D$ & \\
\hline Second Initial Flow & $E$ & \\
\hline Second Final Flow & $\mathrm{F}$ & \\
\hline Second Shut-in & G & \\
\hline Third Initial Flow & $\mathrm{H}$ & \\
\hline Third Final Flow & 1 & \\
\hline Third Shut-in & $\mathrm{J}$ & \\
\hline & & \\
\hline & & \\
\hline $\begin{array}{l}\text { Pressure Below Bottom } \\
\text { Packer Bled To }\end{array}$ & & \\
\hline
\end{tabular}




\section{LYNES, INC.}

Operator Rockwell Hanford Operations Lease \& No. RSH 非 I DST No.

\section{Recorder No. 14325}

\begin{tabular}{|c|c|c|c|c|c|c|c|}
\hline 0 & in. & 2197 & psig. & 870 & $\min$. & 1248 & osic \\
\hline 30 & " & 1901 & $"$ & 900 & $"$ & 1241 & 11 \\
\hline 60 & " & 1789 & $"$ & 960 & " & 1227 & $"$ \\
\hline 90 & $"$ & 1710 & " & 1020 & $"$ & 1216 & $"$ \\
\hline 120 & " & 1652 & $"$ & 1080 & $"$ & 1205 & $"$ \\
\hline 150 & " & 1604 & " & 1140 & " & 1199 & $"$ \\
\hline 180 & " & 1566 & $"$ & 1200 & " & 1199 & $"$ \\
\hline 210 & $"$ & 1536 & $"$ & 1260 & $"$ & 1199 & " \\
\hline 240 & $"$ & 1509 & $"$ & 1320 & $"$ & 1199 & " \\
\hline 270 & $"$ & 1484 & " & 1380 & " & 1199 & $"$ \\
\hline 300 & " & 1463 & $"$ & 1440 & $"$ & 1199 & " \\
\hline 330 & " & 1445 & $"$ & 1500 & $"$ & 1199 & $"$ \\
\hline 360 & $"$ & 1428 & $"$ & 1560 & " & 1199 & $"$ \\
\hline 390 & " & 1411 & " & 1620 & " & 1199 & $"$ \\
\hline 420 & $"$ & 1395 & $"$ & 1680 & $"$ & 1199 & $"$ \\
\hline 450 & $"$ & 1390 & $"$ & 1740 & $"$ & 1199 & $"$ \\
\hline 480 & $"$ & 1366 & $"$ & 1800 & " & 1199 & $"$ \\
\hline 510 & " & 1353 & $"$ & 1860 & " & 1199 & $"$ \\
\hline 540 & " & 1341 & $"$ & 1920 & $"$ & 1199 & $"$ \\
\hline 570 & $"$ & 1330 & " & 1980 & " & 1199 & " \\
\hline 600 & " & 1320 & " & 2040 & " & 1199 & " \\
\hline 630 & " & 1312 & " & 2100 & " & 1199 & " \\
\hline 660 & $"$ & 1303 & " & 2160 & " & 1199 & " \\
\hline 690 & " & 1297 & $"$ & 2220 & $"$ & 1199 & " \\
\hline 720 & $"$ & 1287 & $"$ & 2280 & " & 1199 & $"$ \\
\hline 750 & " & 1276 & $"$ & 2340 & " & 1200 & " \\
\hline 780 & $"$ & 1269 & " & 2400 & $"$ & 1202 & $"$ \\
\hline 810 & " & 1263 & $"$ & 2460 & $"$ & 1204 & " \\
\hline 840 & " & 1256 & $"$ & 2464 & 11 & 1204 & " \\
\hline
\end{tabular}




\section{TEST 2-2}

Water Pressures Between Packers*

\section{Time (Min)}

0

15

30

60

120

180

240

370

550

790

1090

1135

1330

1510

2350

2405

2435
PSIG

2186

2116

1976

1834

1683

1586

1518

1426

1346

1266

1206

1186

1186

1185

1184

1184

11.84

*Electric tape measurement. 


\section{TEST 2-3}


Phone

522.1206 Area 303
LYNES, INC.

Box 712 Sterling, Colo.

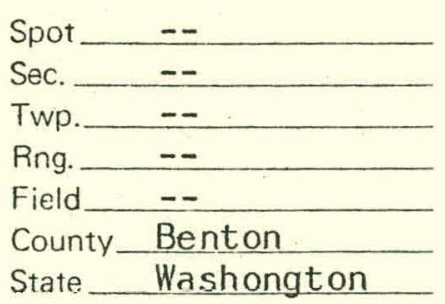

Csg. Size \& Grade $\frac{133 / 4^{\prime \prime}}{--}$
Tubing Size $-\frac{2622-2676^{\prime}}{\text { Tool Depth }}$
On Location @
Off Location @
Lynes Rep.
Well Owners Rep. $\quad$ Paul Eddy

Tool Description 5" Treating \& Testing Tool

Test. 非 3

Summary:

$10-6-77$

8:00 AM. Set tonl in place.

12:00 Began filling tuving.

12:30 PM. Tubing full.

1:30 PM. Inflated packers with 433 psig static and 650 psig surface pressure.

$1: 40$

1:40 PM. Moved tool to between position.

1:42 PM. Monitered gauge pressure. Surface pressure dropped to zero. $10-7-77$

Monitered fluid for 24 hours.

$10-8-77$

8:30 AM. Took last reading. Ran iron horse in annulus, found static fluid level at 1010'.

9:08 AM. Ran iron horse in annulus and found static fluid level at $1010^{\prime}$.

9:12 AM. Moved to equalize position.

1:00 PM. Deflated packers and tripped out of hole. 


\section{LYNES, INC.}

DST No. - -
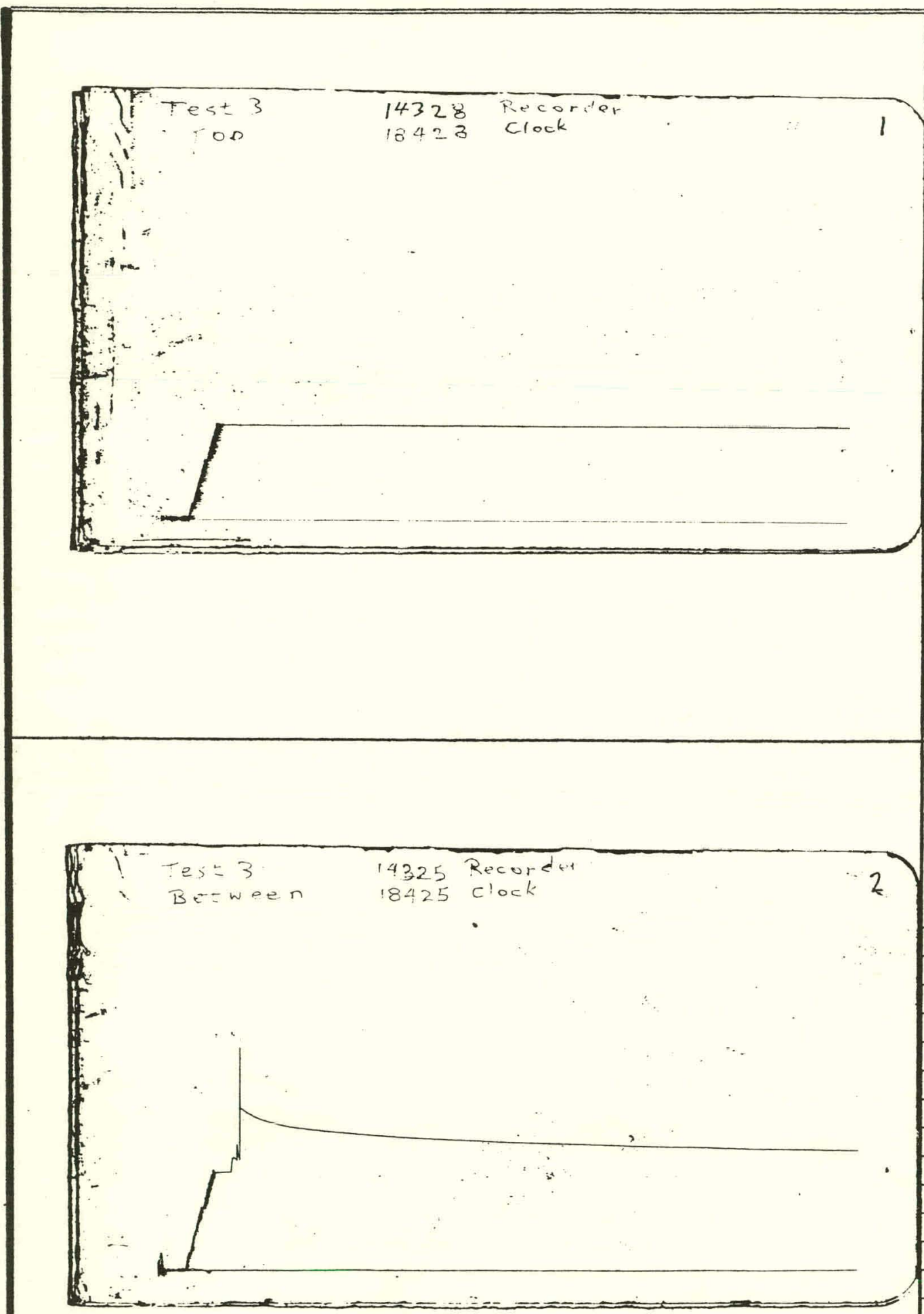

Between

PRD Make Kuster K-3

No. 14325 Cap. $2900 @ 2633^{\prime}$

Press

Above

PRD Make Kuster K-3

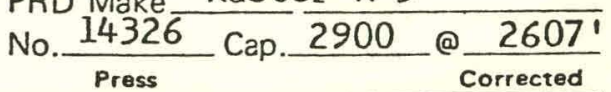

Initial Hydrostatic

\begin{tabular}{c|c} 
A & 694 \\
\hline K & -- \\
\hline B & -- \\
\hline C & -- \\
\hline D & -- \\
\hline E & -- \\
\hline F & -- \\
\hline G & -- \\
\hline$H$ & -- \\
\hline I & -- \\
\hline J & -- \\
\hline & \\
& \\
&
\end{tabular}

Final Hydrostatic

Initial Flow

Final Initial Flow

Initial Shut-In

Second Initial Flow

Second Final Flow

Second Shut-in

Third Initial Flow

Third Final Flow

Third Shut-in

Pressure Below Bottom

Packer Bled To

Initial Hydrostatic

Final Hydrostatic

Initial Flow

Final Initial Flow

Initial Shut-in

Second Initial Flow

Second Final Flow

Second Shut-in

Third Initial Flow

Third Final Flow

Third Shut-in

\begin{tabular}{l|c}
\multicolumn{2}{c}{ Corrected } \\
\hline A & -- \\
\hline$B$ & -- \\
\hline C & -- \\
\hline$D$ & -- \\
\hline$E$ & -- \\
\hline$F$ & -- \\
\hline$G$ & -- \\
\hline$H$ & - \\
\hline I & -- \\
\hline & -- \\
\hline
\end{tabular}

Pressure Below Bottom

Packer Bled To

Clock ran out 2475 minutes into test. 


\section{LYNES, INC.}

$<$

Opera:or Rockwell Hanford Operations Lease \& No. RSH il 1 DST No. $--$

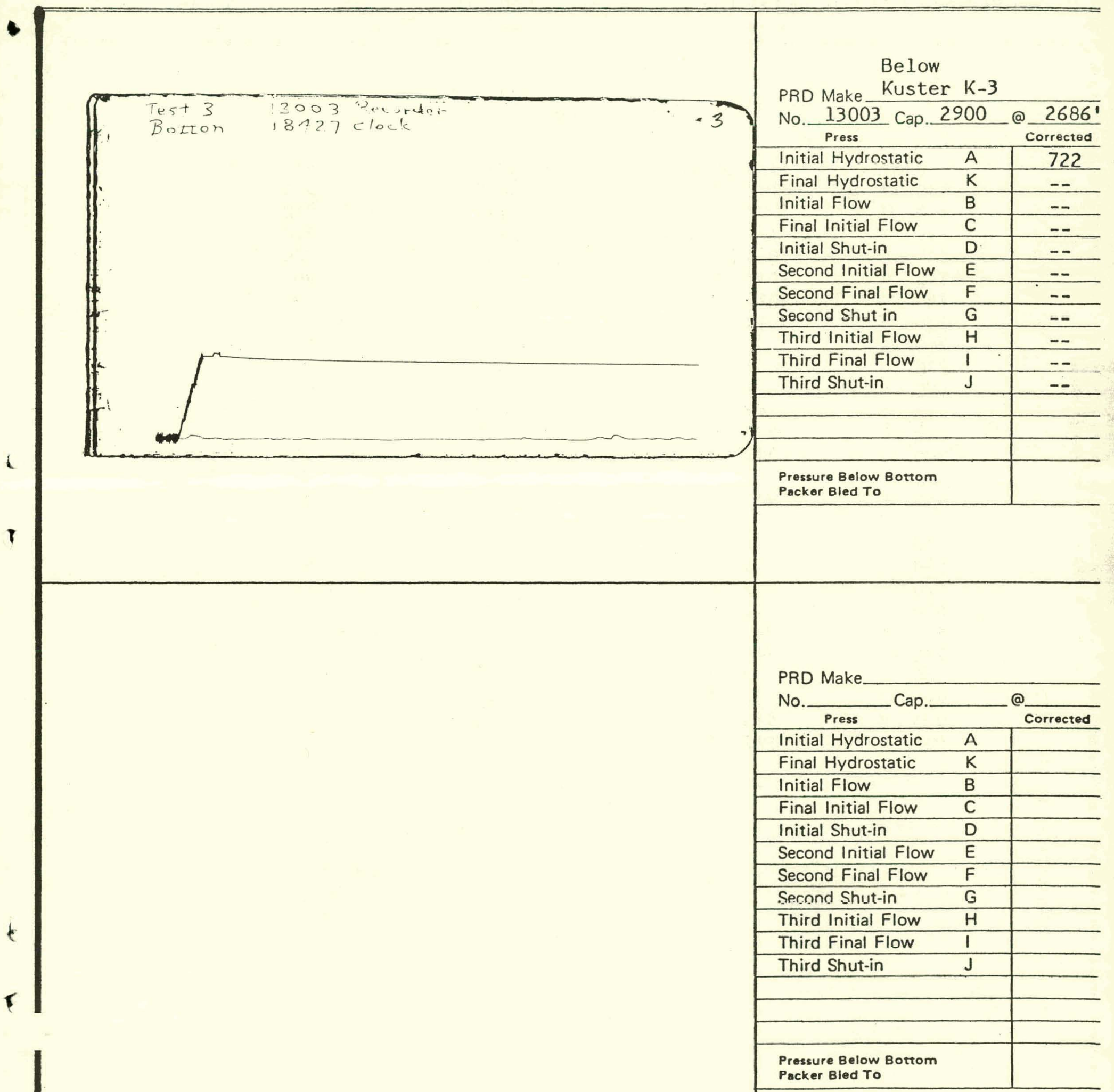




\section{LYNES, INC.}

OperatorRockwell Hanford Operations Lease \& No.

RSH 非 DST No.

Recorder No. 14325

\begin{tabular}{|c|c|c|c|}
\hline 0 & nin. & 1160 & psig \\
\hline 30 & $n$ & 1122 & $"$ \\
\hline 60 & " & 1092 & $"$ \\
\hline 90 & " & 1171 & 11 \\
\hline 120 & $"$ & 1054 & " \\
\hline 150 & $"$ & 1039 & $"$ \\
\hline 180 & " & 1028 & $"$ \\
\hline 210 & " & 1018 & $"$ \\
\hline 240 & $"$ & 1012 & " \\
\hline 270 & " & 1005 & $"$ \\
\hline 300 & " & 1000 & $"$ \\
\hline 330 & $"$ & 993 & $"$ \\
\hline 360 & " & 989 & " \\
\hline 390 & $"$ & 984 & " \\
\hline 420 & " & 979 & " \\
\hline 450 & $"$ & 976 & $"$ \\
\hline 480 & " & 971 & " \\
\hline 510 & " & 967 & " \\
\hline 540 & " & 963 & " \\
\hline 570 & " & 959 & " \\
\hline 600 & " & 955 & " \\
\hline 660 & $"$ & 949 & " \\
\hline 720 & " & 944 & " \\
\hline 780 & " & 939 & " \\
\hline 840 & " & 934 & " \\
\hline 900 & " & 930 & " \\
\hline 960 & " & 927 & " \\
\hline
\end{tabular}

\begin{tabular}{|c|c|c|c|}
\hline 1020 & min. & 921 & psig. \\
\hline 1080 & $"$ & 916 & $"$ \\
\hline 1140 & $" 1$ & 912 & $n$ \\
\hline 1200 & $"$ & 910 & $"$ \\
\hline 1260 & $"$ & 906 & 11 \\
\hline 1320 & $"$ & 904 & $"$ \\
\hline 1380 & $"$ & 900 & " \\
\hline 1440 & $"$ & 896 & $"$ \\
\hline 1500 & $" 1$ & 894 & " \\
\hline 1560 & $"$ & 890 & $"$ \\
\hline 1620 & $"$ & 887 & $"$ \\
\hline 1680 & " & 885 & "1 \\
\hline 1740 & "1 & 883 & " \\
\hline 1800 & $" 1$ & 883 & " \\
\hline 1860 & $"$ & 881 & $"$ \\
\hline 1920 & 11 & 877 & $"$ \\
\hline 1980 & 11 & 874 & " \\
\hline 2040 & "1 & 872 & $"$ \\
\hline 2100 & 11 & 870 & $"$ \\
\hline 2160 & $"$ & 870 & " \\
\hline 2220 & $"$ & 869 & $"$ \\
\hline 2280 & 11 & 867 & $"$ \\
\hline 2340 & 11 & 865 & 11 \\
\hline 2400 & 11 & 861 & " \\
\hline 2460 & 11 & 860 & $"$ \\
\hline 2475 & 11 & 860 & $"$ \\
\hline
\end{tabular}


TEST 2-3

Water Pressures Between Packers*

Time (Min)

PSIG

0

1159

10

1158

30

1154

50

1128

65

1089

125

1080

175

1053

220

1035

400

1023

580

992

820

970

1120

948

1300

927

1480

917

1540

908

2440

873

2500

872

2530

871

*Electric tape measurement. 